
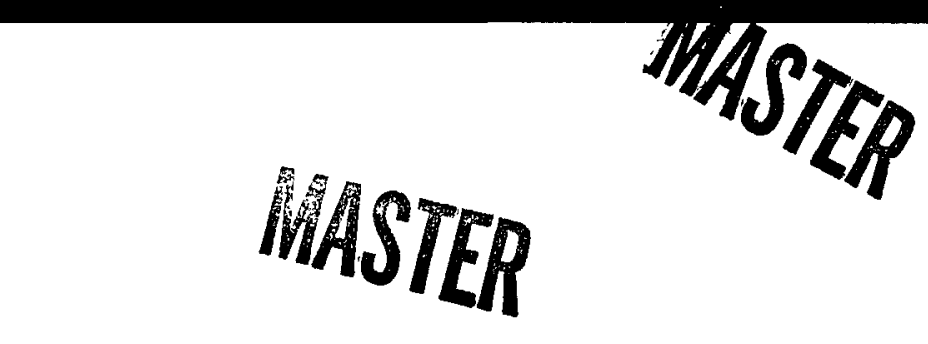

GA-A15030

UC-77

\title{
SOLVENT EXTRACTION \\ IN HTGR REPROCESSING \\ INTERIM DEVELOPMENT REPORT II
}

\author{
Prepared under \\ Contract EY-76-C-03-0167 \\ Project Agreement No. 53 \\ for the San Francisco Operations Office \\ Department of Energy
}

DATE PUBLISHED: JULY 1978

\section{GENERAL ATOMIC COMPANY}


Th1s report was prepared as an account of work sponsored by the United States Government Neither the United States nor the Department of Energy, nor any of their employees, nor any of their contractors, subcontractors, or their employees, makes any warranty, express or implied, or assumes any legal hability or responsibility for the accuracy, completeness or usefulness of any information, apparatus, product or process disclosed, or represents that its use would not infringe privately owned rights

\author{
Printed in the United States of America \\ Available from \\ National Technical Information Service \\ U.S. Department of Commerce \\ 5285 Port Royal Road \\ Springfield, Virginia 22161 \\ Price: Printed Copy $\$ 5.25$; Microfiche $\$ 3.00$ \\ $6 . \ldots$
}




\section{DISCLAIMER}

This report was prepared as an account of work sponsored by an agency of the United States Government. Neither the United States Government nor any agency Thereof, nor any of their employees, makes any warranty, express or implied, or assumes any legal liability or responsibility for the accuracy, completeness, or usefulness of any information, apparatus, product, or process disclosed, or represents that its use would not infringe privately owned rights. Reference herein to any specific commercial product, process, or service by trade name, trademark, manufacturer, or otherwise does not necessarily constitute or imply its endorsement, recommendation, or favoring by the United States Government or any agency thereof. The views and opinions of authors expressed herein do not necessarily state or reflect those of the United States Government or any agency thereof. 


\section{DISCLAIMER}

Portions of this document may be illegible in electronic image products. Images are produced from the best available original document. 


\section{SOLVENT EXTRACTION \\ IN HTGR REPROCESSING \\ INTERIM DEVELOPMENT REPORT II}

WORK DONE BY:

G. E. BENEDICT

D. R. ENGLER

L. E. JOLLEY

G. W. REDDICK

M. D. TRUE

R. G. WILBOURN
PRINCIPAL INVESTIGATOR:

J. J. SHEFCIK

REPORT WRITTEN BY:

R. G. WILBOURN

Prepared under

Contract EY-76-C-03-0167

Project Agreement No. 53

for the San Francisco Operations Office

Department of Energy

GENERAL ATOMIC PROJECT 3261

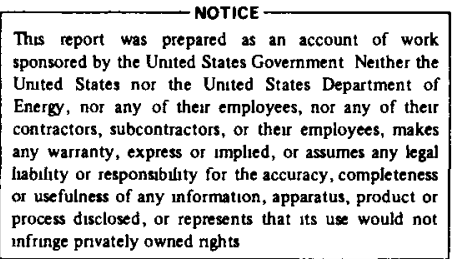

DATE PUBLISHED: JULY 1978

\section{GENERAL ATOMIC COMPANY}




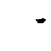




\section{ABSTRACT}

This report contains the findings of a continuing program for the testing and evaluation of both Acid-Thorex and Purex flowsheets in HTGR fuel reprocessing. The tests were conducted to extend earlier studies on the effects of solvent degradation, feed solids impact, and decontamination performance using tracer $\mathrm{Zr}-95$. Experiments to date indicate that acceptable operation is attainable in the reprocessing of HTGR fuels through the use of tributyl phosphate (TBP) extractant and pulsed solvent extraction columns. A centrifugal contactor is acceptable for the extraction step of the Purex flowsheet. 
$*$
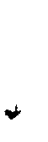

. 
CONTENTS

ABSTRACT . . . . . . . . . . . . . . . . . . . . . . . iii

1. INTRODUCTION . . . . . . . . . . . . . . . . . . . . . 1

2. SUMMARY . . . . . . . . . . . . . . . . . . . . 3

3. REQUTREMENTS . . . . . . . . . . . . . . . . . . . . . 4

4. DESCRIPTION OF EQUIPMENT AND CHEMICALS USED . . . . . . . . . . 6

5. FLOWSHEET DEVELOPMENT . . . . . . . . . . . . . . . 15

5.1. Acid-Thorex Flowsheet . . . . . . . . . . 15

5.2. Purex Flowsheet . . . . . . . . . . . . . 18

5.3. Plutonium Partition Flowsheet . . . . . . . . . 20

6. EXPERIMENTAL. . . . . . . . . . . . . . . . . . . 23

7. DISCUSSION AND RECOMMENDATIONS . . . . . . . . . . . . 25

7.1. Column Recommendations - HRRF Flowsheet ....... . 25

7.2. Column Efficiency ............... 25

7.2.1. $2 \mathrm{~A}$ and $3 \mathrm{~A}$ Extraction-Scrub Efficiency - Acid-

Thorex Process . . . . . . . . . . 29

7.2.2. $2 B$ and $3 B$ Column Stripping Efficiency - Acid Thorex Process . . . . . . . . . . . . 29

7.2.3. 5A and 6A Extraction-Scrub Efficiency - Purex Process . . . . . . . . . . . . 29

7.2.4. $5 \mathrm{~B}$ and $6 \mathrm{~B}$ Column Stripping Efficiency - Purex Process . . . . . . . . . . . . . . 29

7.3. Continuous Phase Recommendations - HRRF Flowsheet . . 30 7.3.1. Acid-Thorex Process . . . . . . . . . 30

7.3.2. Modified Purex Process .......... 30

7.3.3. Plutonium Partitioning . . . . . . . 30

7.4. Cartridge Recommendations . . . . . . . . . . 32

7.5. Flowsheet Recommendations - HRRF . . . . . . . . 32

7.6. Zirconium Decontamination . . . . . . . . . . 33

7.7. Simulated Solvent Degradation - Effects of Dibutyl
Phosphate . . . . . . . . . . . . 34

7.8. Centrifugal Contactor Studies . . . . . . . . . 37 
7.9. Effect of Feed Solids ................ 46

7.10. Analysis of Stream Samples . . . . . . . . . . 47

7.11. Other Fuel Cycle Applicability . . . . . . . . . . 47

7.12. Future Work . . . . . . . . . . . . . . 48

ACKNOWLEDGMENTS . . . . . . . . . . . . . . . . . . 49

APPENDIX: PILOT PLANT OPERATIONAL DATA . . . . . . . . . . 50

REFERENCES . . . . . . . . . . . . . . . . . . . 78

\section{FIGURES}

1. Overall view of the solvent extraction pilot plant . . . . 7

2. Second (control) level of the solvent extraction pilot

plant........................ 8

3. Second and third levels of the solvent extraction pilot

plant showing pulsed column details............ 9

4. Interface control instrumentation . . . . . . . . . . . 10

5. Column pulse generating mechanism . . . . . . . . . . 11

6. Centrifugal contactor unit. . . . . . . . . . . . . 13

7. Gas chromatogram of $30 \% \mathrm{TBP} / \mathrm{NPH}$ solvent . . . . . . . . 14

8. HEU-HRRF Acid-Thorex flowsheet: first uranium-thorium cycle, second and third uranium cycles . . . . . . . 16

9. HEU-HRRF Purex flowsheet: two uranium cycles........ 19

10. HEU-HRRF Acid-Thorex flowsheet: first uranium-thorium cycle, plutonium partition ............... . 21

11. Measured $\mathrm{Zr}-95$ decontamination factors . . . . . . . . 36

12. Centrifugal contactor $1 \mathrm{~A}$ and column $1 \mathrm{~S}$ with airlift

transfer .................. . . 39

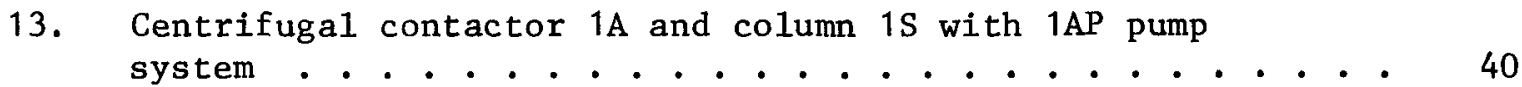

14. Centrifugal contactor efficiency study flowsheet: thorium 30\% TBP system .................... 42

15. Centrifugal contactor efficiency study flowsheet: uranium - 30\% TBP system . . . . . . . . . . . 
TABLES

1. Recommended column internals description of HEU-HRRF

Acid-Thorex process . . . . . . . . . . . . . . 26

2. Recommended column internals description of HEU-HRRF modified Purex process . . . . . . . . . . . . . . . . . 27

3. Pilot plant column internals description of plutonium partition . . . . . . . . . . . . . . . . . . . . .

4. HRRF Acid-Thorex flowsheet - second and third uranium cycles recommended continuous phase for the solvent extraction columns . . . . . . . . . . . . . . . . . . .

5. HEU-HRRF Purex flowsheet - two cycles recommended continuous phase for the solvent extraction columns . . . . . . . . .

6. HRRF Acid-Thorex flowsheet - plutonium partition continuous phase used for the solvent extraction columns . . . . . . . 31

7. Centrifugal contactor and column cartridge description. . . . 44

A-1. Tentative uranium product specification . . . . . . . . . 51

A-2. Tentative thorium product specification for storage . . . . 52

A-3. HRRF Acid-Thorex process: Operating data for column 1A (Extraction) in $1 \mathrm{~A}-1 \mathrm{~S}$ two-column system . . . . . . . 53

A-4. HRRF Acid-Thorex process: Operating data for column 1S (scrub) in $1 \mathrm{~A}-1 \mathrm{~S}$ two-column system ........... . 54

A-5. HRRF Acid-Thorex process: Operating data for column 1A-1S single-column system ................. 55

A-6. HRRF Acid-Thorex process: Operating data for column 1BX. . . 56

A-7. HRRF Acid-Thorex process: Operating data for column 1BS. . 57

A-8. HRRF Acid-Thorex process: Operating data for column 1C . . 58

A-9. HRRF Acid-Thorex process: Operating data for centrifugal contactor 1A. .................... 59

A-10. HRRF Acid-Thorex process: Operating data for column 1S in centrifugal contactor (1A) - 1S system . . . . . . . . 60

A-11. HRRF Acid-Thorex process: Operating data for column 2A . . . 61

$A-12$. HRRF Acid Thorex process: Operating data for column 2B . . . 62

A-13. HRRF Acid-Thorex process: Operating data for column 3A . . 63

A-14. HRRF Acid-Thorex process: Operating data for column 3B . . . 64

A-15. HRRF modified Purex process: Operating data for column 5A. . 65

A-16. HRRF modified Purex process: Operating data for column 5B. . 66 
A-17. HRRF modified Purex process: Operating data for column 6A. . 67

A-18. HRRF modified Purex process: Operating data for column 6B. . 68

A-19. HRRF Acid-Thorex process: Operating data for column 1PUX . . 69

A-20. HRRF Acid-Thorex process: Operating data for column 1 PUS. . 70

A-21. HRRF modified Purex process: Operating data for centrifugal contactor 5A. . . . . . . . . . . . . . . . 71

A-22. Centrifugal contactor efficiency study: Steam and sample data for thorium-30\% TBP system . . . . . . . . . . . 72

A-23. Centrifugal contactor efficiency study: Stream and sample data for uranium-30\% TBP system . . . . . . . . . . . 73

A-24. Centrifugal contactor efficiency study: Calculated thorium loss and flow rate data for $30 \% \mathrm{TBP} / \mathrm{NPH}$ system . . . . . 74

A-25. Centrifugal contactor efficiency study: Calculated uranium loss and flow rate data for $30 \% \mathrm{TBP} / \mathrm{NPH}$ system . . . . . 75

A-26. Centrifugal contactor efficiency study: Data comparison for thorium-30\% TBP system . . . . . . . . . . . . 76

A-27 Centrifugal contactor efficiency study: Data comparison for uranium-30\% TBP system . . . . . . . . . . . . . 77 


\section{INTRODUCTION}

This interim report contains results from the solvent extraction deve1opment work at General Atomic Company (GA) funded by the Department of Energy (DOE) HTGR Fuel Recycle Development Program. The work was performed in pilot plant equipment from January 1976 to October 1977. Prior work is described in an earlier interim report (Ref. 1). This solvent extraction development work at GA was directed toward the testing and verification of Acid-Thorex (Ref. 2) and modified Purex (Ref. 3) flowsheets for high-enrichment uranium (HEU) high-temperature gas-cooled reactor (HTGR) fuel reprocessing.

The HTGR fuel is comprised of discrete fertile and fissile particles. The fertile particles are BISO coated thorium oxide kernels and the fissile particles are TRISO coated uranium oxy-carbide material (Ref. 4). In HTGR fuel reprocessing, the fertile and fissile components are separated by pneumatic classification, and the fissile core material is converted to the oxide form during head-end operations. Dissolution of the oxide form of the fuel is accomplished in subsequent process operations in nitric acid (fissile) or Thorex (13 M nitric acid-0.1 M aluminum nitrate-0.05 M hydrofluoric acid) (fertile). A feed adjustment is performed as required on resultant dissolver product to bring the acidity and heavy metal concentration within prescribed values.

Solvent extraction is used to separate and recover bred U-233 and unburned U-235 from the fertile and fissile streams, respectively. The recovery of these fissionable isotopes is accomplished through the use of an organic extractant, i.e., 30 vol \% tributyl phosphate (TBP) in normal paraffin hydrocarbon (NPH) diluent. The Acid-Thorex flowsheet is used in the solvent extraction of the fertile fuel fraction, and a modified Purex flowsheet is used in the solvent extraction of the fissile fuel fraction 
The scope of the work reported herein includes:

1. A study of the applications of the Acid-Thorex process (Ref. 2) and a modified Purex process (Ref. 3) for the reprocessing of HEU-HTGR fuels.

2. The definition and evaluation of solvent extraction flowsheets for the reprocessing of HEU fuels in the HTGR recycle reference facility (HRRF).

3. Optimization of pulse column designs.

4. Performance evaluation of a Robate ${ }^{\circledR}$ centrifugal contactor for HRRF applicability.

Previous development work at GA (Ref. 1) has dealt with the fertile kernel reprocessing. The present study extends this work, with emphasis on applicability to HEU-HRRF. In addition, recent findings on the second and third Acid-Thorex cycles and two cycles of the modifled Purex process are contained in this report. 


\section{SUMMARY}

The solvent extraction pilot plant at GA was used to test flowsheets developed for ultimate use in HRRF. The solvent extraction operations in this study were performed in pulsed columns of 5.1 to $7.6 \mathrm{~cm}$ (2 to 3 in.) in diameter. Thirty percent TBP/NPH was used as the solvent in these studies, and recovery of greater than $99 \%$ of the thorium and/or uranium present in feed solutions was demonstrated.

Tests conducted to evaluate the impact of dibutyl phosphate (DBP) on zirconium decontamination in the Acid-Thorex process indicate that a higher level of solvent degradation is allowable prior to the occurrence of deleterious results of a magnitude measured earlier in the Purex process (Ref. 5).

The performance of a centrifugal contactor as the primary extraction unit was evaluated in the present work. Methods for coupling the centrifugal contactor with the pilot plant pulsed column system were developed. The unit is not recommended for the initial solvent/aqueous cycle in the Acid-Thorex flowsheet; however, performance of the unit in the modified Purex flowsheet tests was satisfactory.

The effect of solids in selected feed solutions was assessed. The impact of feed solids on uranium and thorium losses in the Acid-Thorex process was found to be small. Reduced zirconium decontamination (factors of 2 to 5) were measured as a result of feed solids content.

Acceptable performance has been demonstrated in pilot plant studies of flowsheets developed for HRRF. The work performed to date indicates that the Acid-Thorex and modified Purex processes are adaptable to HTGR fuel reprocessing. 


\section{REQUIREMENTS}

Solvent extraction will be used in HRRF to separate and recover uranium and thorium from spent HTGR fuels. The specified solvent extraction flowsheets developed for use in HRRF were designed to provide a high degree of separation of uranium and thorium from other actinides, accompanying fission products, and chemical impurities. In general, multiple solvent extraction cycles are required to yield products of sufficient purity for use in fuel refabrication with the Acid-Thorex and modified Purex processes. The tentative product specifications for uranium and thorium used in this development work are given in Appendix A in Tables A-1 and A-2, respectively.

The guidelines followed in earlier work at GA (Ref. 1) for use in the solvent extraction development studies were also used in the present work. They include:

1. A practical height limitation of $12.2 \mathrm{~m}$ (40 ft) for column cartridges is set.

2. Solvent extraction system operation is to be conducted under conditions which permit ready recovery from upset conditions.

3. The maximum thorium loss via the extraction column raffinate stream is to be less than $0.1 \%$ in the Acid-Thorex process.

4. The maximum uranium loss per solvent extraction cycle is to be less than $0.1 \%$ in the Acid-Thorex and Purex processes.

5. For uranium and thorium separation in the Acid-Thorex process: 
a. The partition cycle uranium product stream is to contain less than 500 parts of thorium per million parts of uranium.

b. The partition cycle thorium product stream is to contain less than 20 parts of uranium per million parts of thorium.

6. In the Acid-Thorex process, the zirconium decontamination factor (DF) for the first cycle is to exceed 5 to prevent zirconium precipitation in the feed stream to the second thorium cycle, which is to be made acid deficient $\left(-\left[\mathrm{H}^{+}\right]\right)$.

7. The overall Acid-Thorex fission product DF required for the solvent extraction system as a whole is to be greater than $2 \times 10^{6}$ for uranium and greater than $10^{3}$ for thorium.

8. Due to radiological considerations, the Acid-Thorex and modified Purex process flowsheets and equipment developed must be applicable to remote operation and maintenance. 


\section{DESCRIPTION OF EQUIPMENT AND CHEMICALS USED}

The major equipment comprising the solvent extraction pilot plant at GA has been previously described in detail (Refs. 1 and 6). The columns and ancillary equipment are shown in Figs. 1 through 5.

The solvent extraction studies are generally conducted in glass col-

umns of 5.1 to $7.6 \mathrm{~cm}$ (2 to 3 in.) diameter, ranging in overall heights to $9 \mathrm{~m}(28 \mathrm{ft})$. The columns are fabricated from sections of commercially available glass pipe with glass crosses at the ends as disengaging sections. The column internals, which together with the glass columns constitute the pulse column cartridges, are made from commercially available stainless steel (316) nozzle and sieve plates and spacers.

Variable pulse generators, consisting of Teflon* bellows driven by adjustable-speed motors and throw cranks, supply the prescribed pulsing conditions to the contents of a solvent extraction column during operation. Pipe [2.5 cm (1 in.)] and flexible hose connect the solution-filled bellows to the column bottoms (see Fig. 5).

Provisions are included in the pilot plant for:

1. Process, feed, and product solution transfer and storage in stainless stee1 (304L) equipment.

2. Intercolumn airlifts and stream flow rate control.

3. Product concentration.

*duPont trademark. 


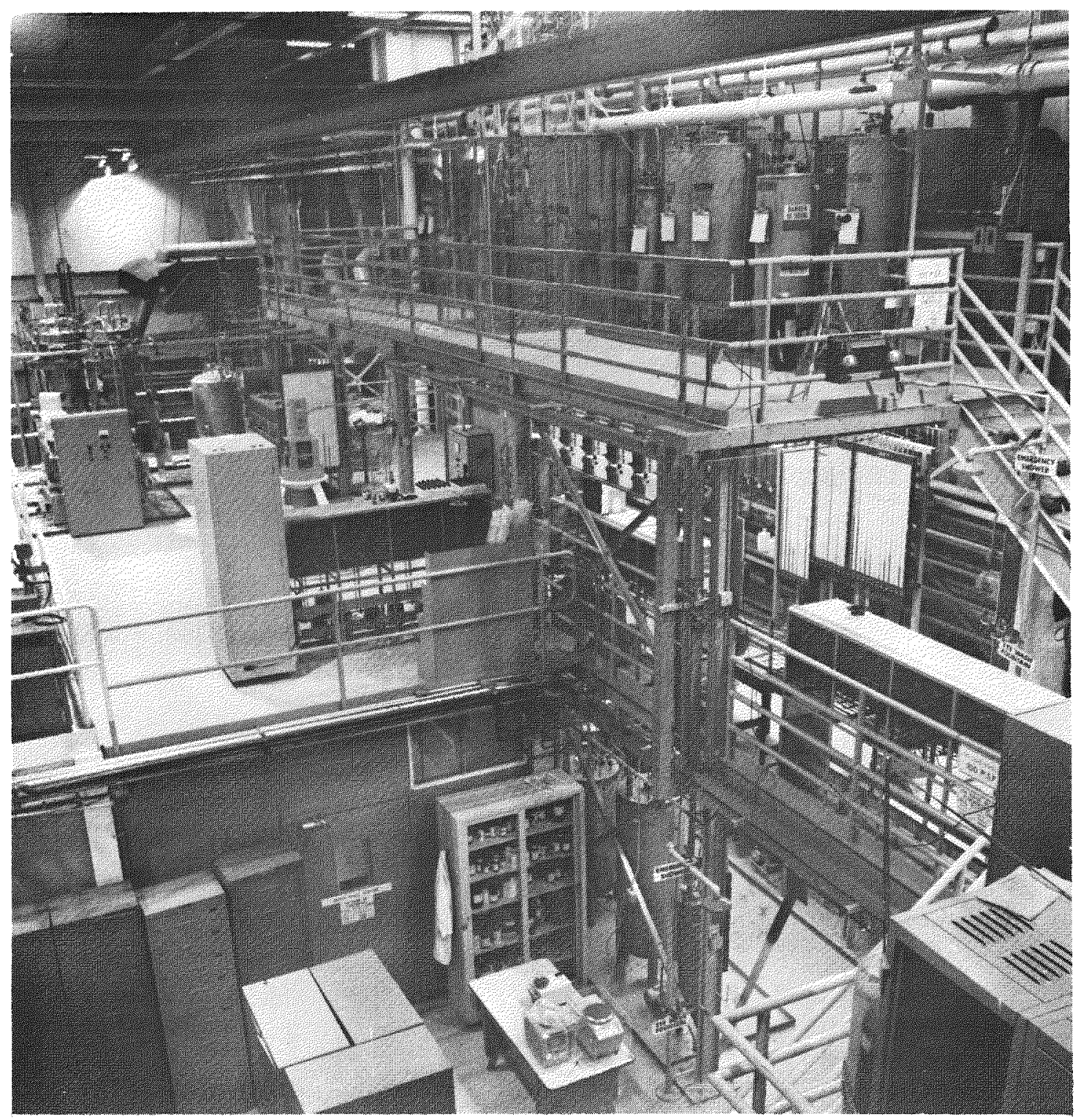

$781224 \mathrm{C}$

Fig. 1. Overall view of the solvent extraction pilot plant 


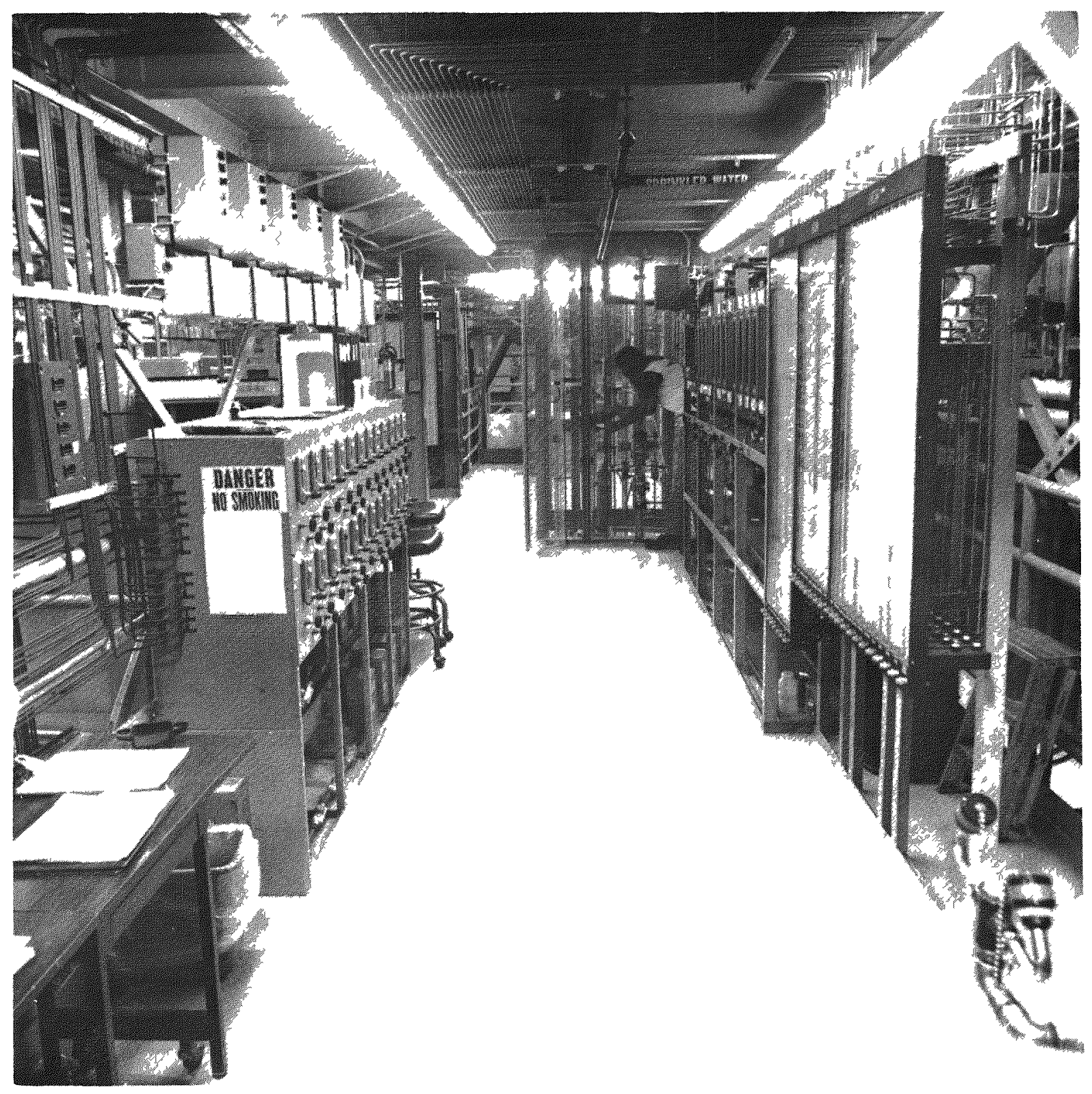

$781276 \mathrm{C}$

Fig. 2. Second (control) level of the solvent extraction pilot plant 


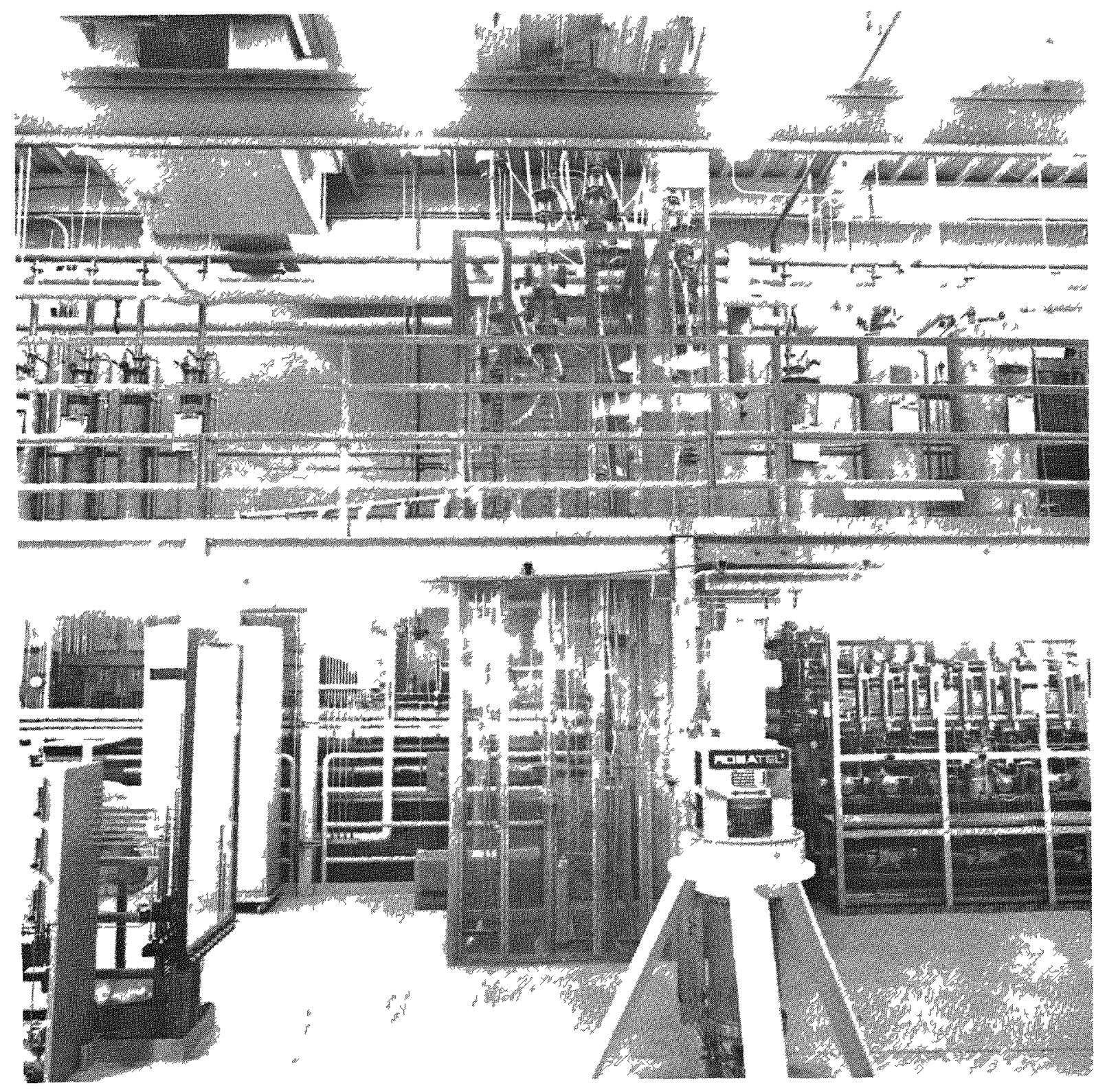

$781284 \mathrm{C}$

Fig. 3. Second and third levels of the solvent extraction pilot plant showing pulsed column details 


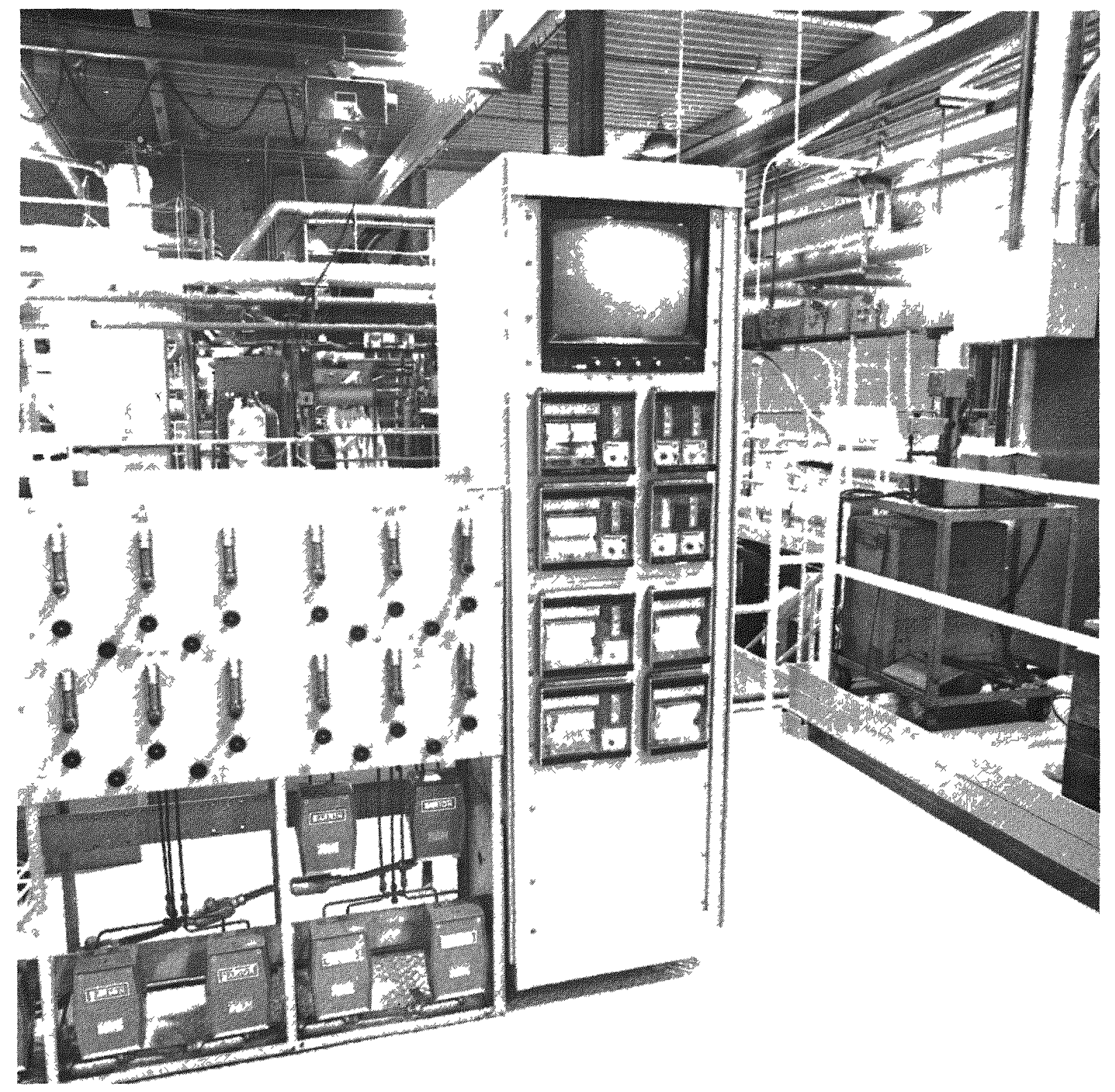

$781289 \mathrm{C}$

Fig. 4. Interface control instrumentation 


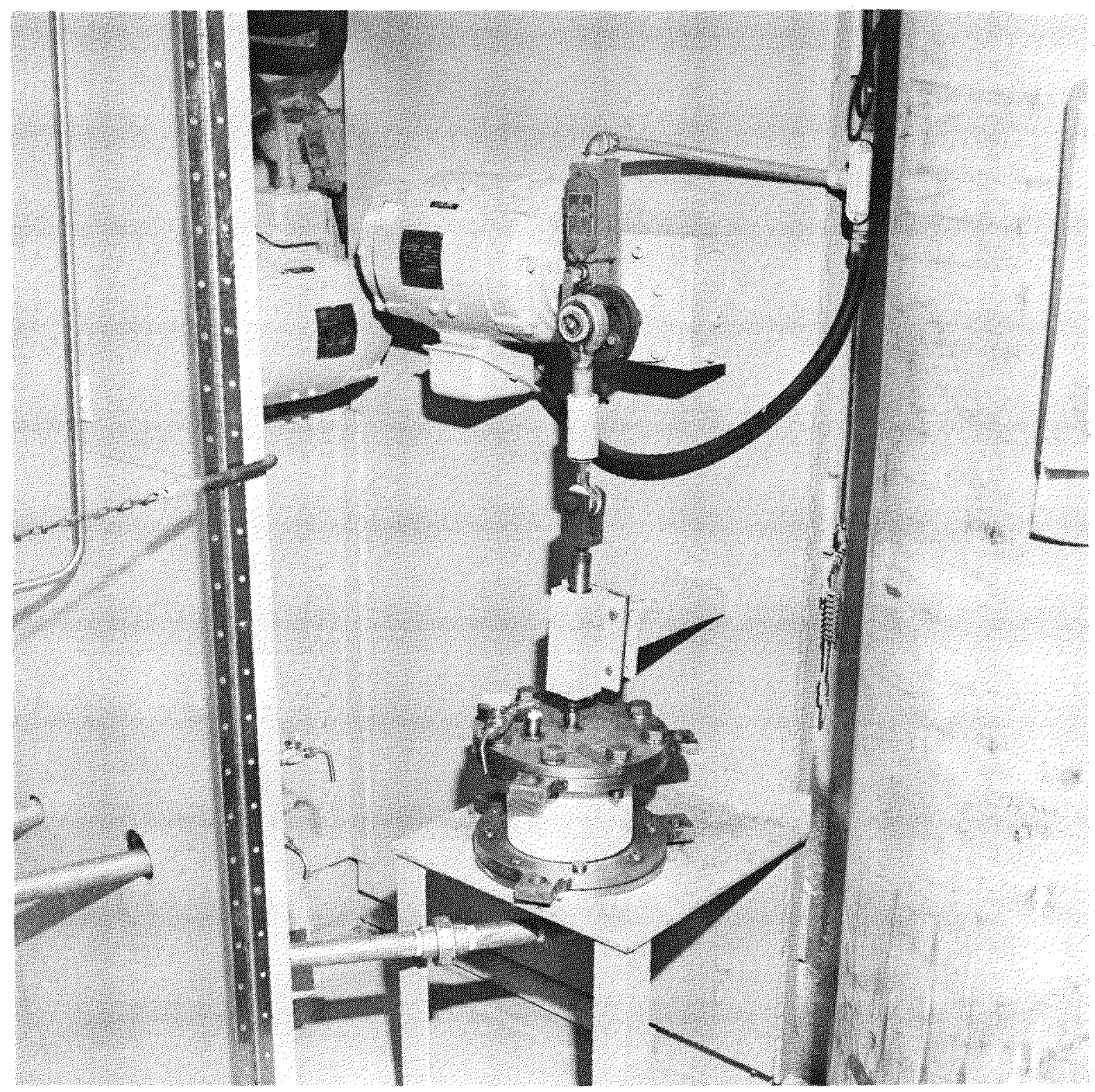

$781277 \mathrm{C}$

Fig. 5. Column pulse generating mechanism 
In addition to the above equipment, a centrifugal contactor* has been installed in the pilot plant facility (Fig. 6). The unit contains eight vertical centrifugal stages with a corresponding total solution volume of 3.36 liters for the stages. Power is supplied to the variable-speed dc motor through an electronic variator with 115-volt or 208-volt, 60-cycle input. The normal speed range of the unit is 1500 to $3000 \mathrm{rpm}$. Volume capacity of the unit is 60 to 180 liters per hour for a $1: 1$ flow ratio of aqueous to solvent phase.

The centrifugal contactor was installed and tested in the present work to permit an assessment of its potential use as the primary unit for the initial aqueous-solvent contact.

The active ingredient (extractant) of the solvent used in the pilot plant is technical grade tri-n-butyl phosphate (TBP). Normal paraffin hydrocarbon (NPH) is used to dilute the TBP concentration in the organic phase to $30 \%$ by volume. The NPH is a straight chained hydrocarbon** purchased to Atlantic Richfield Hanford Company specifications.

Figure 7 is a typical gas chromatogram obtained for the TBP/NPH solvent. The density of the purchased NPH is approximately $0.75 \mathrm{~g} / \mathrm{milliliter}$; the vendor is Southampton 0il Company, Sisbee, Texas. Concurrent work at GA has shown NPH to be more stable to nitration than diluents previously used in the Purex process (Ref. 7).

Reagent-grade uranyl nitrate hexahydrate (UNH) and thorium nitrate tetrahydrate (TNT) were used as required to prepare feed solutions of known concentration. These materials were purchased from Research Inorganic Chemicals Company, Sun Valley, California, and Tennessee Nuclear Corporation, Jonesboro, Tennessee, respectively. Technical-grade nitric acid ( $(14$ M) was used to adjust solution acidities as required.

*Robatel SLPI, Mode1 LX208 NC.

$* * \mathrm{NPH}$ consists primarily of $\mathrm{C}_{12} \mathrm{H}_{26}$ to $\mathrm{C}_{14} \mathrm{H}_{30}$ normal saturated hydrocarbons with an aromatic content of $<0.2 \%$. 


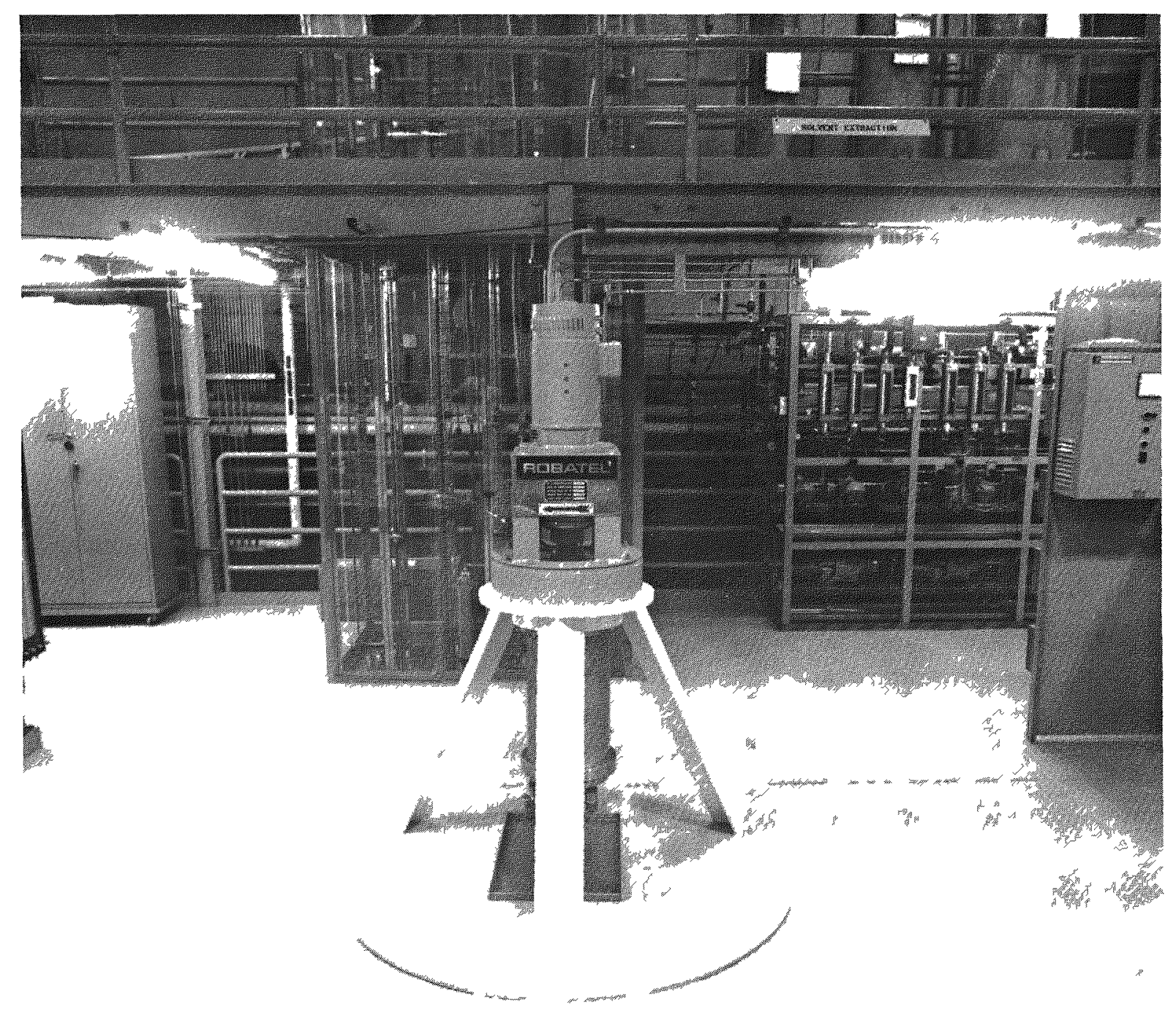

$781283 \mathrm{C}$

Fig. 6. Centrifugal contactor unit 


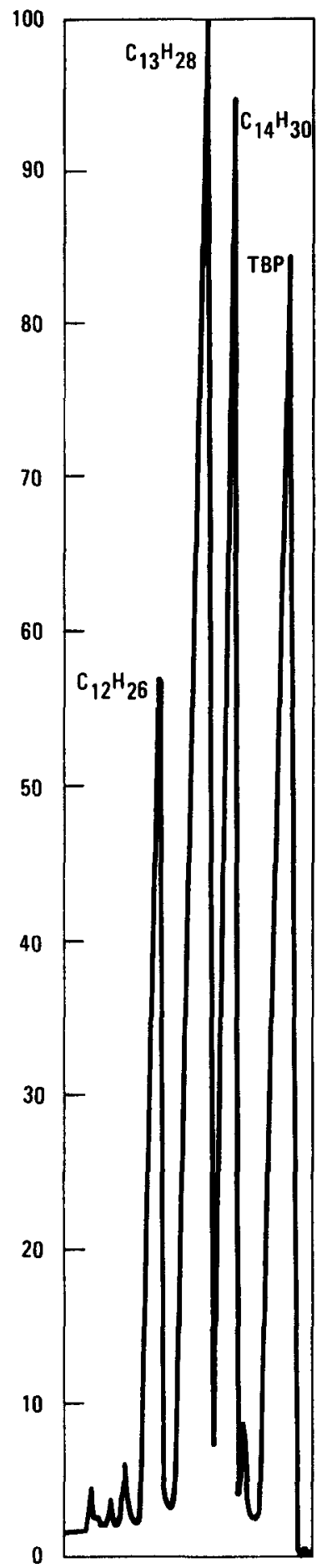

Fig. 7. Gas chromatogram of $30 \% \mathrm{TBP} / \mathrm{NPH}$ solvent. Conditions: 5-microliter sample, column $0 \mathrm{~V} 101,30.5 \mathrm{~cm} \times 0.32 \mathrm{~cm}, 150^{\circ} \mathrm{C}-1 \mathrm{~min}, 40^{\circ} \mathrm{C}$ rise/ min to $225^{\circ} \mathrm{C}$ final temperature, helium carrier gas 


\section{FLOWSHEET DEVELOPMENT}

The flowsheets developed in the present study are based on previous work (Refs. 2 and 3 ). Some changes from earlier flowsheets were necessitated by the characteristics of HTGR fuel. Dissolver solutions for solvent extraction processing prepared from HTGR fuels generally contain high levels of fission products and solid materials, e.g., finely divided silicon carbide and unburned graphite.

Earlier flowsheet development work at GA was directed toward design of solvent extraction systems for the Idaho National Engineering Laboratory (INEL) pilot plant (Ref. 8) and the HTGR Recycle Demonstration Facility (HRDF) (Ref. 9). Changes in the workscope of the HTGR Fuel Recycle Development Program at GA required development of the flowsheets contained herein for ultimate use in HRRF.

\subsection{ACID-THOREX FLOWSHEET}

Figure 8 contains the nominal Acid-Thorex process flowsheet tested and proposed for use in HEU-HRRF. The Acid-Thorex flowsheet developed provides a method for the recovery of uranium (U-233) and thorium from the HTGR fertile process stream. Stream and relative flow rate data for the first uranium-thorium cycle and the second and third uranium cycles are presented in Fig. 8. No work was conducted in this interim study on the second thorium cycle.

In the proposed partition flowsheet (Fig. 8), uranium and thorium in the $1 \mathrm{AF}$ feed stream (Stream 1) are extracted into $30 \% \mathrm{TBP} / \mathrm{NPH}$. Fission products and chemical impurities remain in the aqueous phase and are removed via the $1 \mathrm{AW}$ aqueous waste stream (Stream 7). The top section of the $1 \mathrm{~A}$ column (above the $1 \mathrm{AF}$ feed point) is the scrub section; i.e., the $1 \mathrm{~A}$ column is operated in a compound extraction-scrub mode. The purpose 


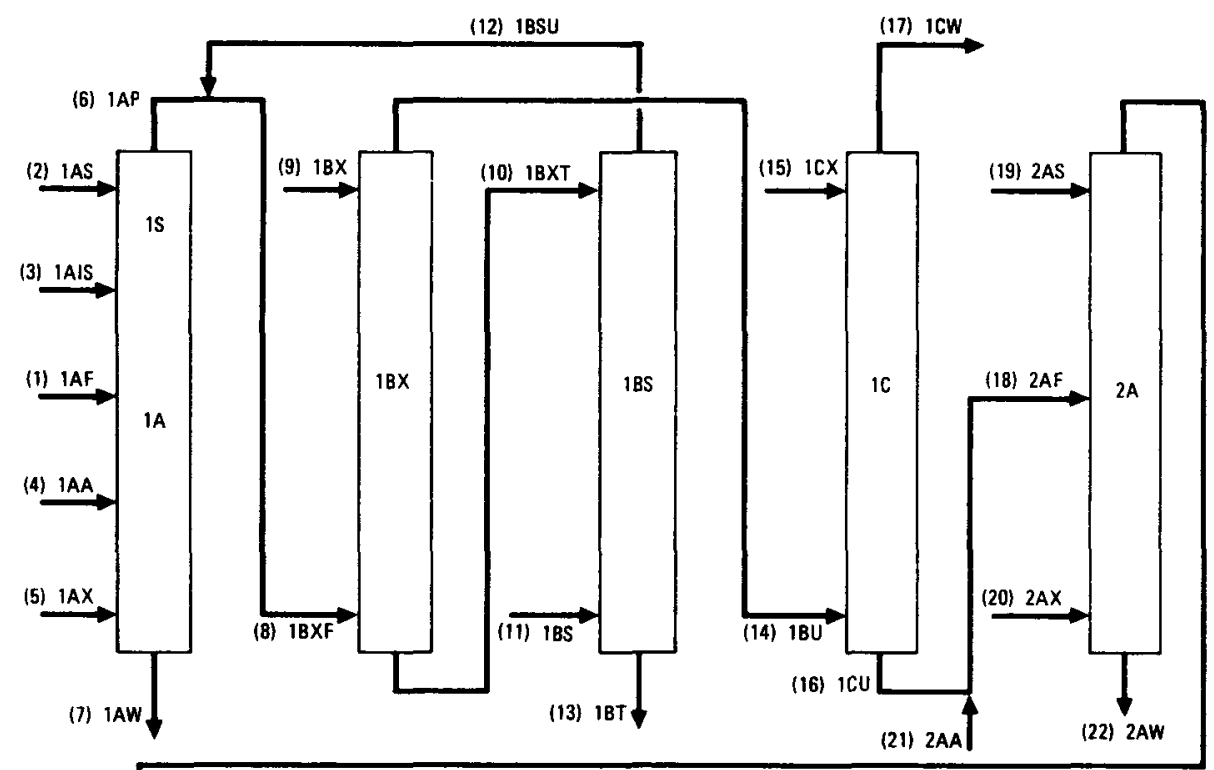

\begin{tabular}{|c|c|c|c|c|c|}
\hline \multirow[b]{2}{*}{ STREAM } & \multirow[b]{2}{*}{$\begin{array}{c}\text { STREAM } \\
\text { NO }\end{array}$} & \multirow[b]{2}{*}{$\begin{array}{l}\text { RELATIVE } \\
\text { FLOW } \\
\text { RATE } \\
\end{array}$} & \multicolumn{3}{|c|}{ COMPOSITION } \\
\hline & & & $\underset{(G / L)}{U}$ & $\begin{array}{c}\text { Th } \\
\text { (G/L) }\end{array}$ & $\begin{array}{c}\mathrm{HNO}_{3} \\
(\mathrm{M})^{3}\end{array}$ \\
\hline IAF & 1 & 100 & 35 & 348 & 10 \\
\hline IAS & 2 & 104 & & & 001 \\
\hline IAIS & 3 & 26 & & & 50 \\
\hline IAA & 4 & 32 & & & 130 \\
\hline IAX & 5 & 1000 & & {$[30 \%$ TBP] } & \\
\hline IAP & 6 & 1000 & 35 & 35 & \\
\hline IAW & 7 & 262 & & FISSION PRODUCTS & \\
\hline $18 \times F$ & 8 & 1180 & & & \\
\hline $18 x$ & $g$ & 600 & & $\left(\mathrm{Fe}^{+2}=001 \mathrm{M}\right)$ & 02 \\
\hline $18 \times T$ & 10 & 600 & & & \\
\hline IBS & 11 & 180 & & [30\% TBP] & \\
\hline IBSU & 12 & 180 & & & \\
\hline IBT & 13 & 600 & TRACE & 102 & \\
\hline IBU & 14 & 1180 & 298 & & \\
\hline $10 x$ & 15 & 593 & & & 001 \\
\hline icu & 16 & 593 & 593 & & \\
\hline $1 \mathrm{CW}$ & 17 & 1180 & & {$[30 \%$ TBP] } & \\
\hline $2 A F$ & 18 & 771 & 6 & & 30 \\
\hline 2AS & 19 & 85 & & $\left(\mathrm{Fe}^{+2}=0005 \underline{M}\right)$ & 03 \\
\hline $2 A X$ & 20 & 215 & & [30\% TBP] & \\
\hline $2 A A$ & 21 & 178 & & & 130 \\
\hline 2AW & 22 & 856 & & & \\
\hline $2 A U$ & 23 & 215 & & & \\
\hline $2 B X$ & 24 & 192 & & & 001 \\
\hline $28 \mathrm{BU}$ & 25 & 192 & & & \\
\hline $2 B W$ & 26 & 215 & & [30\% TBP] & \\
\hline 3AF & 27 & 250 & & & \\
\hline 3AS & 28 & 23 & & & 03 \\
\hline $3 A X$ & 29 & 100 & & [30\% TBP] & \\
\hline 3AA & 30 & 58 & & & 130 \\
\hline SAW & 31 & 273 & & & \\
\hline $3 A U$ & 32 & 100 & & & \\
\hline $3 B F$ & 33 & 100 & & & \\
\hline $3 B X$ & 34 & 108 & & & 001 \\
\hline $38 W$ & 35 & 100 & & [30\% TBP] & \\
\hline 3BU & 36 & 108 & & & \\
\hline 3WR & 37 & 3 & & [NPH] & \\
\hline $3 w s$ & 38 & 03 & & [NPH] & \\
\hline $3 w w$ & 39 & 03 & & [NPH] & \\
\hline 3wu & 40 & 108 & & & \\
\hline
\end{tabular}

Fig. 8. HEU-HRRF Acid-Thorex flowsheet: first uranium-thorium cycle, second and third uranium cycles 
of the scrub section is to remove fission products from the loaded organic phase and return them to the $1 \mathrm{AW}$ waste stream (Stream 7).

In the 1BX (partition) and 1BS (partition-scrub) columns, uranium and thorium are separated from each other. This separation is accomplished by adjusting phase flow ratios and nitric acid concentrations to favor uranium distribution in the organic phase with a resultant transfer of thorium to the aqueous phase. The thorium exits the 1BS column via the 1BT stream (Stream 13). The 1BT stream is used to prepare feed for the second thorium cycle following denitration and concentration. The uranium remains in the organic phase and overflows the $1 \mathrm{BX}$ column in the $1 \mathrm{BU}$ stream (Stream 14).

The uranium is stripped by a dilute nitric acid stream from the organic phase in the $1 \mathrm{C}$ column and exits the $1 \mathrm{C}$ column in the 1CU stream (Stream 16). The 1CW organic stream (Stream 17) overflows the 1C column and is treated in a solvent washing system (Ref. 1) which utilizes sodium carbonate solution to remove chemical impurities, fission products, and solvent degradation products prior to reuse.

The HEU-HRRF flowsheet differs from an earlier flowsheet developed for the proposed INEL pilot plant in that uranium product from the first Acid-Thorex cycle will be fed directly to the second and third uranium cycles without concentration. These second and third cycles are required to produce a uranium product of sufficient purity for use in fuel refabrication. The second and third cycles consist of two extraction-scrub and stripping operations. The incoming 2AF feed stream (Stream 18) is processed through these cycles for additional thorium separation and fission product decontamination.

Plutonium will not be partitioned in separate columns in the HRRF flowsheet of the first Acid-Thorex cycle due to operability problems with successive plutonium and thorium partition columns. The work conducted to test a flowsheet in which plutonium partitioning would be accomplished 
in separate columns in the first Acid-Thorex cycle* is discussed in Section 5.3 .

As present1y planned, plutonium will be chemically reduced with hydrazine-stabilized ferrous nitrate in the $1 \mathrm{BX}$ column and allowed to follow the thorium product stream (Stream 13). A separation of thorium and plutonium would be required in the second thorium cycle prior to reuse of the thorium source material.

A provision is incorporated in the second uranium cycle of the AcidThorex process for the separation of residual plutonium from uranium. The plutonium separation is accomplished through the addition of hydrazinestabilized ferrous nitrate in the $2 \mathrm{~A}$ extraction-scrub column. The ferrous nitrate chemically reduces the $\mathrm{Pu}^{+4}$ to $\mathrm{Pu}^{+3}$, which is inextractable in the organic phase. Plutonium reduced to valence +3 exits the $2 \mathrm{~A}$ column with the fission product waste stream (Stream 22). Final uranium product leaves the $3 B$ stripping column via the $3 B U$ stream (Stream 36) and is subjected to an $\mathrm{NPH}$ wash prior to concentration.

Hydroxylamine nitrate could possibly be substituted for ferrous nitrate as a plutonium reductant but some developmental verification work is needed.

\subsection{PUREX FLOWSHEET}

Figure 9 contains two cycles of the modified Purex process flowsheet tested and proposed for use in HEU-HRRF. The developed flowsheet will enable a recovery of uranium from the fissile stream during HTGR fuel reprocessing. Stream and relative flow rate data for two cycles of the process are presented in Fig. 9. A third cycle will be used in HRRF to achieve final uranium product specification (see Appendix, Table A-1).

*No plutonium was used in pilot plant studies; however, chemical additions necessary to reduce plutonium were made to simulate operation with plutonium present. 


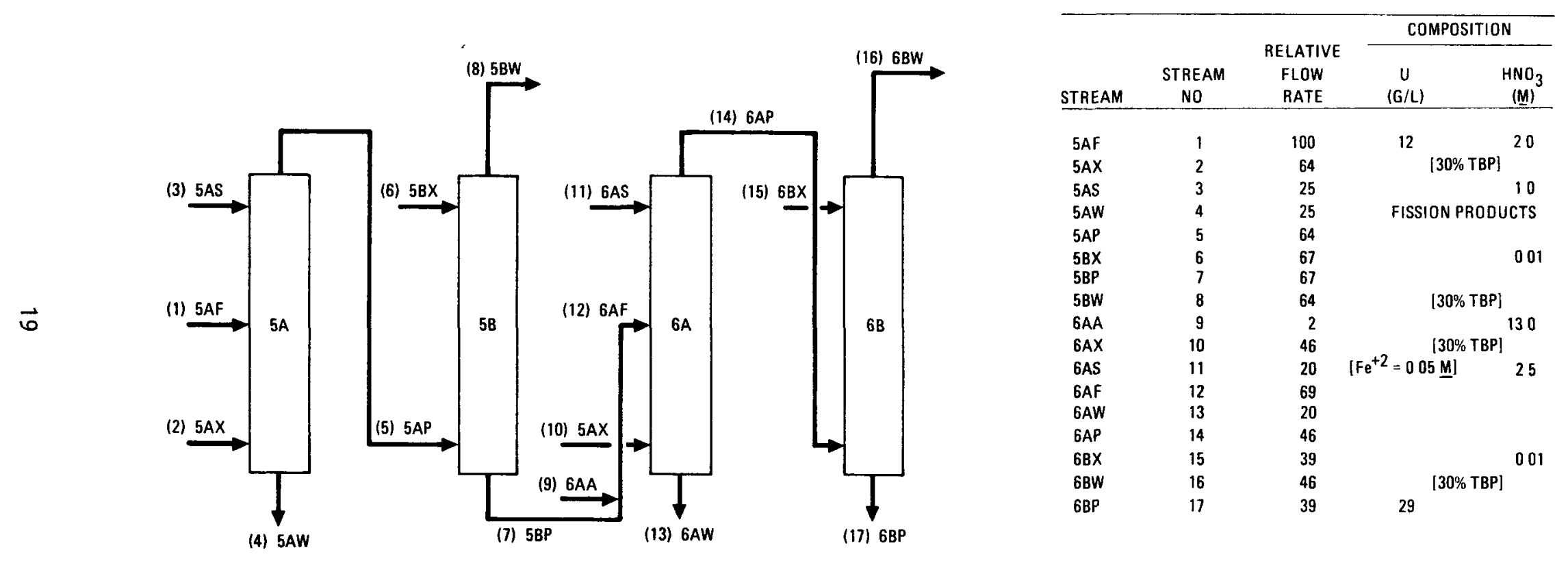

Fig. 9. HEU-HRRF Purex flowsheet: two uranium cycles 
Ultimate use of the recovered uranium in fuel manufacturing is contingent on the amount of $\mathrm{U}-236$ present in the U-235 product. Uranium-235 is a neutron poison and, therefore, its level limits the use of recovered uranium product. As presently planned, the recovered uranium from the fissile stream will be recycled once for use in fuel refabrication. The fissile fuel will then be retired without reprocessing. Future improvements in isotopic separation methods may allow reuse of the retired fuel at a later time.

The column configuration for two cycles of the modified Purex flowsheet is identical to that used in the second and third uranium cycles of the above-described Acid-Thorex flowsheet. In the proposed flowsheet, uranium-bearing (U-235) feed solution prepared from secondary fissile burner ash is fed to a compound extraction-scrub (5A) column. The uranium is extracted into the $30 \% \mathrm{TBP} / \mathrm{NPH}$ organic phase and overflows the $5 \mathrm{~A}$ column in the 5AP stream (Stream 5). The fission products and chemical impurities are removed from the $5 \mathrm{~A}$ column via the $5 \mathrm{AW}$ aqueous waste stream (Stream 4).

Uranium product from the $5 \mathrm{~A}$ column is introduced into the bottom of the $5 \mathrm{~B}$ column for stripping of uranium to the aqueous phase. The uraniumdepleted 5BW organic stream (Stream 8) overflows the 5B column and is treated in a sodium carbonate washing system (Ref. 1) prior to reuse. The uranium product leaves the 5B column via the 5BP stream (Stream 7) and, following acidity adjustment, becomes the 6AF feed solution for the second cycle (Stream 12). The second cycle is identical in process operation to the first cycle described above.

\subsection{PLUTONIUM PARTITION FLOWSHEET}

Figure 10 contains the plutonium partitioning flowsheet evaluated for potential use in the first cycle Acid-Thorex process for HRRF. Successful operation of the flowsheet would allow for a separation of the small amounts of plutonium isotopes during HTGR fuel reprocessing. This 


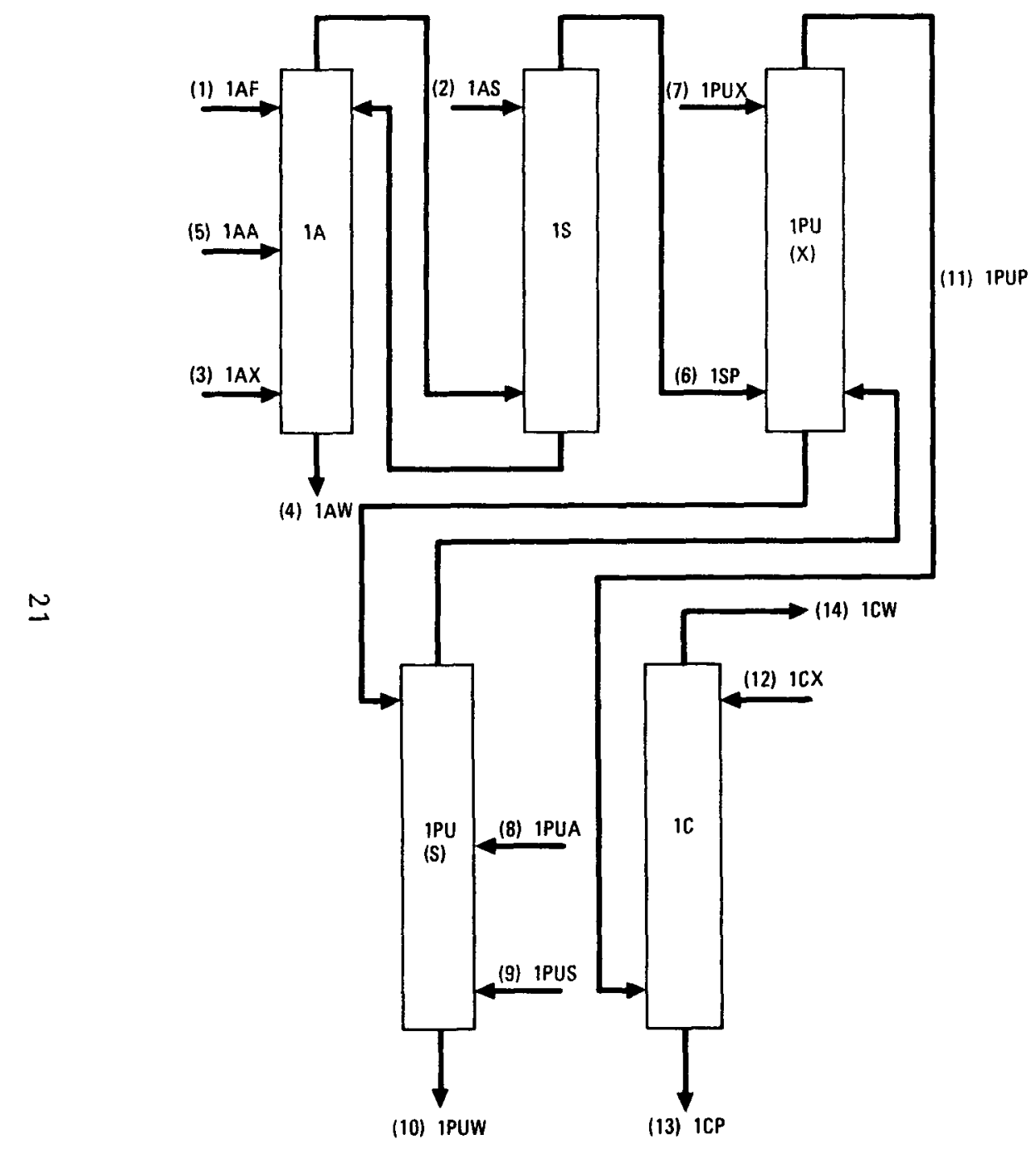

\begin{tabular}{|c|c|c|c|c|c|}
\hline \multirow[b]{2}{*}{ STREAM } & \multirow[b]{2}{*}{$\begin{array}{l}\text { STREAM } \\
\text { NO }\end{array}$} & \multirow[b]{2}{*}{$\begin{array}{l}\text { RELATIVE } \\
\text { FLOW } \\
\text { RATE }\end{array}$} & \multicolumn{3}{|c|}{ COMPOSITION } \\
\hline & & & $\begin{array}{c}U \\
(G / L)\end{array}$ & $\begin{array}{c}\text { Th } \\
(\mathrm{G} / \mathrm{L})\end{array}$ & $\begin{array}{c}\mathrm{HNO}_{3} \\
(\mathrm{M})^{-}\end{array}$ \\
\hline IAF & 1 & 100 & 14 & 348 & $<10$ \\
\hline 1AS & 2 & 190 & & & 10 \\
\hline IAX & 3 & 1200 & & {$[30 \% \mathrm{TBP}]$} & \\
\hline IAW & 4 & 320 & & & \\
\hline IAA & 5 & 30 & & & 130 \\
\hline ISP & 6 & 1200 & 12 & 29 & \\
\hline IPUX & 7 & 125 & & {$\left[\mathrm{Fe}^{+2}=005 \mathrm{M}\right]$} & 10 \\
\hline IPUA & 8 & 9 & & & 130 \\
\hline IPUS & $\mathrm{g}$ & 120 & & [30\% TBP] & \\
\hline IPUW & 10 & 135 & & & \\
\hline IPUP & 11 & 1320 & 11 & 26 & \\
\hline $10 x$ & 12 & 1200 & & & 001 \\
\hline ICP & 13 & 1200 & 12 & 29 & \\
\hline ICW & 14 & & [30\% TBP] & & \\
\hline
\end{tabular}

Fig. 10. HEU-HRRF Acid-Thorex flowsheet: first uranium-thorium cycle, plutonium partition 
plutonium (when using highly enriched uranium fissile particles) is mostly Pu-238. Stream and relative flow rate data for the flowsheet are given in Fig. 10. This flowsheet was operated in the cold pilot plant without plutonium but with all chemicals added to simulate plutonium partitioning.

In the plutonium partition operation, the incoming $1 \mathrm{SP}$ feed stream (Stream 6) is treated with nitric acid (Stream 7) containing hydrazinestabilized ferrous nitrate. Valence +3 plutonium exits the bottom of the $1 \mathrm{PU}(\mathrm{X})$ column with the aqueous phase, which is subsequently scrubbed in the $1 \mathrm{PU}(\mathrm{S})$ column. The separated plutonium exits the bottom of the $1 \mathrm{PU}(\mathrm{S})$ column in the 1PUW stream (Stream 10). Uranium and thorium in the partition flowsheet overflow the $1 \mathrm{PU}(\mathrm{X})$ and $1 \mathrm{PU}(\mathrm{S})$ column, and these overflow streams are combined to constitute the 1PUP stream (Stream 11).

Pilot plant operation of the plutonium partition flowsheet was found to be troublesome due to marginal stability. The interfaces for the $1 \mathrm{PU}(\mathrm{X})$ and $1 \mathrm{PU}(\mathrm{S})$ columns were difficult to control because of the low aqueous flow rates required to minimize thorium stripping into the aqueous stream (Stream 10). High thorium losses ( $>20 \mathrm{~g} /$ liter in some runs) to the plutonium partition stream (Stream 10) were common. In addition, recovery from flood conditions was time consuming.

As noted above, the use of two additional columns [1PU(S) and 1PU(X)] for plutnoium partitioning in the first Acid-Thorex cycle is not currently being considered for HRRF. 


\section{EXPERIMENTAL}

Data collected during pilot plant runs were used herein to evaluate run performance. Typical run data include measurements of:

1. Feed and process stream flow rates.

2. Stream temperatures.

3. Pulse amplitudes and frequencies for each column.

In addition, visual observations were recorded during each run, e.g., uranium colorline position and the occurrence of column flooding. Samples of end streams and intermediate locations were taken and retained for analysis during each solvent extraction run following attainment of steadystate operation at the nominal flow rates. The resultant analytical data were used to construct a profile of solvent extraction performance for a given run.

Flooding studies were made in several of the runs reported herein. Flooding is initiated in a column by increasing the pulse frequency to a point where the aqueous and organic phases cannot pass countercurrently through the column at a preset pulse amplitude [generally $2.5 \mathrm{~cm}$ (1 in.)]. Stable column operation, i.e., absence of flooding, was usually attained during column operation at 70 to $80 \%$ of the observed flooding frequency for a given column. Cyclic (regiona1) flooding sometimes occurs under column operation greater than approximately $90 \%$ of flooding frequency.

The cartridge (plate spacing and type) for each column was selected based on capacity and efficiency data. The cartridges that were tested were derived from previous studies (Ref. 1).

Normal and tracer zirconium were added to selected feed solutions in the present work to simulate the presence of this limiting fission product. 
The total quantity of zirconium added was equivalent to the amount of zirconium expected in equilibrium-spent HTGR fuels. The tracer used was $\mathrm{Zr}-95$ and additions of $\sim 10 \mathrm{mCl}$ were made to the respective feed solutions. Use of $\mathrm{Zr}-95$ allowed calculation of zirconium distribution in stream samples from subsequent gamma spectrometric analysis. Decontamination factors (DFs) were calculated from zirconium distribution data. The $\mathrm{Zr}-95$ tracer was utilized in the present work because chemical measurement of zirconium in samples containing heavy metals is difficult and subject to error.

Dibutyl phosphate (DBP) was added in selected feeds to simulate solvent degradation. The dibuty 1 phosphate added was isolated from a purchased mixture of $\sim 1: 1$ DBP-monobutyl phosphate (MBP) by chemical treatment prior to use. The addition of DBP permitted a study of the effects of solvent degradation in HTGR fuel reprocessing.

The feeds used in two solvent extraction runs conducted in the present study were prepared from solutions generated in pilot plant dissolution experiments. These feeds were selected because they contained solids typically present in HTGR fuel process solutions, e.g., graphite and/or silicon carbide. Solids generally follow the aqueous stream in the extraction column. Earlier work has shown that a feed solids carbon content in excess of $0.5 \%$ causes a deleterious effect in solvent extraction performance (Ref. 1). 


\section{DISCUSSION AND RECOMMENDATIONS}

\subsection{COLUMN RECOMMENDATIONS - HRRF FLOWSHEET}

As noted in Section 3, a maximum column height limit of $12.2 \mathrm{~m}$ ( $40 \mathrm{ft}$ ) was assumed due to anticipated building height limitations. The column heights recommended herein are based on pilot plant experience. Columns recommended are capable of remote operation and maintenance. The column heights for the HRRF Acid-Thorex process are given in Table 1. Table 2 contains recommended heights for the three cycles of the HEU-HRRF modified Purex process.

No column heights are suggested for a separate plutonium-partitioning operation in the proposed HEU-HRRF flowsheet. However, the column heights used in the pilot plant evaluation of a separate plutonium partition flowsheet are given in Table 3 .

\subsection{COLUMN EFFICIENCY}

Pilot plant operation of equipment at selected volume throughput rates and pulse frequencies is required to generate data suitable for determining the relative column diameters, plate types, plate hole sizes, and plate spacings for a given flowsheet. Tables A-3 through A-21 in the Appendix contain the data from pilot plant operations (Refs. 10 through 17).

The efficiency of each column tested in the flowsheets developed for HRRF has been satisfactory. The efficiency findings for the columns in the first cycle of the HRRF Acid-Thorex flowsheet are similar to those reported in earlier work at GA (Ref. 1). A discussion of the efficiency of other columns in HRRF flowsheet studies follows. 
TABLE 1

RECOMMENDED COLUMN INTERNALS DESCRIPTION OF HEU-HRRF ACID-THOREX PROCESS (a)

\begin{tabular}{|c|c|c|c|c|c|c|c|c|c|c|c|}
\hline \multirow[b]{2}{*}{ Column } & \multirow{2}{*}{\multicolumn{2}{|c|}{$\begin{array}{l}\text { Height of } \\
\text { Cartridge } \\
{[\mathrm{m}(\mathrm{ft})]}\end{array}$}} & \multirow{2}{*}{\multicolumn{2}{|c|}{$\begin{array}{c}\text { Column } \\
\text { i.d. } \\
{[\mathrm{cm} \text { (in.)] }}\end{array}$}} & \multicolumn{6}{|c|}{ Nozzle Plates (Stainless Steel) } & \multirow[b]{2}{*}{$\begin{array}{c}\text { Operating } \\
\text { Temperature } \\
\left({ }^{\circ} \mathrm{C}\right)\end{array}$} \\
\hline & & & & & $\begin{array}{l}\text { Nozzle(b) } \\
\text { Direction }\end{array}$ & \multicolumn{2}{|c|}{$\begin{array}{l}\text { Hole Size } \\
{[\mathrm{mm} \text { (in.)] }}\end{array}$} & $\begin{array}{c}\text { Free Area } \\
(\%)\end{array}$ & \multicolumn{2}{|c|}{$\begin{array}{c}\text { Plate Spacing } \\
{[\mathrm{cm} \text { (in.)] }}\end{array}$} & \\
\hline $1 \mathrm{~A}$ & 4.6 & (15) & 20.6 & $(8.1)$ & Down & 3 & $(1 / 8)$ & 23 & 5.1 & (2) & $20-25$ \\
\hline $1 \mathrm{~S}$ & 6.4 & (21) & 20.6 & $(8.1)$ & Down & 3 & $(1 / 8)$ & 23 & 5.1 & (2) & $20-25$ \\
\hline $1 \mathrm{BX}$ & 9.8 & (32) & 31.0 & $(12.2)$ & Up & 5 & $(3 / 16)$ & 23 & \multicolumn{2}{|c|}{ Graded $(c)$} & $20-25$ \\
\hline $1 \mathrm{BS}$ & 8.5 & $(28)$ & $15 \cdot 5$ & $(6.1)$ & $\mathrm{Up}$ & 5 & $(3 / 16)$ & 23 & 5.1 & $(2)$ & $20-25$ \\
\hline $1 \mathrm{C}$ & 7.0 & (23) & 31.0 & $(12.2)$ & Up & 5 & $(3 / 16)$ & 23 & \multicolumn{2}{|c|}{ Graded (c) } & 50 \\
\hline $2 \mathrm{~A}$ & 4.6 & $(15)$ & 15.5 & $(6.1)$ & Down & 3 & $(1 / 8)$ & 23 & 5.1 & $(2)$ & $20-25$ \\
\hline $2 S$ & 6.4 & (21) & 15.5 & $(6.1)$ & Down & 3 & $(1 / 8)$ & 23 & 5.1 & $(2)$ & $20-25$ \\
\hline $2 B$ & 8.5 & $(28)$ & 15.5 & $(6.1)$ & $\mathrm{Up}_{\mathrm{p}}$ & 5 & $(3 / 16)$ & 23 & 5.1 & (2) & 50 \\
\hline $3 \mathrm{~A}$ & 4.6 & (15) & 7.6 & $(3.0)$ & Down & 3 & $(1 / 8)$ & 23 & 5.1 & $(2)$ & $20-25$ \\
\hline $3 S$ & 6.4 & $(21)$ & 7.6 & $(3.0)$ & Down & 3 & $(1 / 8)$ & 23 & 5.1 & (2) & $20-25$ \\
\hline $3 B$ & 8.5 & $(28)$ & 7.6 & $(3.0)$ & Up & 5 & $(3 / 16)$ & 23 & 5.1 & (2) & 50 \\
\hline
\end{tabular}

(a) For pulse amplitudes of $2.5 \mathrm{~cm}$ (1 in.) for each column.

(b) Nozzle depths are $0.89 \mathrm{~mm}$ to $1.27 \mathrm{~mm}$ ( 0.035 to $0.050 \mathrm{in.}$ ) below plane of plate.

(c) Variable plate spacing from $10.2 \mathrm{~cm}$ (4 in.) at bottom of column to $5.1 \mathrm{~cm}$ (2 in.) at the top. 
TABLE 2

RECOMMENDED COLUMN INTERNALS DESCRIPTION OF HEU-HRRF MODIFIED PUREX PROCESS (a)

\begin{tabular}{|c|c|c|c|c|c|c|c|}
\hline \multirow[b]{2}{*}{ Column } & \multirow{2}{*}{\multicolumn{2}{|c|}{$\begin{array}{l}\text { Height of } \\
\text { Cartridge } \\
{[\mathrm{m}(\mathrm{ft})]} \\
\end{array}$}} & \multicolumn{4}{|c|}{ Nozzle Plates (Stainless Steel) } & \multirow{2}{*}{$\begin{array}{l}\text { Operating } \\
\text { Temperature } \\
\left({ }^{\circ} \mathrm{C}\right)\end{array}$} \\
\hline & & & $\begin{array}{l}\text { Nozzle(b) } \\
\text { Direction }\end{array}$ & & $\begin{array}{l}\text { e Size } \\
\text { (in.)] }\end{array}$ & $\begin{array}{c}\text { Free Area } \\
(\%)\end{array}$ & \\
\hline $5 \mathrm{~A}$ & 4.6 & (15) & Down & 3 & $(1 / 8)$ & 23 & $20-25$ \\
\hline $5 S$ & 6.4 & (21) & Down & 3 & $(1 / 8)$ & 23 & $20-25$ \\
\hline $5 B$ & 8.5 & (28) & Up & 5 & $(3 / 16)$ & 23 & 50 \\
\hline $6 \mathrm{~A}$ & 4.6 & (15) & Down & 3 & $(1 / 8)$ & 23 & $20-25$ \\
\hline $6 S$ & 6.4 & (21) & Down & 3 & $(1 / 8)$ & 23 & $20-25$ \\
\hline $6 \mathrm{~B}$ & 8.5 & (28) & Up & 5 & $(3 / 16)$ & 23 & 50 \\
\hline $7 \mathrm{~A}$ & 4.6 & (15) & Down & 3 & $(1 / 8)$ & 23 & $20-25$ \\
\hline $7 \mathrm{~S}$ & 6.4 & (21) & Down & 3 & $(1 / 8)$ & 23 & $20-25$ \\
\hline $7 \mathrm{~B}$ & 8.5 & (28) & Up & 5 & $(3 / 16)$ & 23 & 50 \\
\hline
\end{tabular}

(a) For pulse amplitudes of $2.5 \mathrm{~cm}$ ( 1 in.) for each column.

(b) Nozzle depths are $0.89 \mathrm{~mm}$ and $1.27 \mathrm{~mm}(0.035$ to $0.050 \mathrm{in.})$ below plane of plate. 
TABLE 3

PILOT PLANT COLUMN INTERNALS DESCRIPTION OF

PLUTONIUM PARTITION (a)

\begin{tabular}{|c|c|c|c|c|c|}
\hline \multirow[b]{2}{*}{ Column (b) } & \multirow[b]{2}{*}{$\begin{array}{l}\text { Height of } \\
\text { Cartridge } \\
{[\mathrm{m}(\mathrm{ft})]}\end{array}$} & \multicolumn{4}{|c|}{ Nozzle Plates (Stainless Steel) } \\
\hline & & $\begin{array}{l}\text { Nozzle } \\
\text { Direction }\end{array}$ & $\begin{array}{l}\text { Hole Size } \\
\text { [mm (in.) }]\end{array}$ & $\begin{array}{l}\text { Free } \\
\text { Area } \\
(\%)\end{array}$ & $\begin{array}{c}\text { Plate } \\
\text { Spacing } \\
{[\mathrm{cm} \text { (in.) ] }}\end{array}$ \\
\hline $1 \mathrm{PU}(\mathrm{X})$ & $5.8 \quad(19)$ & Up & $(3 / 16)$ & 23 & Graded $^{(d)}$ \\
\hline $1 \mathrm{PU}(\mathrm{S})$ & $5.2 \quad(17)$ & Up & $(3 / 16)$ & 23 & $(5.1)$ \\
\hline
\end{tabular}

(a) For pulse amplitudes of $2.5 \mathrm{~cm}$ (1 in.) for each column.

(b) Column diameters: $1 \mathrm{PU}(\mathrm{X})=7.6 \mathrm{~cm}(3.0$ in.), $1 \mathrm{PU}(\mathrm{S})=$ $5.1 \mathrm{~cm}(2.0 \mathrm{in.})$; operating temperatures: $1 \mathrm{PU}(\mathrm{X})=$ ambient, $1 \mathrm{PU}(\mathrm{S})=45^{\circ} \mathrm{C}$.

(c) Nozzle depths are $0.89 \mathrm{~mm}$ to $1.27 \mathrm{~mm}(0.035$ to $0.050 \mathrm{in.})$ below plane of plate.

(d) Variable plate spacing from $10.2 \mathrm{~cm}$ (4 in.) at bottom of column to $5.1 \mathrm{~cm}(2 \mathrm{in.})$ at top. 


\subsubsection{A and 3A Extraction-Scrub Efficiency - Acid-Thorex Process}

The A column operations consist of extraction of uranium into $30 \%$ $\mathrm{TBP} / \mathrm{NPH}$ solvent from an aqueous feed stream. The bulk of fission product decontamination occurs in the A columns. In pilot plant operations, recovery of greater than $99.9 \%$ of uranium was demonstrated in the A columns. Zirconium decontamination factors ranged from 250 to 2800 for the $2 \mathrm{~A}$ column to $7 \times 10^{4}$ across the entire second and third uranium. cycles.* Attempts to improve uranium recovery generally resulted in an increase in fission product extraction and, consequently, a reduction in fission product decontamination. Use of longer scrub sections (extension of A column lengths above the feed point) increased the zirconium DFs without reducing uranium recovery below $99.9 \%$.

\subsection{2. $2 \mathrm{~B}$ and $3 \mathrm{~B}$ Column Stripping Efficiency - Acid-Thorex Process}

The recovery of greater than $99.9 \%$ of feed uranium was demonstrated in the $\mathrm{B}$ column stripping operations.

\subsubsection{A and 6A Extraction-Scrub Efficiency - Purex Process}

Uranium recoveries in A column of greater than $99.9 \%$ were demonstrated in the pilot plant operations. Zirconium DFs on a uranium basis ranged from 450 to 750 for the $5 \mathrm{~A}$ column and 10 to 25 for the $6 \mathrm{~A}$ column.

\subsubsection{B and 6B Column Stripping Efficiency - Purex Process}

B column uranium losses were generally less than $0.05 \%$ under steadystate operation. Uranium losses increased to $1.0 \%$ in the $5 \mathrm{~B}$ column in the presence of $0.3 \mathrm{~g} / 1$ iter $\mathrm{DBP}$ in the $5 \mathrm{BW}$ stream. Zirconium DFs calculated for the $5 \mathrm{~B}$ and $6 \mathrm{~B}$ stripping columns were 1.2 in each case.

*Measured thorium-to-uranium DFs across the entire second and third cycles ranged from 2 to 30. 


\subsection{CONTINUOUS PHASE RECOMMENDATIONS - HRRF FLOWSHEET}

Three factors are predominant in the selection of the continuous phase for each column in the HRRF flowsheet. These three factors are: (1) column efficiency in performing the desired separation, (2) column control or operability, and (3) column interface position; i.e., the column interface is to be kept away from the product end to allow interfacial materials to exit with the column waste.

\subsubsection{Acid-Thorex Process}

Recommendations for the continuous phase in each column of the first Acid-Thorex cycle for the processing of HTGR fuel were made in earlier work at GA (Ref. 1). These recommendations were followed in the present study. Column continuous-phase recommendations for the second and third uranium cycles of the HRRF Acid-Thorex process are given in Table 4. Operation of the second and third cycle A columns in an organic continuous mode permits a physical isolation of any interfacial crud (and attendant fission product activity) from the product ends of the columns. This result is achieved because interfacial crud tends to follow the effluent stream. The above-1isted advantages for organic continuous-phase operation of the A columns offset the potential operational disadvantage of a more difficult recovery from flooding.

\subsubsection{Modified Purex Process}

Column continuous-phase recommendations for two cycles of the HRRF Purex process are given in Table 5. Pilot plant experience with the suggested operational modes was satisfactory.

\subsubsection{Plutonium Partitioning}

No continuous-phase recommendations are made for potential separate plutonium partitioning in the HRRF. The continuous phases used in the pilot plant studies simulating plutonium partitioning are given in Table 6 . 
TABLE 4

HRRF ACID-THOREX FLOWSHEET - SECOND AND THIRD URANIUM CYCLES RECOMMENDED CONTINUOUS PHASE FOR THE SOLVENT EXTRACTION COLUMNS

$\underline{\text { Column }}$

$2 \mathrm{~A}$

2B

$3 \mathrm{~A}$

$3 B$
Continuous Phase

Organic

Aqueous

Organic

Aqueous

TABLE 5

HEU-HRRF PUREX FLOWSHEET - TWO CYCLES

RECOMMENDED CONTINUOUS PHASE FOR THE SOLVENT EXTRACTION COLUMNS

$\underline{\text { Column }}$

$5 \mathrm{~A}$

$5 \mathrm{~B}$

$6 \mathrm{~A}$

$6 \mathrm{~B}$
Continuous Phase

Organic

Aqueous

Organic

Aqueous

TABLE 6

HRRF ACID-THOREX FLOWSHEET - PLUTONIUM PARTITION

CONTINUOUS PHASE USED FOR THE SOLVENT EXTRACTION COLUMNS

$\underline{\text { Column }}$

$1 \mathrm{PU}(\mathrm{X})$

$1 \mathrm{PU}(\mathrm{S})$
Continuous Phase

Aqueous

Aqueous 


\subsection{CARTRIDGE RECOMMENDATIONS}

The cartridge recommendation for each column in the HRRF flowsheet is based on column efficiency and capacity. The cartridge descriptions are given in Tables 1, 2, and 3 (see Section 7.1). The nozzle plates used in all cases are stainless steel with $23 \%$ free area. The hole diameters for aqueous and organic continuous operations are generally $4.8 \mathrm{~mm}$ (3/16 in.) and $8.2 \mathrm{~mm}$ (1/8 in.), respectively. Recent studies conducted in the pilot plant indicate that a slight capacity advantage is realized in the $1 \mathrm{BX}$ column with $4.8 \mathrm{~mm}$ (3/16 in.) diameter holes. Therefore, $4.8 \mathrm{~mm}$ ( $3 / 16 \mathrm{in.)}$ diameter holes are recommended for the $1 \mathrm{BX}$ column based on throughput considerations.

As noted in earlier work at GA (Ref. 1), operation of the 1A-1S system (extraction-scrub) as a single compound column is preferred. This mode of operation eliminates control problems in the HRRF Acid-Thorex flowsheet, particularly in the presence of a thorium-rich (second organic) phase. The formation of a second organic phase occurs when thorium concentration in the solvent exceeds 30 to $35 \mathrm{~g} / 1$ iter. This second organic phase causes operational difficulties at the column interface in a split organic continuous scrub section when apparent density difference is used to sense the interface position.

\subsection{FLOWSHEET RECOMMENDATIONS - HRRF}

The recommended flowsheets for use in HRRF are shown in Figs. 8 and 9 (see Sections 5.1 and 5.2). As presently planned, plutonium will not be partitioned in separate columns from the 1AP stream in the first cycle of the Acid-Thorex process. Rather, it is recommended that plutonium be allowed to follow the thorium in the process and exit the first cycle with the $1 \mathrm{BT}$ thorium product. The plutonium would subsequently be partitioned more effectively during the second thorium cycle in the 2D column.

In addition, it is recommended that plutonium be allowed to follow the uranium through the first cycle of the modified Purex process. The 
plutonium would be partitioned in the second cycle in the $6 \mathrm{~A}$ column and made to follow the $6 \mathrm{AW}$ waste stream.

\subsection{ZIRCONIUM DECONTAMINATION}

Zirconium was added to selected feed solutions in the HEU-HRRF flowsheet tests to allow calculation of arithmetic DFs.* Zirconium was chosen for study to represent the fission product elemental group because it is difficult to remove in solvent extraction processes using TBP.

Normal zirconium was added to feed solutions to approximate the anticipated concentration for a given feed solution. Zirconium-95 tracer was also added ( 10 to $20 \mathrm{mCi}$ per 40 liters of feed solution) to permit a rapid determination of zirconium distribution in process stream samples by gamma spectrometric analysis. A GeLi detector was used in the gamma spectrometric procedure to isolate the gamma radiation at the $756-\mathrm{keV}$ energy level (due to $\mathrm{Zr}-95$ ) from the gamma radiation at the $766-\mathrm{keV}$ energy level (due to daughter $\mathrm{Nb}-95$ ). In addition, al1 $\mathrm{Zr}-95$ measurements were normalized to the date and time of a given solvent extraction run.

Complete uranium and thorium recovery is the primary goal of flowsheets developed for HTGR fuel reprocessing. In general, the flowsheets tested herein demonstrated a high degree of zirconium decontamination with greater than $99.9 \%$ uranium and thorium recovery.

Tests with the first cycle Acid-Thorex process indicate that zirconium DFs as high as 75 (thorium basis) and 36 (uranium basis) are achievable in the $1 \mathrm{~A}$ column. Additional decontamination can be obtained in the scrub section if phase ratios and acidities are optimized. In the pilot plant, the DFs across the scrub section (1S) ranged from 1.5 to 40.

\footnotetext{
*Arithmetic zirconium DF is the ratio of zirconium to heavy metal in the feed divided by the ratio of zirconium to heavy metal in the product.
} 
Zirconium typically follows the aqueous phase in the $1 \mathrm{BX}$ and $1 \mathrm{BS}$ columns and, therefore, accompanies the thorium. As a consequence, zirconium-uranium decontamination is enhanced in the partitioning operation. In the present study, $1 \mathrm{BX}$ zirconium-uranium decontamination factors ranged from 3.5 to 140 .

Some zirconium-uranium decontamination occurs in the IC column (DFs to 2.6) due probably to the association of zirconium with unstrippable organic degradation products in the process solvent.

The second and third uranium cycles of the proposed HEU-HRRF flowsheet were also tested for zirconium decontamination. Overall zirconiumuranium DFs attained in these cycles were very high and ranged from $1.6 \times 10^{3}$ to $7.2 \times 10^{4}$, even with shortened scrub sections used in these tests because of pilot plant height limitations (see Tables 1, 2, 3, and A-3 through A-21).

Overall zirconium-uranium DFs for tests performed with two cycles of the modified Purex process ranged from $8.4 \times 10^{3}$ to $1.9 \times 10^{4}$. Most of the decontamination was accomplished in the extraction columns (5A and $6 \mathrm{~A}$ ); however, some additional DF was obtained in the stripping columns ( $5 \mathrm{~B}$ and $6 B$ ).

There is some evidence that the system using the centrifugal contactor (see Section 7.8) gives $250 \%$ higher zirconium DFs than the allpulse column system. This DF improvement could be due to less extraction of zirconium in the high acid end of the centrifugal contactor as a result of lower residence time.

\subsection{SIMULATED SOLVENT DEGRADATION - EFFECTS OF DIBUTYL PHOSPHATE}

Tributyl phosphate (TBP) is subject to degradation due to radiolysis and acid hydrolysis. The primary degradation product is dibutyl phosphate (DBP), although monobuty1 phosphate (MBP) is formed to a lesser extent. 
The presence of TBP degradation products in solvent extraction operations results in deleterious process effects. In the Acid-Thorex process, these effects include:

1. Reduction in partitioning efficiency due to the formation of an acid unstrippable thorium-DBP complex.

2. Loss of fission product decontamination due to the formation of solvent-soluble DBP-fission product complexes, particular1y zirconium, which reduce scrubbing effectiveness.

3. Changes in phase dispersion characteristics in the uranium stripping column (1C) due to precipitation of thorium-DBP at lower stripping acidities.

4. Precipitation of thorium hydroxide in the solvent wash column on contact with the basic (sodium carbonate) wash solution.

Earlier work at GA (Ref. 1) has demonstrated the utility of fluoride ion in reducing the adverse effects of DBP in the Acid-Thorex process. Selective stripping of thorium results on contact of a solvent phase containing thorium-DBP complex with fluoride ion in an aqueous medium. Therefore, the addition of fluoride ion to the $1 \mathrm{BX}$ and $1 \mathrm{CX}$ streams in concentrations of $0.005 \underline{M}$ and $0.001 \underline{M}$, respectively, is recommended.

The radiation effects observed by Richardson (Ref. 5) on the Purex system show a greater loss in zirconium decontamination per unit of radiation damage (watt-hr/liter or g/liter DBP) than does the Acid-Thorex system (Fig. 11, solid line). The reason for this observed difference is that thorium ion forms a stronger DBP complex than does uranyl ion and, therefore, the amount of uncomplexed DBP available for raising the equilibrium distribution coefficient for zirconium is less in the Acid-Thorex process. In the present study, the zirconium decontamination losses measured during the addition of the HRRF projected amount of DBP to the 


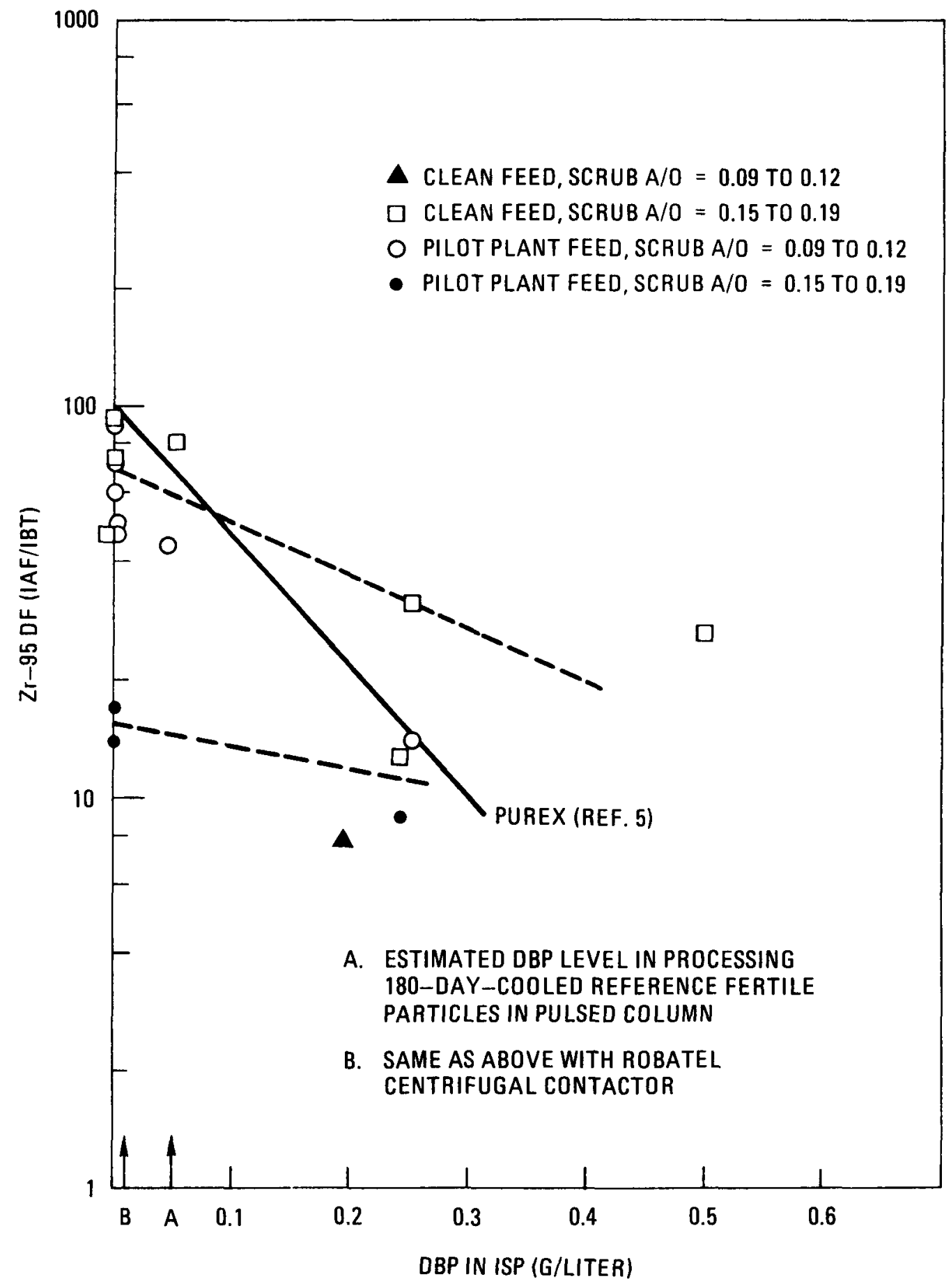

Fig. 11. Measured Zr-95 decontamination factors 
extraction column were so small as to be indistinguishable from the normal experimental variations in the absence of DBP.

The data displayed in Fig. 11 indicate that the scrub section flow rate is a more important variable in $\mathrm{Zr}-95$-thorium separation than the DBP content of the scrub section organic phase. In addition, from these data it is apparent that pilot plant feed (with attendant solids) does not appreciably lower Zr-95-thorium decontamination in the Acid-Thorex process.

In tests of the HEU-HRRF modified Purex flowsheet, the principal manifestation of DBP presence was a marked loss of stripping efficiency in the $5 \mathrm{~B}$ column. Uranium losses via the $5 \mathrm{BW}$ stream increased to about $1 \%$ in the presence of DBP. The calculated height equivalent to a theoretical stage (HETS) value for the 5B stripping column also increased following DBP additions. The above results were due to the formation of a DBP-uranium complex that is difficult to strip, and they occurred in the presence of a greater-than-anticipated amount of DBP in the HRRF Purex flowsheet.

\subsection{CENTRIFUGAL CONTACTOR STUDIES}

A Robatel ${ }^{\circledR}$ centrifugal contactor was used to perform the extraction functions in several HRRF flowsheet tests. The unit evaluated was a Mode1 LX208NSC (see Section 4). The potential advantages of a centrifugal contactor in extraction operations include:

1. Shorter feed-solvent contact time and, therefore, a reduction in solvent degradation due to acid hydrolysis and radiolysis.

2. Small liquid holdup inventory.

3. Decreased startup and shutdown times. 
4. Minimal height requirements.

5. Improved DFs for some fission products due to shorter contact times.

The potential disadvantages associated with centrifugal contactors include:

1. Inability to handle solids, e.g., silicon carbide.

2. Inability to handle the third phase formation characteristic of the $30 \%$ TBP-thorium system at higher solvent thorium loadings (>30 to $35 \mathrm{~g} / 1$ iter).

3. The need for a separate scrub column.

Initial attempts to couple the centrifugal contactor with the pilot plant pulse columns through the use of an airlift resulted in flow control difficulties (see Fig. 12). In addition, the presence of a third phase in the contactor product (1AP) made interface control in the scrub column (1S) difficult. A successful coupling was, however, attained with a contactor product storage tank and a transfer pump (in lieu of the air lift). Third-phase difficulties in the scrub column lower disengaging section were solved through the use of a recirculating pump for phase mixing. A schematic drawing for the operation of the contactor in conjunction with the $1 \mathrm{~S}$ column is given in Fig. 13. Pilot plant operation of the centrifugal contactor in the configuration shown in Fig. 13 is recommended if the contactor is to be used as the primary extraction device. The successful operation of the contactor depends on satisfaction of the following requirements:

1. No restriction in the contactor organic phase outflow--uranium and thorium losses to the aqueous raffinate were observed with $1 \mathrm{AP}$ flow restrictions. 


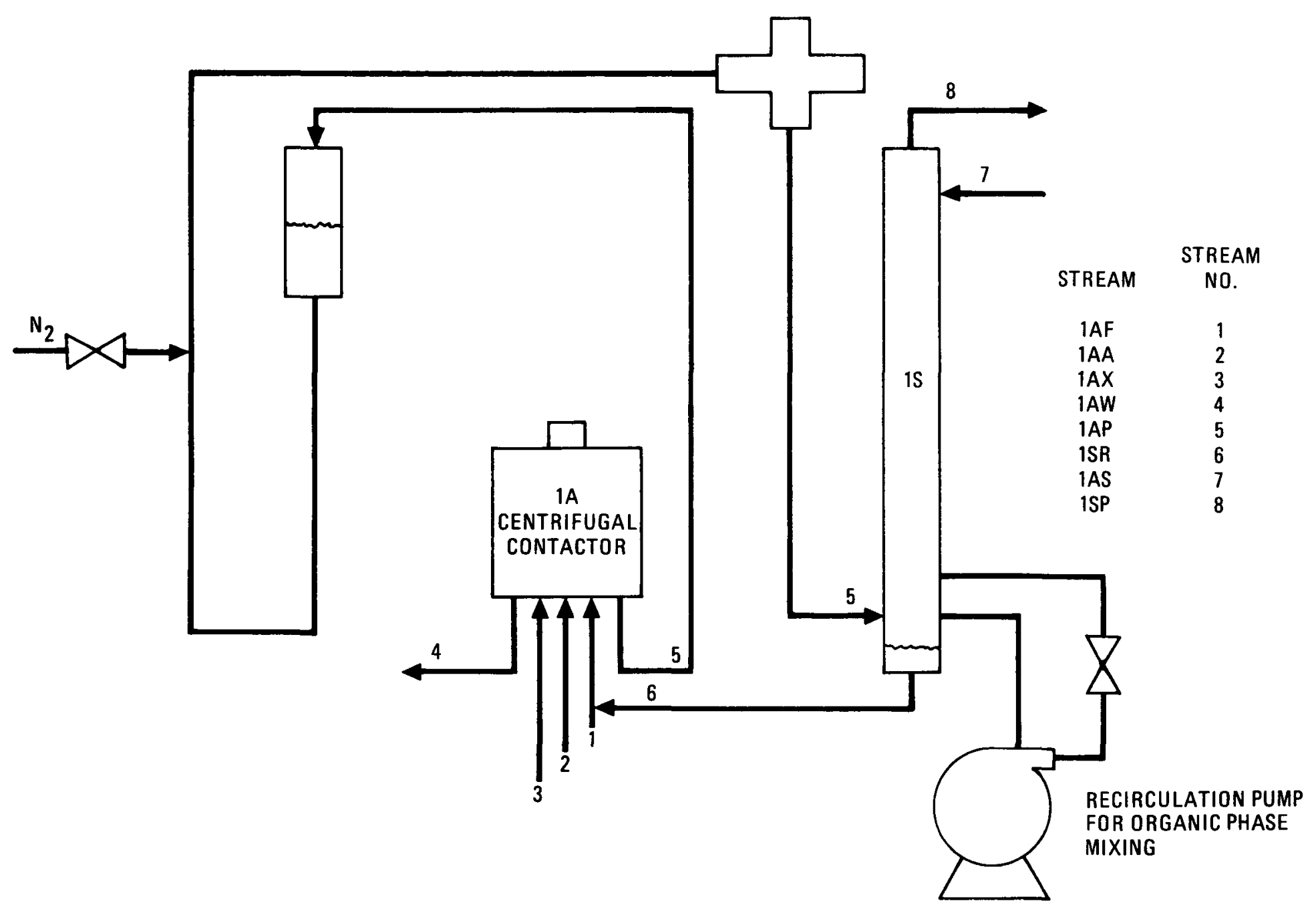

Fig. 12. Centrifugal contactor $1 \mathrm{~A}$ and column $1 \mathrm{~S}$ with airlift transfer 


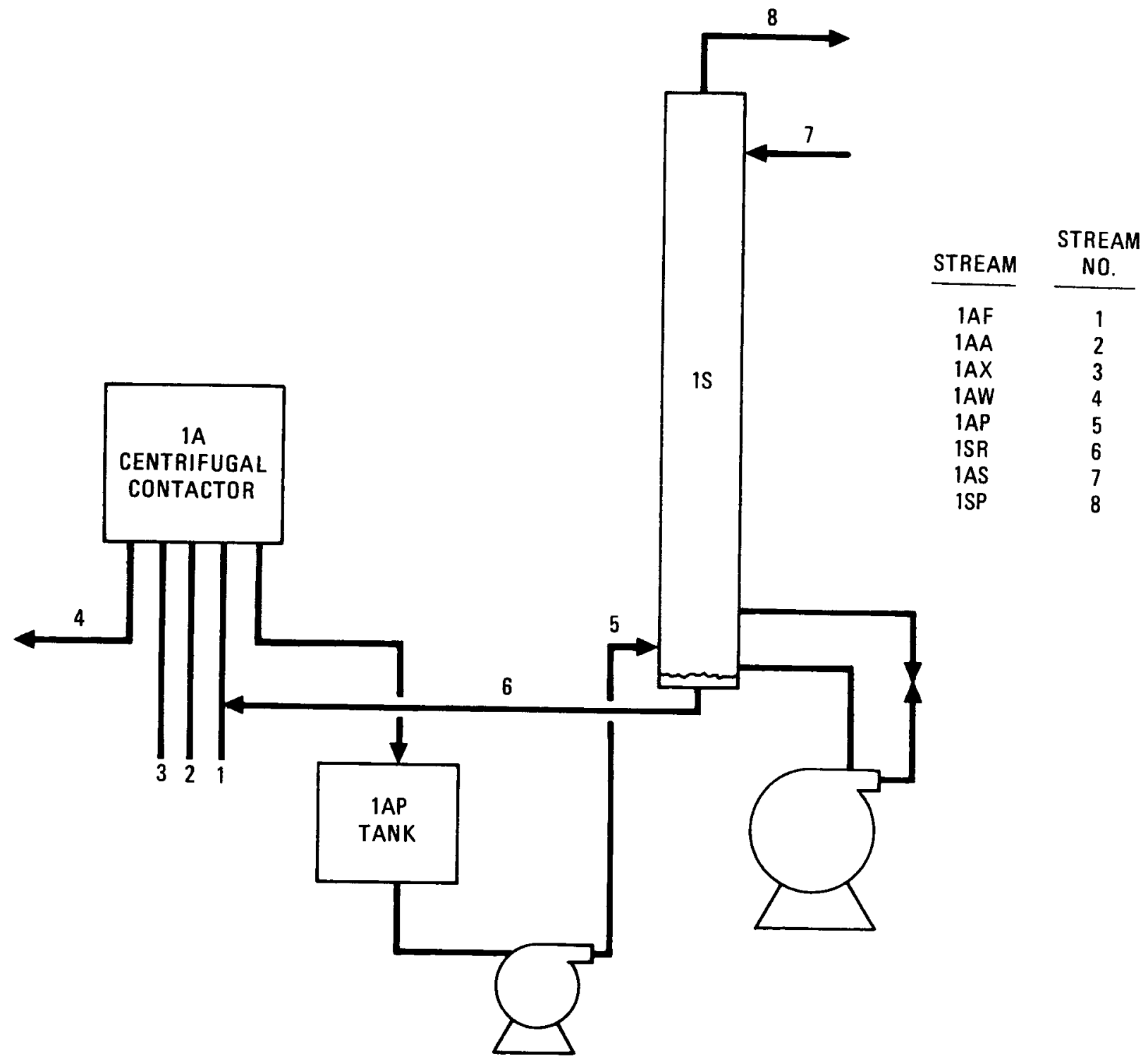

Fig. 13. Centrifugal contactor $1 \mathrm{~A}$ and column $1 \mathrm{~S}$ with $1 \mathrm{AP}$ pump system 
2. Use of a mixing device such as an auxiliary circulating pump to insure mechanical mixing of the organic phase above the scrub column (1S) interface to prevent separation of the third phase (second organic phase).

During operation of the centrifugal contactor, anticipated solids blockage of the aqueous raffinate stream (1AW) was a frequent occurrence.* Blockage of the aqueous transfer ports in the contactor generally resulted in both the aqueous waste stream (1AW) and the product stream (1AP) exiting the contactor via the normal product stream route. In a11 cases of contactor blockage, the plug was successfully removed by flushing with $13 \underline{M}$ nitric acid and increasing the contactor rotating speed.

Extraction efficiency studies for uranium and thorium-30\% TBP/NPH systems were conducted in the pilot plant with the centrifugal contactor. To determine the efficiency of the contactor, the flow rates of the aqueous feed and solvent were adjusted to increase the uranium or thorium loading in the solvent to give measurable losses in the aqueous waste stream. Figures 14 and 15 contain the flowsheet schematic drawings for the thorium and uranium contactor efficiency studies, respectively. The stream flow rate and analytical data for each system are given in the Appendix, Tables A-22 and A-23. The calculated losses and related data for the contactor efficiency studies are presented in the Appendix, Tables A-24 and A-25. Table 7 contains data on the centrifugal contactor and pulse columns used in the efficiency studies.

The SEPHIS computer code (Ref. 18) was used to calculate theoretical values for the effluent streams in the efficiency tests. These values were compared with analytical values obtained from pilot plant samples. Data from these comparisons are presented in the Appendix, Tables A-26 and $\mathrm{A}-27$.

*A Consler Model SPCP-1 in-line filter equipped with a 5-micron filter cartridge was used to remove bulk feed solids prior to centrifugal contactor processing. The unit is available from Consler Mfg. Co., Honeoye Falls, NY 


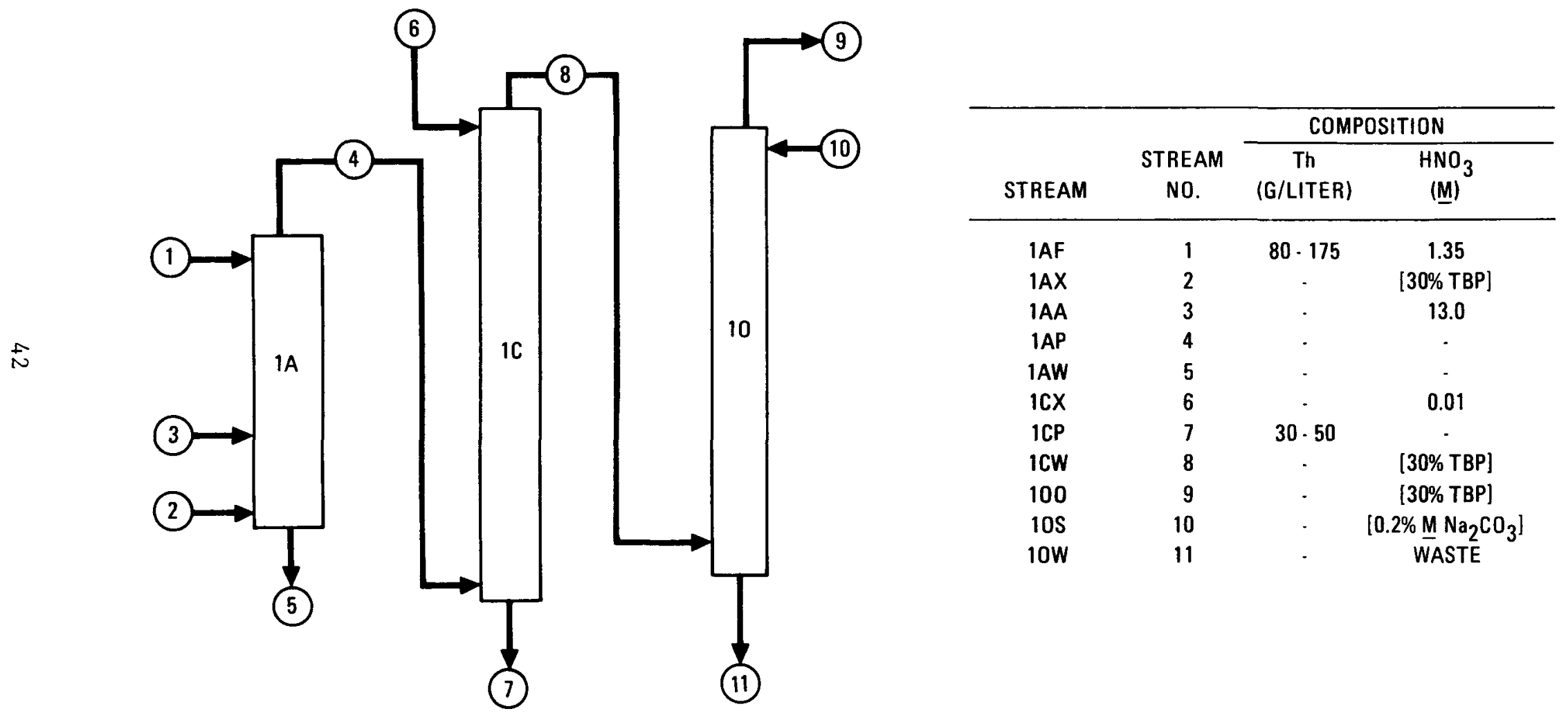

Fig. 14. Centrifugal contactor efficiency study flowsheet: thorium - 30\% TBP system 


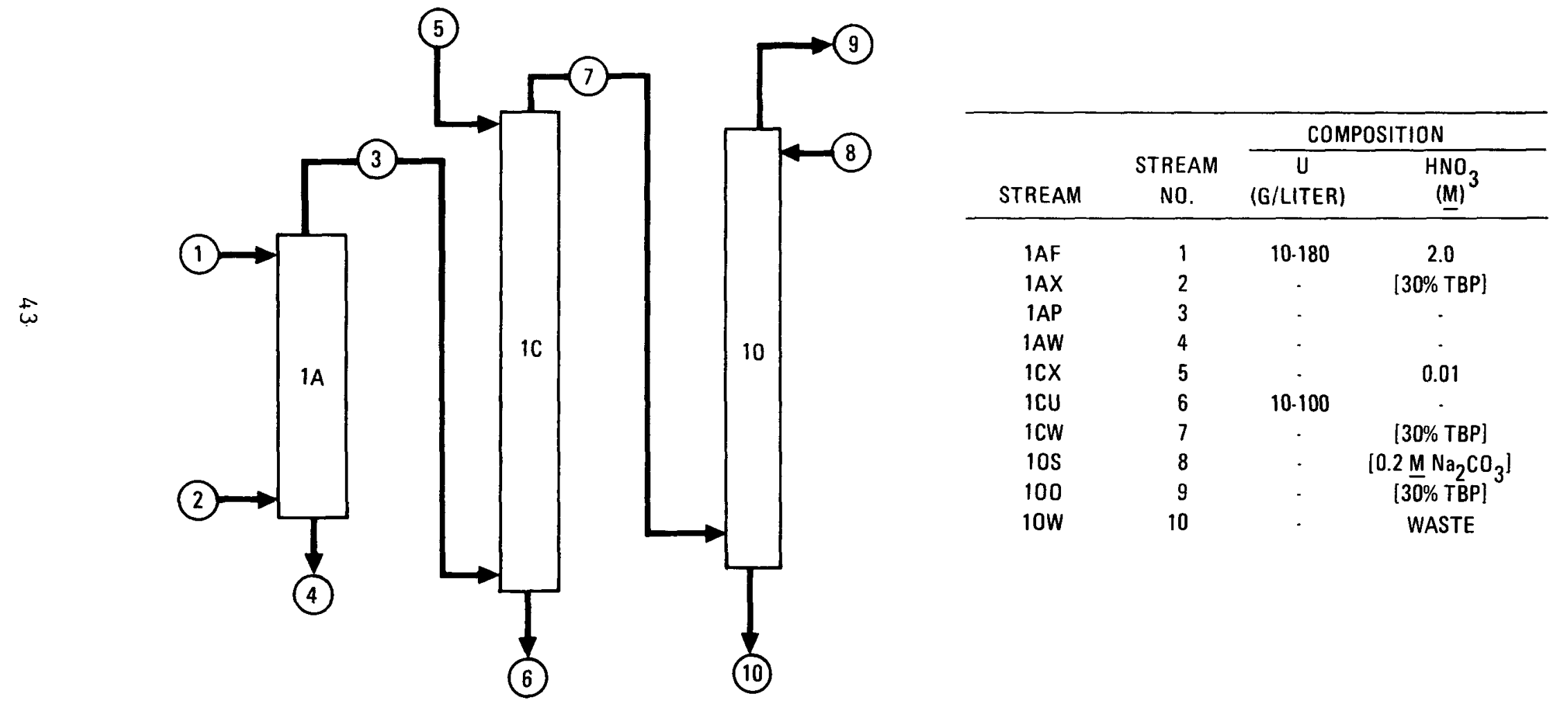

Fig. 15. Centrifugal contactor efficiency study flowsheet: uranium - $30 \%$ TBP system 
TABLE 7

CENTRIFUGAL CONTACTOR AND COLUMN CARTRIDGE DESCRIPTION

\begin{tabular}{|c|c|c|c|c|c|c|c|}
\hline Unit & Purpose & $\begin{array}{l}\text { Diameter } \\
(\mathrm{mm})\end{array}$ & $\begin{array}{l}\text { Total Height } \\
\text { of Mixing } \\
\text { Area } \\
\text { (m) }\end{array}$ & \multicolumn{4}{|c|}{ Other } \\
\hline \multirow[t]{3}{*}{$1 \mathrm{~A}$ contactor } & \multirow[t]{3}{*}{ Extraction } & \multirow[t]{3}{*}{180} & \multirow[t]{3}{*}{0.32} & 8 stages & $\begin{array}{ll}\text { ith } & 0 \\
\text { lup } & p\end{array}$ & $\begin{array}{l}\text { liter } \\
\text { stage }\end{array}$ & total \\
\hline & & & & & tes & & \multirow[b]{2}{*}{$\begin{array}{l}\text { Plate } \\
\text { Spacing } \\
\text { (mm) }\end{array}$} \\
\hline & & & & $\begin{array}{l}\text { Nozzle } \\
\text { Direction }\end{array}$ & $\begin{array}{l}\text { Hole } \\
\text { Size } \\
\text { (mm) }\end{array}$ & $\begin{array}{c}\text { Free } \\
\text { Area } \\
(\%)\end{array}$ & \\
\hline 1C column & U-strip & 76 & 4.6 & Up & 4.8 & 23 & Graded (a) \\
\hline 10 column & Solvent wash & 51 & 5.5 & Down & 3.2 & 23 & 51 \\
\hline
\end{tabular}

(a) Graded cartridge is, from the bottom, $2.6 \mathrm{~m}$ with $100 \mathrm{~mm}$ spacing, $0.5 \mathrm{~m}$ with $76 \mathrm{~mm}$ spacing, and the remainder with $51 \mathrm{~mm}$ spacing. 
The operating efficiency of the contactor for the uranium-30\% TBP/NPH system was found to approach $100 \%$. Typical uranium losses measured were less than predicted by the SEPHIS code. The absolute determination of the centrifugal contactor uranium efficiency is not possible due to known inaccuracy $( \pm 5 \%)$ in the analysis of TBP content in the solvent uncertainties in the SEPHIS code under conditions of high uranium solvent loading, and the uncertainty in the operating temperature within the contactor.

The agreement between the results from the SEPHIS code calculation and the analyses of the end stream samples from the thorium-30\% TBP/NPH runs was not good. One reason for the differences is the uncertainties of the code. The development of the code used correlations which are applicable at conditions of lower solvent loading than used in these tests. In addition, the code does not take into account the three phases which are present at higher thorium concentrations.

Under conditions of near-saturation of the solvent, very erratic thorium values were obtained for the contactor product (1AP). These variations are due to the cyclical nature in which the third phase was built up in the contactor and then released. Part of the release of the third phase may have occurred via the aqueous raffinate (1 AW) stream, which would account for the high and erratic analytical $1 \mathrm{AW}$ values. More likely, the fluctuation in end stream thorium concentrations was caused by intermittent recycle of the heavy solvent phase through the aqueous routing from stage to stage within the centrifugal contactor.

In the first cycle of the Thorex flowsheet, an operation with the thorium loading of the solvent in the third phase region is desirable to permit significant fission product decontamination. In a pulsed column, this desired solvent loading can be achieved without any adverse or uncontrolled losses of thorium. In the centrifugal contactor, however, these same conditions produce unpredictable and significant losses of thorium. Therefore, a centrifugal contactor is not recommended for 
thorium TBP/NPH extraction because of the uneven operation in the presence of a second organic phase (third phase). A compound pulse column with the scrub section attached to the top of the extraction section is recommended for the Acid-Thorex process.

Based on (1) the high efficiency measured for the centrifugal contactor with the uranium-30\% TBP/NPH system and (2) the satisfactory pilot plant performance observed with the contactor in HEU-HRRF modified Purex flowsheets, use of the unit is a feasible alternative to pulsed columns for the initial aqueous-solvent contact in this flowsheet provided a highly efficient feed clarification step is used.

\subsection{EFFECT OF FEED SOLIDS}

Some solid material, e.g., graphite and silicon carbide in quantities of $<0.5$ wt $\%$, are expected to carry through to solvent extraction from head-end operations. Therefore, four runs were conducted in the present study to assess the impact of feed solids on the proposed HEUHRRF Acid-Thorex flowsheet.

The experiments confirm earlier findings (Ref. 1) of a reduction in measured zirconium decontamination. In HRRF Acid-Thorex studies, lower Zr-95 DFs (factors of 2 to 5) were observed across the flowsheet for runs in which feed solutions were prepared from HTGR head-end operations product material.

The impact of feed solids on uranium and thorium losses was found to be small. The extraction column developed flooding at lower relative column throughput rates when solids were present. However, the efficiency of thorium and uranium extraction remained within acceptable limits. The maximum thorium and uranium losses encountered in runs using pilot-plantprepared feed solutions were $0.51 \%$ and $0.05 \%$, respectively. Runs conducted in the absence of feed solids (feeds prepared from purchased materials) gave thorium and uranium losses of $0.04 \%$ and $0.08 \%$, respectively. 


\subsection{ANALYSIS OF STREAM SAMPLES}

Difficult challenges are encountered in the analyses of some stream samples from the HRRF Acid-Thorex process. The 1BT thorium partition product and the $1 \mathrm{CU}$ uranium product are samples that are particularly troublesome from an analytical standpoint. The difficulty is attributable to the extreme ratios present in these samples. The ratio of thorium to uranium in typical $1 \mathrm{BT}$ samples is $22.0 \times 10^{4}$ to 1 . A typical ratio of uranium to thorium in $1 \mathrm{CU}$ samples is $21.5 \times 10^{4}$ to 1 .

Procedures were developed in the current study to permit accurate and rapid measurement of the trace level component in $1 \mathrm{BT}$ and $1 \mathrm{CU}$ samples. These procedures are described in detail in Ref. 14.

7.11. OTHER FUEL CYCLE APPLICABILITY

Work described in the present report addresses the solvent extraction processing of high-enriched uranium (HEU) fuels. The HTGRs developed in the United States have emphasized the use of the Th-U-233 cycle. This cycle uses thorium and 93\% enriched U-235 in the initial and the makeup fuel.

The current uncertainty in regulations affecting nuclear safeguards has resulted in commercialization options for closing the HTGR fuel cycle based on the introduction of early HTGRs on alternate cycles, such as a denatured Th-U-233 stowaway for MEU recycle fuel cycle. This work is generally applicable to these alternate cycles; however, for U/Th ratios that are greatly different than those reported herein, verification is needed.

If MEU fissile particles are processed, the feed to the modified Purex process would have a higher uranium concentration than HEU-derived feed. This increased concentration would be possible because the relative fission product level is less for MEU fuels. In addition, the increased quantity of plutonium present in MEU fissile streams may require isolation of the element as a pure product. 


\subsection{FUTURE WORK}

Future solvent extraction development should include:

1. Additional testing of the second and third uranium cycles for the HRRF Acid-Thorex flowsheet. Further testing is required to optimize A column scrub section lengths in order to attain greater uranium fission product DFs.

2. A pilot plant study for the development of a second thoriumcycle solvent extraction flowsheet for HRRF and evaluation thereof to produce thorium products with less than 10 parts of uranium per million parts of thorium. Included in this study would be an assessment of methods for a separation of plutonium from thorium in the first-cycle thorium partition product (1BT).

3. Optimization of solvent washing and solvent cleanup methods initiated in earlier work at GA (Ref. 1).

4. A study of the effectiveness of ruthenium and zirconium decontamination using the HRRF flowsheets developed. These elements are of concern due to the difficulty of their separation from uranium and thorium.

5. Studies to test the effect of different thorium-to-uranium ratios in the feed solutions for MEU-HRRF flowsheets and the different product requirements of some fuel cycle options.

6. Testing of new pulse column plate designs developed by GA under the Alternate Fuel Cycle Technologies (AFCT) Program. 


\section{ACKNOWLEDGMENTS}

The author acknowledges the direction and assistance of G. E. Benedict, who in addition developed the flowsheets used herein and provided guidance throughout the studies. The contributions of G. W. Reddick* were significant and are duly noted. SEPHIS profiles for several solvent extraction runs were generated and evaluated by D. R. Engler and his assistance is appreciated. L. E. Jolley and M. D. True were responsible for the pilot plant operations and their efforts are gratefully acknowledged. The service provided by the GA Analytical Chemistry Department in performing the required analyses is recognized.

*Presently employed by Rockwe11 Hanford Operations, Richland, Washington. 
APPENDIX

PILOT PLANT OPERATIONAL DATA

The appendix contains data from pilot plant operations. The total height of each column cartridge is given. Throughput rates are reported as both volume velocity and superficial velocity. Volume velocity is the sum of the phase volumes per unit time per cross-sectional area of the column. The superficial velocity is the linear velocity $\left(\bar{V}_{a}\right.$ is the aqueous phase, $\vec{V}_{0}$ is the organic phase) of each phase based on total cross section of the column.

The flooding frequency is given for each volume velocity. The other data in each table were obtained at the percent of flooding frequency as given for each operation.

Fuel product specification data are presented in Tables $A-1$ and $A-2$, pilot plant operational data are given in Tables $\mathrm{A}-3$ through $\mathrm{A}-21$, and data relative to operation of the centrifugal contactor appear in Tables A-22 through A-27. 
TABLE A-1

TENTATIVE URANIUM PRODUCT SPECIFICATION (U-233, U-235) (a)

\begin{tabular}{|c|c|}
\hline Element & $\begin{array}{c}\text { Maximum Concentration } \\
\text { Limit }(\mu \mathrm{g} / \mathrm{g} \mathrm{U})\end{array}$ \\
\hline Aluminum & 75 \\
\hline Calcium plus magnesium & 150 \\
\hline Chlorine plus fluorine & 50 \\
\hline Chromium & 150 \\
\hline Cobalt & 75 \\
\hline Copper & 200 \\
\hline Iron plus chromium & 200 \\
\hline Lead & 200 \\
\hline Manganese & 200 \\
\hline Mo1ybdenum & 200 \\
\hline Nickel & 150 \\
\hline Phosphorus & 200 \\
\hline Silicon & 200 \\
\hline Sulfur & 30 \\
\hline Tantalum & 200 \\
\hline Thorium & 600 \\
\hline Tin & 200 \\
\hline Titanium & 200 \\
\hline Tungsten & 200 \\
\hline Vanadium & 200 \\
\hline Zinc & 200 \\
\hline $\begin{array}{l}\text { Uranium } \\
\mathrm{NO}_{3}^{-} / \text {heavy metal ratio }\end{array}$ & $\begin{array}{l}1.0 \pm 0.5 \mathrm{M} \mathrm{UO}_{2}\left(\mathrm{NO}_{3}\right)_{2} \\
2<\mathrm{NO}_{3}^{-} / \text {heavy metal } \\
<2.5\end{array}$ \\
\hline Boron equivalent & $\begin{array}{l}\leq 20 \mu \mathrm{g} / \mathrm{g} \text { U burnable } \\
\leq 2 \mu \mathrm{g} / \mathrm{g} \mathrm{U} \text { nonburnable }\end{array}$ \\
\hline
\end{tabular}

(a) Data from Ref. 19. 
TABLE A-2

TENTATIVE THORIUM PRODUCT SPECIFICATION FOR STORAGE(a)

\begin{tabular}{l|l}
\hline Thorium & $2.1 \pm 0.1 \mathrm{M} \mathrm{Th}\left(\mathrm{NO}_{3}\right)_{4}$ \\
$\mathrm{NO}_{3}^{-} / \mathrm{Th}$ & $4<\mathrm{NO}_{3}^{-} / \mathrm{Th}<4.5$ \\
Uranium & $<25 \mu \mathrm{g} / \mathrm{g} \mathrm{Th}$ \\
Plutonium & $<10 \mu \mathrm{g} / \mathrm{g} \mathrm{Th}$ \\
\hline
\end{tabular}

(a) Data from Ref. 20. 
TABLE A-3

HRRF ACID-THOREX PROCESS: OPERATING DATA FOR COLUMN 1A (EXTRACTION)

IN 1A-1S TWO-COLUMN SYSTEM

\begin{tabular}{|c|c|c|c|c|c|c|c|c|c|}
\hline \multirow{4}{*}{$\begin{array}{r}\text { Volume } \\
\text { Velocity } \\
\left(\mathrm{gal} / \mathrm{hr} / \mathrm{ft}^{2}\right)\end{array}$} & \multirow{2}{*}{\multicolumn{2}{|c|}{$\begin{array}{l}\text { Superficial } \\
\text { Velocity }(a)\end{array}$}} & \multirow{4}{*}{$\begin{array}{c}\text { Flooding } \\
\text { Frequency } \\
\text { (cycles/min) }\end{array}$} & \multicolumn{6}{|c|}{ Data at Indicated Percent of Flooding } \\
\hline & & & & \multirow{3}{*}{$\begin{array}{l}\text { Aqueous } \\
\text { Organic } \\
\text { Flow } \\
\text { Ratio(b) }\end{array}$} & \multirow{3}{*}{$\begin{array}{l}\text { Percent } \\
\quad \text { of } \\
\text { Flooding } \\
\text { Frequency }\end{array}$} & \multirow{2}{*}{\multicolumn{2}{|c|}{$\begin{array}{c}\text { Percent } \\
\text { Loss }\end{array}$}} & \multirow{3}{*}{$\begin{array}{l}1 \mathrm{AW} \\
\mathrm{HNO}_{3} \\
(\underline{\mathrm{M}})\end{array}$} & \multirow{3}{*}{$\begin{array}{l}\text { 1AP } \\
\text { Th } \\
(\mathrm{g} / \ell)\end{array}$} \\
\hline & \multirow{2}{*}{$\begin{array}{c}\overline{\mathrm{V}}_{\mathrm{a}} \\
(\mathrm{cm} / \mathrm{s})\end{array}$} & \multirow{2}{*}{$\begin{array}{c}\overline{\mathrm{V}}_{\mathrm{O}} \\
(\mathrm{cm} / \mathrm{s})\end{array}$} & & & & & & & \\
\hline & & & & & & $\mathrm{U}$ & $\mathrm{Th}$ & & \\
\hline 933 & 0.245 & 0.810 & 91 & 0.302 & 80 & 0.08 & 0.04 & 1.2 & 39.5 \\
\hline \multirow[t]{2}{*}{949} & 0.245 & 0.840 & 90 & 0.291 & 81 & 0.08 & 0.03 & 1.9 & 39.1 \\
\hline & & 0.840 & 90 & 0.305 & 81 & & 0.03 & 1.9 & 33.3 \\
\hline 942 & 0.257 & 0.808 & 91 & 0.318 & 90 & 0.05 & 0.51 & 1.9 & 53.2 \\
\hline 946 & 0.259 & 0.811 & 90 & 0.317 & 91 & 0.02 & 0.21 & 1.5 & 76.5 \\
\hline 952 & 0.264 & 0.813 & 89 & 0.319 & 92 & 0.01 & 0.08 & 1.5 & 55.7 \\
\hline 871 & 0.24 & 0.74 & 97 & 0.330 & 82 & 0.002 & 0.52 & 1.6 & 55.5 \\
\hline 991 & 0.23 & 0.89 & 87 & 0.264 & 92 & 0.001 & 0.40 & 1.2 & 109 \\
\hline 917 & 0.24 & 0.80 & 93 & 0.295 & 86 & 0.001 & 0.64 & 1.6 & 49.7 \\
\hline 936 & 0.26 & 0.80 & 91 & 0.322 & 90 & 0.17 & 0.04 & 2.0 & 45.2 \\
\hline 904 & 0.26 & 0.76 & 94 & 0.399 & 87 & 0.15 & 0.04 & 2.1 & 51.3 \\
\hline 996 & 0.24 & 0.89 & 86 & 0.271 & 95 & 0.14 & 0.03 & 1.8 & 52.5 \\
\hline 925 & 0.24 & 0.80 & 92 & 0.303 & 86 & 0.15 & 0.05 & 1.5 & 40.0 \\
\hline 861 & 0.19 & 0.78 & 97 & 0.244 & 81 & 0.10 & 0.03 & 1.8 & 49.1 \\
\hline 881 & 0.18 & 0.82 & 96 & 0.216 & 82 & 0.12 & 0.03 & 1.6 & 46.8 \\
\hline
\end{tabular}

Notes: Operating temperature: ambient.

Column data: total cartridge height $=6.7 \mathrm{~m}(22 \mathrm{ft})$; extraction height $=4.0 \mathrm{~m}(13 \mathrm{ft}) ;$

scrub height $=2.8 \mathrm{~m}(9 \mathrm{ft}) ;$ column diameter $=5.1 \mathrm{~cm}(2 \mathrm{in}$.$) .$

Pulse amplitude: $2.5 \mathrm{~cm}$ (1 in.)

(a) $\overline{\mathrm{V}}_{\mathrm{a}}+\overline{\mathrm{V}}_{\mathrm{o}}=\overline{\mathrm{V}}_{\mathrm{t}}$; volume velocity (in gal/hr/ft ${ }^{2}$ ) $=885\left(\overline{\mathrm{V}}_{\mathrm{t}}\right)$.

(b) ${ }_{\text {Ratio of }}^{\mathrm{aAF}+1 \mathrm{AS}+1 \mathrm{AA}}$. 
TABLE A-4

HRRF ACID-THOREX PROCESS: OPERATING DATA FOR COLUMN IS (SCRUB) IN 1A-1S TWO-COLUMN SYSTEM

\begin{tabular}{|c|c|c|c|c|c|c|c|c|c|}
\hline \multirow{4}{*}{$\begin{array}{r}\text { Volume } \\
\text { Velocity } \\
\left(\mathrm{gal} / \mathrm{hr} / \mathrm{ft}^{2}\right) \\
\end{array}$} & \multirow{2}{*}{\multicolumn{2}{|c|}{$\begin{array}{l}\text { Superficial } \\
\text { Velocity(a) }\end{array}$}} & \multirow{4}{*}{$\begin{array}{c}\text { Flooding } \\
\text { Frequency } \\
\text { (cycles/min) } \\
\end{array}$} & \multicolumn{6}{|c|}{ Data at Indicated Percent of Flooding } \\
\hline & & & & \multirow{3}{*}{$\begin{array}{l}\text { Aqueous } \\
\text { Organic } \\
\text { Flow } \\
\text { Ratio (b) }\end{array}$} & \multirow{3}{*}{$\begin{array}{l}\text { Percent } \\
\quad \text { of } \\
\text { Flooding } \\
\text { Frequency }\end{array}$} & \multirow{2}{*}{\multicolumn{2}{|c|}{$\begin{array}{c}\text { Percent Recycle } \\
\text { to } \\
\text { Column 1A } \\
\end{array}$}} & \multirow{3}{*}{$\begin{array}{r}1 \mathrm{SR} \\
\mathrm{HNO}_{3} \\
(\mathrm{M}) \\
\end{array}$} & \multirow{3}{*}{$\begin{array}{l}1 \mathrm{SP} \\
\mathrm{Th} \\
(\mathrm{g} / \mathrm{l})\end{array}$} \\
\hline & \multirow{2}{*}{$\begin{array}{c}\overline{\mathrm{v}}_{\mathrm{a}} \\
(\mathrm{cm} / \mathrm{s})\end{array}$} & \multirow{2}{*}{$\begin{array}{c}\bar{\nabla}_{\mathrm{O}} \\
(\mathrm{cm} / \mathrm{s})\end{array}$} & & & & & & & \\
\hline & & & & & & $\mathrm{U}$ & Th & & \\
\hline 841 & 0.14 & 0.81 & 100 & 0.178 & 82 & 2.72 & 34.9 & 1.20 & 22.97 \\
\hline 885 & 0.16 & 0.84 & 96 & 0.186 & 85 & 3.17 & 41.3 & 1.30 & 35.27 \\
\hline 850 & 0.14 & 0.82 & 96 & 0.190 & 85 & 2.57 & 44.0 & 1.39 & 25.99 \\
\hline 841 & 0.14 & 0.81 & 100 & 0.176 & 85 & 3.31 & 37.8 & 1.08 & 27.38 \\
\hline 850 & 0.15 & 0.81 & 99 & 0.182 & 86 & 4.68 & 34.9 & 0.90 & 31.33 \\
\hline 858 & 0.16 & 0.81 & 98 & 0.188 & 87 & 4.05 & 49.4 & 0.88 & 33.18 \\
\hline 781 & 0.14 & 0.74 & 105 & 0.191 & 77 & 3.43 & 37.2 & 0.98 & 31.79 \\
\hline 894 & 0.12 & 0.89 & 95 & 0.140 & 85 & 2.77 & 16.2 & 1.00 & 38.29 \\
\hline 829 & 0.14 & 0.80 & 101 & 0.170 & 80 & 2.59 & 44.1 & 1.01 & 30.40 \\
\hline 833 & 0.14 & 0.80 & 100 & 0.177 & 84 & 3.00 & 37.3 & 1.23 & 29.93 \\
\hline 800 & 0.14 & 0.76 & 103 & 0.185 & 82 & 3.65 & 46.6 & 1.13 & 29.70 \\
\hline 881 & 0.11 & 0.89 & 95 & 0.123 & 88 & 3.59 & 53.4 & 1.16 & 42.70 \\
\hline 838 & 0.14 & 0.80 & 100 & 0.180 & 83 & 2.49 & 32.7 & 1.21 & 23.67 \\
\hline 769 & 0.09 & 0.78 & 107 & 0.110 & 78 & 2.11 & 24.4 & 1.21 & 23.90 \\
\hline 786 & 0.09 & 0.80 & 105 & 0.109 & 79 & 1.85 & 23.8 & 1.45 & 32.02 \\
\hline
\end{tabular}

Notes: Operating temperature: ambient.

Column data: total cartridge height $=5.5 \mathrm{~m}(18 \mathrm{ft}) ;$ column diameter $=5.1 \mathrm{~cm}(2 \mathrm{in}$.$) .$

Pulse amplitude: $2.5 \mathrm{~cm}$ (1 in.).

(a) $\bar{v}_{a}+\bar{v}_{o}=\bar{v}_{t}$; volume velocity (in gal $\left./ \mathrm{hr} / \mathrm{ft}^{2}\right)=885\left(\overline{\mathrm{V}}_{\mathrm{t}}\right)$.

(b) Ratio of $\frac{1 \mathrm{AS}}{1 \mathrm{AX}}$. 
TABLE A-5

HRRF ACID-THOREX PROCESS: OPERATING DATA FOR

COLUMN 1A-1S SINGLE-COLUMN SYSTEM (EXTRACTION-SCRUB) (SEE FIG. 8)

\begin{tabular}{|c|c|c|c|c|c|c|c|c|c|}
\hline \multirow{4}{*}{$\begin{array}{l}\text { Volume }(\mathrm{a}) \\
\text { Velocity } \\
\left(\mathrm{gal} / \mathrm{hr} / \mathrm{ft}^{2}\right)\end{array}$} & \multirow{2}{*}{\multicolumn{2}{|c|}{$\begin{array}{l}\text { Superficial } \\
\text { Velocity (a) }\end{array}$}} & \multirow{4}{*}{$\begin{array}{c}\text { Flooding } \\
\text { Frequency } \\
\text { (cycles/min) }\end{array}$} & \multicolumn{6}{|c|}{ Data at Indicated Percent of Flooding } \\
\hline & & & & \multirow{3}{*}{$\begin{array}{l}\text { Aqueous } \\
\text { Organic } \\
\text { Flow } \\
\text { Ratio (b) }\end{array}$} & \multirow{3}{*}{$\begin{array}{l}\text { Percent } \\
\text { of } \\
\text { Flooding } \\
\text { Frequency }\end{array}$} & \multirow{2}{*}{\multicolumn{2}{|c|}{$\begin{array}{l}\text { Percent } \\
\text { Loss }\end{array}$}} & \multirow{3}{*}{$\begin{array}{r}1 \mathrm{AW} \\
\mathrm{HNO}_{3} \\
(\mathrm{M})\end{array}$} & \multirow{3}{*}{$\begin{array}{l}\text { 1SP } \\
\text { Th } \\
(g / \ell)\end{array}$} \\
\hline & \multirow{2}{*}{$\begin{array}{c}\overline{\mathrm{V}}_{\mathrm{a}} \\
(\mathrm{cm} / \mathrm{s})\end{array}$} & \multirow{2}{*}{$\begin{array}{c}\bar{V}_{O} \\
(\mathrm{~cm} / \mathrm{s})\end{array}$} & & & & & & & \\
\hline & & & & & & $\mathrm{U}$ & Th & & \\
\hline 915 & 0.25 & 0.78 & 136 & 0.325 & 51 & 0.01 & 1.80 & 2.21 & 53.37 \\
\hline 965 & 0.29 & 0.80 & 134 & 0.360 & 52 & 0.01 & 2.24 & 2.50 & 39.45 \\
\hline
\end{tabular}

Notes: Operating temperature: ambient.

Column data: total cartridge height $=6.7 \mathrm{~m}(22 \mathrm{ft})$; extraction height $=4.6 \mathrm{~m}(15 \mathrm{ft})$; scrub height $=2.1 \mathrm{~m}(7 \mathrm{ft})$; column diameter $=5.1 \mathrm{~cm}$ (2 in.).

Pulse amplitude: $2.5 \mathrm{~cm}$ (1 in.).

(a) $\bar{V}_{a}+\bar{V}_{o}=\bar{V}_{t}$; volume velocity (in gal/hr/ft ${ }^{2}$ ) $=885\left(\bar{V}_{t}\right.$ ).

(b) Ratio of $\frac{1 \mathrm{AF}+1 \mathrm{AS}+1 \mathrm{AA}}{1 \mathrm{AX}}$. 
TABLE A-6

HRRF ACID-THOREX PROCESS: OPERATING DATA FOR COLUMN 1BX (PARTITION) (SEE FIG. 8)

\begin{tabular}{|c|c|c|c|c|c|c|c|c|}
\hline \multirow{3}{*}{$\begin{array}{l}\text { Total } \\
\text { Cartridge } \\
\text { Height(a) } \\
{[\mathrm{m}(\mathrm{ft})]}\end{array}$} & \multirow{3}{*}{$\begin{array}{c}\text { Volume } \\
\text { veloc1ty (b) } \\
\left(\mathrm{ga} / \mathrm{hr} / \mathrm{ft} \mathrm{t}^{2}\right) \\
\end{array}$} & \multirow{2}{*}{\multicolumn{2}{|c|}{$\begin{array}{l}\text { Superficial } \\
\text { Velocity (b) }\end{array}$}} & \multirow{3}{*}{$\begin{array}{c}\text { Flooding } \\
\text { Frequency } \\
\text { (cycles/min) }\end{array}$} & \multicolumn{4}{|c|}{ Data at Indicated Percent of Flooding } \\
\hline & & & & & \multirow{2}{*}{$\begin{array}{l}\text { Aqueous/ } \\
\text { Organic } \\
\text { Flow } \\
\text { Ratio (c) }\end{array}$} & \multirow{2}{*}{$\begin{array}{l}\text { Percent } \\
\text { of } \\
\text { Flooding } \\
\text { Frequency } \\
\end{array}$} & \multirow{2}{*}{$\begin{array}{c}\text { HETS } \\
\text { Thorium } \\
\text { Basis } \\
{[\mathrm{m}(\mathrm{ft})]} \\
\end{array}$} & \multirow{2}{*}{$\begin{array}{l}\text { Arithmetic } \\
\text { Decontamination } \\
\text { Factor for } \\
\text { Uranium (d) }\end{array}$} \\
\hline & & $\begin{array}{c}\vec{v}_{\mathrm{a}} \\
(\mathrm{cm} / \mathrm{s})\end{array}$ & $\begin{array}{c}\bar{v}_{0} \\
(\mathrm{~cm} / \mathrm{s})\end{array}$ & & & & & \\
\hline $4.6(15)$ & 605 & 0.26 & 0.43 & 82 & 0.595 & 82 & $1.15(3.36)$ & 7.5 \\
\hline $4.6(15)(e)$ & 601 & 0.25 & 0.42 & 82 & 0.603 & 85 & $0.97(3.19)$ & 9.5 \\
\hline $4.6(15)(e)$ & 614 & 0.26 & 0.44 & 81 & 0.579 & 85 & $1.08(3.53)$ & 21.3 \\
\hline $4.6(15)$ & 606 & 0.25 & 0.43 & 82 & 0.580 & 79 & $1.01(3.33)$ & 9.4 \\
\hline $4.6(15)(e)$ & 608 & 0.26 & 0.43 & 82 & 0.590 & 67 & $0.95(3.12)$ & 12.4 \\
\hline $4.6(15)(e)$ & 599 & 0.25 & $0.4,3$ & 83 & 0.589 & 66 & $1.01(3.33)$ & 7.7 \\
\hline $4.6(15)$ & 585 & 0.25 & 0.41 & 82 & 0.617 & 60 & $1.86(6.1)$ & 5.3 \\
\hline $4.6(15)(e)$ & 641 & 0.25 & 0.47 & 81 & 0.534 & 60 & & 10.0 \\
\hline $4.6(15)(e)$ & 595 & 0.25 & 0.42 & 81 & 0.582 & 60 & & 6.7 \\
\hline $5.8(19)$ & 618 & 0.25 & 0.45 & 81 & 0.560 & 73 & $1.22(4.0)$ & 6.5 \\
\hline $5.8(19)(e)$ & 597 & 0.25 & 0.43 & 81 & 0.599 & 73 & & 8.6 \\
\hline $5.8(19)(e)$ & 663 & 0.26 & 0.49 & 80 & 0.543 & 74 & & 7.6 \\
\hline $5.8(19)$ & 617 & 0.26 & 0.44 & 82 & 0.587 & 71 & $1.34(4.4)$ & 5.4 \\
\hline $5.8(19)(e)$ & 607 & 0.26 & 0.42 & 81 & 0.619 & 72 & & 7.9 \\
\hline $5.8(19)^{(e)}$ & 608 & 0.27 & 0.41 & 81 & 0.661 & 72 & & 8.4 \\
\hline 5.8 (19) & 572 & 0.25 & 0.40 & 84 & 0.628 & 67 & & 16.2 \\
\hline $5.8(19)$ & 589 & 0.26 & 0.41 & 83 & 0.637 & 80 & & 2.4 \\
\hline $5.8(19)$ & 577 & 0.26 & 0.40 & 84 & 0.644 & 67 & & 6.8 \\
\hline $5.8(19)$ & 590 & 0.25 & 0.42 & 83 & 0.609 & 67 & & 6.3 \\
\hline $5.8(19)$ & 591 & 0.25 & 0.42 & 83 & 0.591 & 67 & & 7.1 \\
\hline $5.8(19)$ & 610 & 0.27 & 0.43 & 82 & 0.625 & 72 & & 7.8 \\
\hline $5.8(19)$ & 608 & 0.26 & 0.43 & 82 & 0.618 & 72 & & \\
\hline $5.8(19)$ & 609 & 0.26 & 0.43 & 82 & 0.618 & 72 & & 8.8 \\
\hline $5.8(19)$ & 612 & 0.27 & 0.43 & 82 & 0.626 & 73 & & 4.9 \\
\hline $5.8(19)(e)$ & 629 & 0.26 & 0.46 & 81 & 0.558 & 74 & & 6.9 \\
\hline $5.8(19)(e)$ & 621 & 0.26 & 0.44 & 82 & 0.596 & 73 & & 7.3 \\
\hline $5.8(19)$ & 608 & 0.26 & 0.43 & 82 & 0.603 & 72 & & 6.6 \\
\hline $5.8(19)$ & 616 & 0.26 & 0.44 & 82 & 0.601 & 72 & & 8.1 \\
\hline 5.8 (19) & 629 & 0.27 & 0.44 & 81 & 0.606 & 73 & & 7.2 \\
\hline $5.8(19)$ & 597 & 0.25 & 0.42 & 82 & 0.603 & 77 & $1.28(4.2)$ & 3.9 \\
\hline 5.8 (19) & 611 & 0.26 & 0.43 & 82 & 0.597 & 77 & $1.28(4.2)$ & 7.1 \\
\hline
\end{tabular}

Notes: Operating temperature: ambient.

Pulse amplitude: $2.5 \mathrm{~cm}$ (1 in.).

(a) Column diameter $=76 \mathrm{~mm}$ (3 in.).

(b) $\overline{\mathrm{v}}_{\mathrm{a}}+\overline{\mathrm{v}}_{\mathrm{o}}=\overline{\mathrm{v}}_{\mathrm{t}}$; volume velocity (In $\left.\mathrm{gal} / \mathrm{hr} / \mathrm{ft}^{2}\right)=885\left(\overline{\mathrm{v}}_{\mathrm{t}}\right)$.

(c) Rat 1o of $\frac{1 \mathrm{BX}}{1 \mathrm{AX}+1 \mathrm{BS}}$.

(d) Arithmetic DF is the ratio of uranium to thorium in the feed divided by the ratio of urantum to thorium in the product.

(e) DBP added to $1 \mathrm{~A}$ column during pilot plant run. 
TABLE $A-7$

HRRF ACID-THOREX PROCESS: OPERATING DATA FOR COLUMN 1BS (PARTITION-SCRUB) (SEE FIG. 8)

\begin{tabular}{|c|c|c|c|c|c|c|c|}
\hline \multirow{3}{*}{$\begin{array}{c}\text { Volume } \\
\text { Velocity (a) } \\
\left(\mathrm{gal} / \mathrm{hr} / \mathrm{ft}^{2}\right)\end{array}$} & \multirow{2}{*}{\multicolumn{2}{|c|}{$\begin{array}{l}\text { Superficial } \\
\text { Velocity }(a)\end{array}$}} & \multirow{3}{*}{$\begin{array}{c}\text { Flooding } \\
\text { Frequency } \\
\text { (cycles/min) }\end{array}$} & \multicolumn{4}{|c|}{ Data at Indicated Percent of Flooding } \\
\hline & & & & \multirow{2}{*}{$\begin{array}{l}\text { Aqueous/ } \\
\text { Organic } \\
\text { Flow } \\
\text { Ratio(b) }\end{array}$} & \multirow{2}{*}{$\begin{array}{l}\quad \text { Percent } \\
\quad \text { of } \\
\text { Flooding } \\
\text { Frequency }\end{array}$} & \multirow{2}{*}{$\begin{array}{c}\text { HETS } \\
\text { Uranium } \\
\text { Basis } \\
{[\mathrm{m}(\mathrm{ft})]}\end{array}$} & \multirow{2}{*}{$\begin{array}{l}\text { Arithmetic } \\
\text { Decontamination } \\
\text { Factor for } \\
\text { Uranium (c) }\end{array}$} \\
\hline & $\begin{array}{c}\overline{\mathrm{V}}_{\mathrm{a}} \\
(\mathrm{cm} / \mathrm{s})\end{array}$ & $\begin{array}{c}\overline{\mathrm{V}}_{\mathrm{O}} \\
(\mathrm{cm} / \mathrm{s}) \\
\end{array}$ & & & & & \\
\hline 644 & 0.57 & 0.15 & 74 & 3.71 & 76 & $0.58(1.89)$ & 222 \\
\hline 610 & 0.57 & 0.11 & 75 & 5.04 & 75 & $0.41(1.36)$ & 40 \\
\hline 652 & 0.58 & 0.17 & 73 & 3.46 & 77 & $0.55(1.79)$ & 148 \\
\hline 649 & 0.57 & 0.17 & 74 & 3.38 & 68 & $0.55(1.79)$ & 1001 \\
\hline 651 & 0.58 & 0.16 & 74 & 3.71 & 68 & $0.50(1.65)$ & 393 \\
\hline 630 & 0.56 & 0.15 & 74 & 3.84 & 68 & $0.61(2.00)$ & 519 \\
\hline 659 & 0.57 & 0.18 & 82 & 3.18 & 66 & & 681 \\
\hline 659 & 0.57 & 0.18 & 82 & 3.21 & 66 & & 2499 \\
\hline 631 & 0.56 & 0.15 & 85 & 3.57 & 64 & & 2002 \\
\hline 682 & 0.56 & 0.21 & 72 & 2.72 & 76 & $1.30(4.25)$ & 36 \\
\hline 674 & 0.57 & 0.19 & 72 & 3.00 & 76 & & 45 \\
\hline 714 & 0.60 & 0.21 & 71 & 2.82 & 77 & & 30 \\
\hline 680 & 0.58 & 0.19 & 72 & 3.10 & 74 & $10.88(2.90)$ & 104 \\
\hline 674 & 0.59 & 0.17 & 72 & 3.46 & 74 & & 81 \\
\hline 658 & 0.62 & 0.13 & 73 & 4.76 & 73 & & 73 \\
\hline 649 & 0.56 & 0.17 & 88 & 3.25 & 57 & & 1656 \\
\hline 643 & 0.58 & 0.14 & 74 & 4.08 & 62 & & 102 \\
\hline 620 & 0.58 & 0.13 & 86 & 4.58 & 70 & & 55 \\
\hline 625 & 0.57 & 0.14 & 85 & 4.09 & 71 & & 37 \\
\hline 630 & 0.56 & 0.15 & 85 & 3.63 & 71 & & 71 \\
\hline 684 & 0.60 & 0.18 & 83 & 3.38 & 63 & & 24 \\
\hline 678 & 0.59 & 0.18 & 83 & 3.38 & 63 & & \\
\hline 675 & 0.59 & 0.17 & 83 & 3.45 & 63 & & 14 \\
\hline 608 & 0.56 & 0.12 & 86 & 4.50 & 63 & & 112 \\
\hline 647 & 0.57 & 0.16 & 84 & 3.64 & 64 & & 298 \\
\hline 713 & 0.59 & 0.22 & 81 & 2.72 & 67 & & 208 \\
\hline 668 & 0.58 & 0.17 & 84 & 3.36 & 63 & & 169 \\
\hline 675 & 0.59 & 0.17 & 83 & 3.38 & 64 & & 407 \\
\hline 707 & 0.60 & 0.20 & 82 & 3.08 & 65 & & 469 \\
\hline 653 & 0.57 & 0.17 & 84 & 3.42 & 69 & $<0.61(<2.0)$ & 1979 \\
\hline 665 & 0.58 & 0.17 & 84 & 3.40 & 69 & $<0.61 \quad(<2.0)$ & 2121 \\
\hline
\end{tabular}

Notes: Operating temperature: ambient.

Column data: total cartridge height $=5.2 \mathrm{~m}(17 \mathrm{ft}) ; \operatorname{column}$ diameter $=5.1 \mathrm{~cm}(2 \mathrm{in}$. Pulse amplitude: $2.5 \mathrm{~cm}$ (1 in.)

(a) $\bar{V}_{a}+\bar{V}_{O}=\bar{V}_{t} ;$ volume velocity (in gal/hr/ft $\left.{ }^{2}\right)=885\left(\bar{V}_{t}\right)$.

(b) Ratio of $\frac{1 \mathrm{BX}}{1 \mathrm{BS}}$.

(c) Arithmetic DF is ratio of uranium to thortum in the feed divided by the ratio of uranium to thorium in the product. 
TABLE A-8

HRRF ACID-THOREX PROCESS: OPERATING DATA FOR COLUMN 1C (U-STRIP) (SEE FIG. 8)

\begin{tabular}{|c|c|c|c|c|c|c|c|c|c|}
\hline \multirow{3}{*}{$\begin{array}{l}\text { Total } \\
\text { Cartridge } \\
\text { Height }(a) \\
{[m(f t)]}\end{array}$} & \multirow{3}{*}{$\begin{array}{c}\text { Volume } \\
\text { Velocity (b) } \\
\text { (gal/hr/ft } \\
\end{array}$} & \multirow{2}{*}{\multicolumn{2}{|c|}{$\begin{array}{l}\text { Superficial } \\
\text { Velocity(b) } \\
\end{array}$}} & \multirow{3}{*}{$\begin{array}{c}\text { Flooding } \\
\text { Frequency } \\
\text { (cycles/m1n) }\end{array}$} & \multicolumn{5}{|c|}{ Data at Indicated Percent of Flooding } \\
\hline & & & & & \multirow{2}{*}{$\begin{array}{c}\text { Aqueous/ } \\
\text { Organic } \\
\text { Flow } \\
\text { Ratio(c) }\end{array}$} & \multirow{2}{*}{$\begin{array}{l}\text { Percent } \\
\text { of } \\
\text { Flooding } \\
\text { Frequency }\end{array}$} & \multirow{2}{*}{$\begin{array}{c}\text { HETS }(d) \\
\text { Uranium } \\
\text { Basis } \\
{[m(f t)]} \\
\end{array}$} & \multirow{2}{*}{$\begin{array}{c}\text { Percent } \\
\text { Urantum } \\
\text { Loss }\end{array}$} & \multirow[b]{2}{*}{$\begin{array}{l}\text { Temp } \\
\left({ }^{\circ} \mathrm{C}\right)\end{array}$} \\
\hline & & $\begin{array}{c}\bar{v}_{\mathrm{a}} \\
(\mathrm{cm} / \mathrm{s}) \\
\end{array}$ & $\begin{array}{c}\bar{v}_{0} \\
(\mathrm{~cm} / \mathrm{s})\end{array}$ & & & & & & \\
\hline $4.6(15)$ & 566 & 0.21 & 0.43 & 85 & 0.493 & 85 & $0.80(2.63)$ & 0.01 & 50 \\
\hline $4.6(15)^{(e)}$ & 565 & 0.22 & 0.42 & 85 & 0.507 & 85 & $0.85(2.80)$ & 0.02 & 50 \\
\hline $4.6(15)^{(e)}$ & 578 & 0.21 & 0.44 & 84 & 0.488 & 86 & $1.17(3.85)$ & 0.28 & 50 \\
\hline $4.6(15)$ & 576 & 0.19 & 0.43 & 85 & 0.478 & 50 & $0.82(2.68)$ & 0.01 & 46 \\
\hline $4.6(15)(e)$ & 575 & 0.20 & 0.43 & 85 & 0.513 & 50 & $0.82(2.68)$ & 0.01 & 46 \\
\hline $4.6(15)^{(e)}$ & 569 & 0.20 & 0.43 & 85 & 0.509 & 50 & & & \\
\hline $4.6(15)$ & 553 & 0.22 & 0.41 & 97 & 0.530 & 77 & & 0.001 & 52 \\
\hline $4.6(15)^{(e)}$ & 601 & 0.21 & 0.47 & 94 & 0.437 & 80 & & 0.087 & 52 \\
\hline $4.6(15)(e)$ & 570 & 0.22 & 0.42 & 96 & 0.515 & 78 & & 0.14 & 52 \\
\hline $4.6(15)$ & 591 & 0.22 & 0.47 & 94 & 0.493 & 73 & & 0.002 & 51 \\
\hline $4.6(15)(e)$ & 565 & 0.21 & 0.43 & 96 & 0.508 & 72 & & 0.002 & 51 \\
\hline $4.6(15)(e)$ & 635 & 0.23 & 0.49 & 92 & 0.473 & 75 & & 0.002 & 51 \\
\hline $4.6(15)$ & 576 & 0.21 & 0.44 & 95 & 0.483 & 75 & & 0.06 & 47 \\
\hline $4.6(15)(e)$ & 564 & 0.21 & 0.42 & 97 & 0.505 & 73 & & 0.27 & 47 \\
\hline $4.6(15)(e)$ & 545 & 0.20 & 0.41 & 97 & 0.490 & 73 & & 0.28 & 47 \\
\hline $4.6(15)$ & 537 & 0.21 & 0.40 & 98 & 0.527 & 67 & & 0.03 & \\
\hline $4.6(15)$ & 553 & 0.22 & 0.41 & 97 & 0.536 & 71 & & 0.03 & 46 \\
\hline $4.6(15)$ & 586 & 0.35 & 0.31 & 95 & 1.13 & 74 & & 0.03 & 47 \\
\hline $4.6(15)$ & 593 & 0.35 & 0.32 & 95 & 1.10 & 74 & & 0.03 & 47 \\
\hline $4.6(15)$ & 673 & 0.41 & 0.35 & 90 & 1.18 & 78 & & 0.03 & 47 \\
\hline $4.6(15)$ & 541 & 0.22 & 0.40 & 98 & 0.541 & 66 & & 0.06 & 53 \\
\hline $4.6(15)$ & 554 & 0.21 & 0.41 & 97 & 0.512 & 67 & & 0.02 & 53 \\
\hline $4.6(15)$ & 567 & 0.21 & 0.43 & 96 & 0.527 & 68 & & 0.02 & 53 \\
\hline $4.6(15)$ & 564 & 0.21 & 0.43 & 86 & 0.501 & 81 & & 0.49 & 53 \\
\hline $4.6(15)$ & 564 & 0.21 & 0.43 & 86 & 0.500 & 81 & & & 53 \\
\hline $4.6(15)$ & 563 & 0.21 & 0.43 & 86 & 0.495 & 81 & & 0.08 & 53 \\
\hline $4.6(15)$ & 532 & 0.20 & 0.40 & 98 & 0.507 & 72 & & 1.22 & 49 \\
\hline $4.6(15)(e)$ & 591 & 0.21 & 0.46 & 94 & 0.463 & 76 & & 10.29 & 49 \\
\hline $4.6(15)(e)$ & 557 & 0.19 & 0.44 & 96 & 0.433 & 74 & & 6.29 & 49 \\
\hline $4.6(15)$ & 571 & 0.22 & 0.43 & 95 & 0.504 & 69 & & 1.22 & 52 \\
\hline $4.6(15)$ & 575 & 0.22 & 0.44 & 95 & 0.495 & 69 & & 2.01 & 52 \\
\hline $4.6(15)$ & 588 & 0.22 & 0.44 & 94 & 0.502 & 70 & & 1.39 & 52 \\
\hline $4.6(15)$ & 842 & 0.48 & 0.47 & 79 & 1.02 & 89 & & 0.03 & 46 \\
\hline $4.6(15)$ & 778 & 0.43 & 0.45 & 83 & 0.953 & 89 & & 0.02 & 46 \\
\hline $4.6(15)$ & 780 & 0.44 & 0.44 & 83 & 0.994 & 84 & & 0.02 & 42 \\
\hline $4.6(15)$ & 825 & 0.42 & 0.51 & 80 & 0.831 & 88 & & & 42 \\
\hline $4.6(15)$ & 860 & 0.47 & 0.50 & 78 & 0.929 & 90 & & 0.05 & 42 \\
\hline $4.6(15)$ & 799 & 0.44 & 0.46 & 82 & 0.969 & 78 & & 0.03 & 47 \\
\hline $4.6(15)$ & 821 & 0.44 & 0.48 & 80 & 0.916 & 80 & & 0.02 & 47 \\
\hline $4.6(15)$ & 558 & 0.21 & 0.42 & 96 & 0.499 & 75 & $0.91(3.0)$ & 0.01 & 47 \\
\hline $4.6(15)$ & 570 & 0.21 & 0.43 & 95 & 0.491 & 76 & $0.91(3.0)$ & 0.01 & 47 \\
\hline
\end{tabular}

Note: Pulse amp1itude: $2.5 \mathrm{~cm}$ (1 in.).

(a) Column diameter $=76 \operatorname{mm}$ ( 3 in.).

(b) $\bar{v}_{a}+\bar{v}_{o}=\bar{v}_{t} ;$ volume velocity $\left(\right.$ in ga1/hr/ft $\left.{ }^{2}\right)=885\left(\bar{v}_{t}\right)$.

(c) Ratio of $\frac{1 \mathrm{CX}}{1 \mathrm{AX}+1 \mathrm{BS}}$.

(d) In cases where no HETS value is given, column functioned in service capacity oniy.

(e) DBP added to $1 \mathrm{~A}$ column during pilot plant run. 
TABLE A-9

HRRF ACID-THOREX PROCESS: OPERATING DATA FOR CENTRIFUGAL CONTACTOR 1A (EXTRACTION) (SEE FIG. 13)

\begin{tabular}{|c|c|c|c|}
\hline \multirow{2}{*}{$\begin{array}{c}\text { Aqueous/ } \\
\text { Organic } \\
\text { Flow } \\
\text { Ratio(a) }\end{array}$} & \multicolumn{2}{|c|}{$\begin{array}{c}\text { Percent } \\
\text { Loss }\end{array}$} & \multirow{2}{*}{$\begin{array}{l}\text { Operating } \\
\text { Speed } \\
\text { (rpm) }\end{array}$} \\
\hline & $\mathrm{U}$ & Th & \\
\hline 0.342 & 0.04 & 0.01 & 1850 \\
\hline 0.309 & 0.13 & 0.05 & 2070 \\
\hline 0.337 & 0.01 & 0.005 & 1200 \\
\hline 0.335 & 0.01 & 0.005 & 1200 \\
\hline 0.305 & 0.02 & 0.005 & 2300 \\
\hline 0.330 & 0.11 & 0.02 & 1200 \\
\hline 0.305 & 0.12 & 0.02 & 1200 \\
\hline 0.310 & 0.09 & 0.02 & 1200 \\
\hline 0.319 & 0.30 & 0.17 & 1200 \\
\hline 0.325 & 0.31 & 0.43 & 1200 \\
\hline 0.332 & 0.28 & 0.41 & 1200 \\
\hline 0.286 & 0.01 & 0.01 & 1200 \\
\hline 0.285 & 0.01 & 0.56 & 1200 \\
\hline 0.304 & 0.02 & 0.14 & 2200 \\
\hline 0.319 & 0.02 & 0.76 & 1200 \\
\hline 0.305 & 0.02 & 0.27 & 1200 \\
\hline 0.254 & 0.01 & 0.10 & 1200 \\
\hline 0.248 & 0.01 & 0.01 & 1200 \\
\hline 0.256 & 0.01 & 0.01 & 1200 \\
\hline 0.268 & 0.01 & 0.01 & 1200 \\
\hline 0.257 & 0.02 & 0.01 & 1200 \\
\hline 0.274 & 0.02 & 0.01 & 1200 \\
\hline 0.276 & 0.02 & 0.02 & 1200 \\
\hline 0.297 & 0.02 & 0.02 & 1200 \\
\hline
\end{tabular}

Notes: Flooding speed for the contactor $=<500 \mathrm{rpm}$.

Number of contactor stages $=8$.

(a) Ratio of $\frac{1 \mathrm{AF}+1 \mathrm{AA}+1 \mathrm{AS}}{1 \mathrm{AX}}$. 
TABLE A-10

HRRF ACID-THOREX PROCESS: OPERATING DATA FOR COLUMN IS IN CENTRIFUGAL CONTACTOR (1A) - 1S SYSTEM (SEE FIG. 13)

\begin{tabular}{|c|c|c|c|c|c|c|c|c|c|}
\hline \multirow{4}{*}{$\begin{array}{c}\text { Volume } \\
\text { Velocity (a) } \\
\left(\mathrm{gal} / \mathrm{hr} / \mathrm{ft} \mathrm{t}^{2}\right)\end{array}$} & \multirow{2}{*}{\multicolumn{2}{|c|}{$\begin{array}{l}\text { Superficial } \\
\text { Veloctty }(a)\end{array}$}} & \multirow{4}{*}{$\begin{array}{c}\text { Flooding } \\
\text { Frequency } \\
\text { (cycles/min) }\end{array}$} & \multicolumn{6}{|c|}{ Data at Indicated Percent of Flooding } \\
\hline & & & & \multirow{3}{*}{$\begin{array}{c}\text { Aqueous/ } \\
\text { Organic } \\
\text { Flow } \\
\text { Ratio(b) }\end{array}$} & \multirow{3}{*}{$\begin{array}{l}\text { Percent } \\
\quad \text { of } \\
\text { Flooding } \\
\text { Frequency }\end{array}$} & \multirow{2}{*}{\multicolumn{2}{|c|}{$\begin{array}{l}\text { Percent } \\
\text { Recycle } \\
\text { to } 1 \mathrm{~A}\end{array}$}} & \multirow{3}{*}{$\begin{array}{r}1 \mathrm{SR} \\
\mathrm{HNO}_{3} \\
(\mathrm{M}) \\
\end{array}$} & \multirow{3}{*}{$\begin{array}{l}\text { 1SP } \\
\text { Th } \\
(\mathrm{g} / \ell)\end{array}$} \\
\hline & \multirow{2}{*}{$\begin{array}{c}\overline{\mathrm{V}}_{\mathrm{a}} \\
(\mathrm{cm} / \mathrm{s})\end{array}$} & \multirow{2}{*}{$\begin{array}{c}\overline{\mathrm{V}}_{\mathrm{O}} \\
(\mathrm{cm} / \mathrm{s})\end{array}$} & & & & & & & \\
\hline & & & & & & $\mathrm{U}$ & Th & & \\
\hline 767 & 0.15 & 0.72 & 105 & 0.202 & 76 & 2.40 & 31.9 & 1.49 & 13.92 \\
\hline 810 & 0.14 & 0.77 & 101 & 0.186 & 80 & 3.53 & 36.7 & 1.08 & 16.24 \\
\hline 748 & 0.15 & 0.70 & 109 & 0.208 & 62 & 3.28 & 38.1 & 1.37 & 23.21 \\
\hline 765 & 0.15 & 0.72 & 106 & 0.205 & 64 & 4.54 & 64.9 & 1.44 & 34.81 \\
\hline 818 & 0.14 & 0.79 & 102 & 0.178 & 59 & 3.66 & 41.1 & 1.71 & 23.21 \\
\hline 810 & 0.15 & 0.77 & 101 & 0.193 & 79 & 6.80 & 66.7 & 1.74 & 25.53 \\
\hline 829 & 0.14 & 0.79 & 100 & 0.181 & 72 & 6.43 & 65.9 & 1.74 & 27.85 \\
\hline 826 & 0.14 & 0.79 & 101 & 0.181 & 71 & 7.49 & 82.9 & 1.74 & 27.85 \\
\hline 820 & 0.15 & 0.78 & 101 & 0.191 & 79 & 3.98 & 35.2 & 1.82 & 23.21 \\
\hline 820 & 0.15 & 0.78 & 101 & 0.188 & 79 & & & & \\
\hline 824 & 0.15 & 0.79 & 101 & 0.186 & 72 & 2.89 & 33.5 & 1.86 & 30.17 \\
\hline 805 & 0.14 & 0.76 & 102 & 0.286 & 81 & 1.92 & 22.6 & 1.63 & 25.53 \\
\hline 899 & 0.15 & 0.87 & 94 & 0.285 & 88 & 1.79 & 21.2 & 1.65 & 23.21 \\
\hline 811 & 0.14 & 0.77 & 102 & 0.304 & 81 & 4.53 & 73.8 & 1.72 & 27.85 \\
\hline 828 & 0.14 & 0.79 & 101 & 0.183 & 83 & 2.73 & 28.5 & 1.58 & 27.85 \\
\hline 841 & 0.15 & 0.80 & 99 & 0.182 & 72 & 4.00 & 37.8 & 1.76 & 30.17 \\
\hline 788 & 0.09 & 0.80 & 105 & 0.113 & 68 & 1.93 & 24.0 & 2.04 & 34.81 \\
\hline 1008 & 0.15 & 0.90 & 86 & 0.148 & 93 & 4.47 & 17.3 & 2.23 & 23.21 \\
\hline 968 & 0.15 & 0.94 & 89 & 0.157 & 90 & 1.65 & 10.1 & 2.46 & 27.85 \\
\hline 935 & 0.15 & 0.91 & 91 & 0.166 & 90 & 5.96 & 10.2 & 1.79 & 25.53 \\
\hline 1064 & 0.15 & 1.05 & 82 & 0.146 & & 3.14 & 27.9 & 1.64 & 164.7 \\
\hline 1036 & 0.15 & 1.01 & 84 & 0.159 & & 2.37 & 13.3 & 1.64 & 32.49 \\
\hline 974 & 0.16 & 0.93 & 90 & 0.17 & 77 & 2.35 & 32.9 & 2.16 & 27.85 \\
\hline 1015 & 0.16 & 0.99 & 86 & 0.16 & 55 & 2.23 & 29.1 & 1.78 & 30.17 \\
\hline
\end{tabular}

Notes: Column data: total cartridge helght $=6.7 \mathrm{~m}(22 \mathrm{ft})$; $\operatorname{column}$ diameter $=5.1 \mathrm{~cm}(2 \mathrm{in}$. Operating temperature: ambient.

Pulse amplitude: $2.5 \mathrm{~cm}$ ( 1 in.).

(a) $\vec{v}_{a}+\vec{v}_{o}=\vec{V}_{t}$; volume velocity (in gal/hr/ft $\left.{ }^{2}\right)=885\left(\bar{v}_{t}\right)$.

(b) Ratio of $\frac{1 \mathrm{AS}}{1 \mathrm{AX}}$. 
TABLE A-11

HRRF ACID-THOREX PROCESS: OPERATING DATA FOR COLUMN 2A (EXTRACTION) (SEE FIG. 8)

\begin{tabular}{|c|c|c|c|c|c|c|c|}
\hline \multirow{3}{*}{$\begin{array}{c}\text { Volume } \\
\text { Velocity (a) } \\
\left.\text { (gal/hr/ft }{ }^{2}\right)\end{array}$} & \multirow{2}{*}{\multicolumn{2}{|c|}{$\begin{array}{l}\text { Superficial } \\
\text { Velocity (a) }\end{array}$}} & \multirow{3}{*}{$\begin{array}{c}\text { Flooding } \\
\text { Frequency } \\
\text { (cycles/min) }\end{array}$} & \multicolumn{4}{|c|}{ Data at Indicated Percent of Flooding } \\
\hline & & & & \multirow{2}{*}{$\begin{array}{c}\text { Aqueous/ } \\
\text { Organic } \\
\text { Flow } \\
\text { Ratio(b) }\end{array}$} & \multirow{2}{*}{$\begin{array}{l}\text { Percent } \\
\text { Uranium } \\
\text { Loss }\end{array}$} & \multirow{2}{*}{$\begin{array}{l}\text { Percent } \\
\quad \text { of } \\
\text { Flooding } \\
\text { Frequency }\end{array}$} & \multirow[b]{2}{*}{$\begin{array}{c}\text { HETS } \\
{[\mathrm{m}(\mathrm{ft})]}\end{array}$} \\
\hline & $\begin{array}{c}\overline{\mathrm{V}}_{\mathrm{a}} \\
(\mathrm{cm} / \mathrm{s})\end{array}$ & $\begin{array}{c}\overline{\mathrm{V}}_{\mathrm{O}} \\
(\mathrm{cm} / \mathrm{s})\end{array}$ & & & & & \\
\hline \multirow[t]{2}{*}{939} & \multirow[t]{2}{*}{0.996} & \multirow[t]{2}{*}{0.066} & 101 & \multirow[t]{2}{*}{4.17} & \multirow[t]{2}{*}{0.68} & \multirow[t]{2}{*}{77} & $1.44(4.71)$ \\
\hline & & & 101 & & & & $1.40(4.59)$ \\
\hline 950 & 0.849 & 0.225 & 101 & 3.77 & 0.025 & \multirow[t]{2}{*}{79} & $1.34(4.41)$ \\
\hline 947 & 0.852 & 0.219 & 101 & 3.89 & 0.009 & & $1.12(3.66)$ \\
\hline \multirow[t]{2}{*}{934} & \multirow[t]{2}{*}{0.841} & \multirow[t]{2}{*}{0.215} & 101 & \multirow[t]{2}{*}{3.91} & 0.035 & \multirow[t]{2}{*}{65} & $1.05(3.43)$ \\
\hline & & & 101 & & 0.043 & & $1.06(3.49)$ \\
\hline \multirow[t]{2}{*}{950} & \multirow[t]{2}{*}{0.857} & \multirow[t]{2}{*}{0.217} & 101 & \multirow[t]{2}{*}{3.95} & 0.040 & \multirow[t]{2}{*}{81} & $1.04(3.41)$ \\
\hline & & & 101 & & 0.048 & & $1.33(4.36)$ \\
\hline \multirow[t]{2}{*}{948} & \multirow[t]{2}{*}{0.882} & \multirow[t]{2}{*}{0.220} & 101 & \multirow[t]{2}{*}{4.01} & 0.027 & \multirow[t]{2}{*}{79} & $0.87 \quad(2.86)$ \\
\hline & & & & & 0.007 & & $0.79(2.60)$ \\
\hline
\end{tabular}

Notes: Operating temperature: ambient.

Column data: total cartridge height $=6.7 \mathrm{~m}(22 \mathrm{ft})$; extraction height $=4.0 \mathrm{~m}(13 \mathrm{ft})$; scrub height $=2.7 \mathrm{~m}(9 \mathrm{ft})$; column diameter $=5.1 \mathrm{~cm}$ (2 in.).

Pulse amplitude: $2.5 \mathrm{~cm}$ (1 in.)

(a) $\overline{\mathrm{v}}_{\mathrm{a}}+\overline{\mathrm{v}}_{\mathrm{o}}=\overline{\mathrm{v}}_{\mathrm{t}}$; volume velocity (in gal $\left./ \mathrm{hr} / \mathrm{ft}^{2}\right)=885\left(\overline{\mathrm{V}}_{\mathrm{t}}\right)$.

(b) Ratio of $\frac{2 \mathrm{AF}+2 \mathrm{AS}}{2 \mathrm{AX}}$. 
TABLE A-12

HRRF ACID-THOREX PROCESS: OPERATING DATA FOR COLUMN 2B (STRIP) (SEE FIG. 8)

\begin{tabular}{|c|c|c|c|c|c|c|c|c|c|}
\hline \multirow{3}{*}{$\begin{array}{c}\text { Volume } \\
\text { Velocity (a) } \\
\left(\mathrm{gal} / \mathrm{hr} / \mathrm{ft}^{2}\right) \\
\end{array}$} & \multirow{2}{*}{\multicolumn{2}{|c|}{$\begin{array}{l}\text { Superficial } \\
\text { Velocity }(a)\end{array}$}} & \multirow{3}{*}{$\begin{array}{c}\text { Flooding } \\
\text { Frequency } \\
\text { (cycles/min) }\end{array}$} & \multicolumn{6}{|c|}{ Data at Indicated Percent of Flooding } \\
\hline & & & & \multirow{2}{*}{$\begin{array}{c}\text { Aqueous } \\
\text { Organic } \\
\text { Flow } \\
\text { Ratio (b) }\end{array}$} & \multirow{2}{*}{$\begin{array}{l}\text { Percent } \\
\text { Uranium } \\
\text { Loss }\end{array}$} & \multirow{2}{*}{$\begin{array}{c}\text { Thorium } \\
\text { DF } \\
\text { Uranium } \\
\text { Basis (c) }\end{array}$} & \multirow{2}{*}{$\begin{array}{l}\text { Percent } \\
\text { Flooding } \\
\text { Frequency }\end{array}$} & \multirow[b]{2}{*}{$\begin{array}{c}\text { HETS } \\
{[\mathrm{m}(\mathrm{ft})]}\end{array}$} & \multirow[b]{2}{*}{$\begin{array}{l}\text { Temp } \\
\left({ }^{\circ} \mathrm{C}\right)\end{array}$} \\
\hline & $\begin{array}{c}\overline{\mathrm{V}}_{\mathrm{a}} \\
(\mathrm{cm} / \mathrm{s})\end{array}$ & $\begin{array}{c}\overline{\mathrm{V}}_{\mathrm{O}} \\
(\mathrm{cm} / \mathrm{s})\end{array}$ & & & & & & & \\
\hline 296 & 0.129 & 0.206 & 89 & 0.63 & 0.973 & 588 & 72 & & 50 \\
\hline 460 & 0.296 & 0.225 & 98 & 1.31 & 0.019 & 2.61 & 88 & $1.56(5.12)$ & 50 \\
\hline 461 & 0.303 & 0.219 & 98 & 1.39 & 0.004 & 2.13 & 88 & $1.53(5.02)$ & 50 \\
\hline \multirow[t]{2}{*}{396} & \multirow[t]{2}{*}{0.233} & \multirow[t]{2}{*}{0.215} & \multirow[t]{2}{*}{98} & \multirow[t]{2}{*}{1.00} & 0.002 & & 82 & $1.31(4.31)$ & 50 \\
\hline & & & & & 0.002 & & 82 & $1.31(4.31)$ & 50 \\
\hline \multirow[t]{2}{*}{378} & \multirow[t]{2}{*}{0.210} & \multirow[t]{2}{*}{0.217} & \multirow[t]{2}{*}{108} & \multirow[t]{2}{*}{0.97} & 0.006 & 13.0 & 80 & $1.14(3.76)$ & 50 \\
\hline & & & & & 0.006 & 14.8 & 80 & $1.14(3.76)$ & 50 \\
\hline \multirow[t]{2}{*}{384} & \multirow[t]{2}{*}{0.214} & \multirow[t]{2}{*}{0.220} & \multirow[t]{2}{*}{122} & \multirow[t]{2}{*}{0.97} & 0.004 & 24.7 & 79 & $1.15(3.77)$ & 50 \\
\hline & & & & & 0.002 & 18.5 & 79 & $1.14(3.76)$ & 50 \\
\hline
\end{tabular}

Notes: Column data: total cartridge height $=4.6 \mathrm{~m}(15 \mathrm{ft}) ;$ column diameter $=5.1 \mathrm{~cm}(2 \mathrm{in}$.$) .$

Pulse amplitude: $2.5 \mathrm{~cm}$ ( 1 in.) with exception of data corresponding to a volume velocity of $296 \mathrm{gal} / \mathrm{hr} / \mathrm{ft}^{2}$, which was $3.8 \mathrm{~cm}(1.5 \mathrm{in.})$ amplitude.

(a) $\overline{\mathrm{v}}_{\mathrm{a}}+\overline{\mathrm{V}}_{\mathrm{o}}=\overline{\mathrm{V}}_{\mathrm{t}}$; volume velocity (in gal/hr/ft $\left.{ }^{2}\right)=885\left(\overline{\mathrm{V}}_{\mathrm{t}}\right)$.

(b) Ratio of $\frac{2 \mathrm{BX}}{2 \mathrm{AX}}$.

(c) Arithmetic DF is ratio of thorium to uranium in the feed divided by the ratio of thorium to uranium in the product ( $2 \mathrm{AF} / 2 \mathrm{BU})$. 
TABLE A-13

HRRF ACID-THOREX PROCESS: OPERATING DATA FOR COLUMN 3A (EXTRACTION) (SEE FIG, 8)

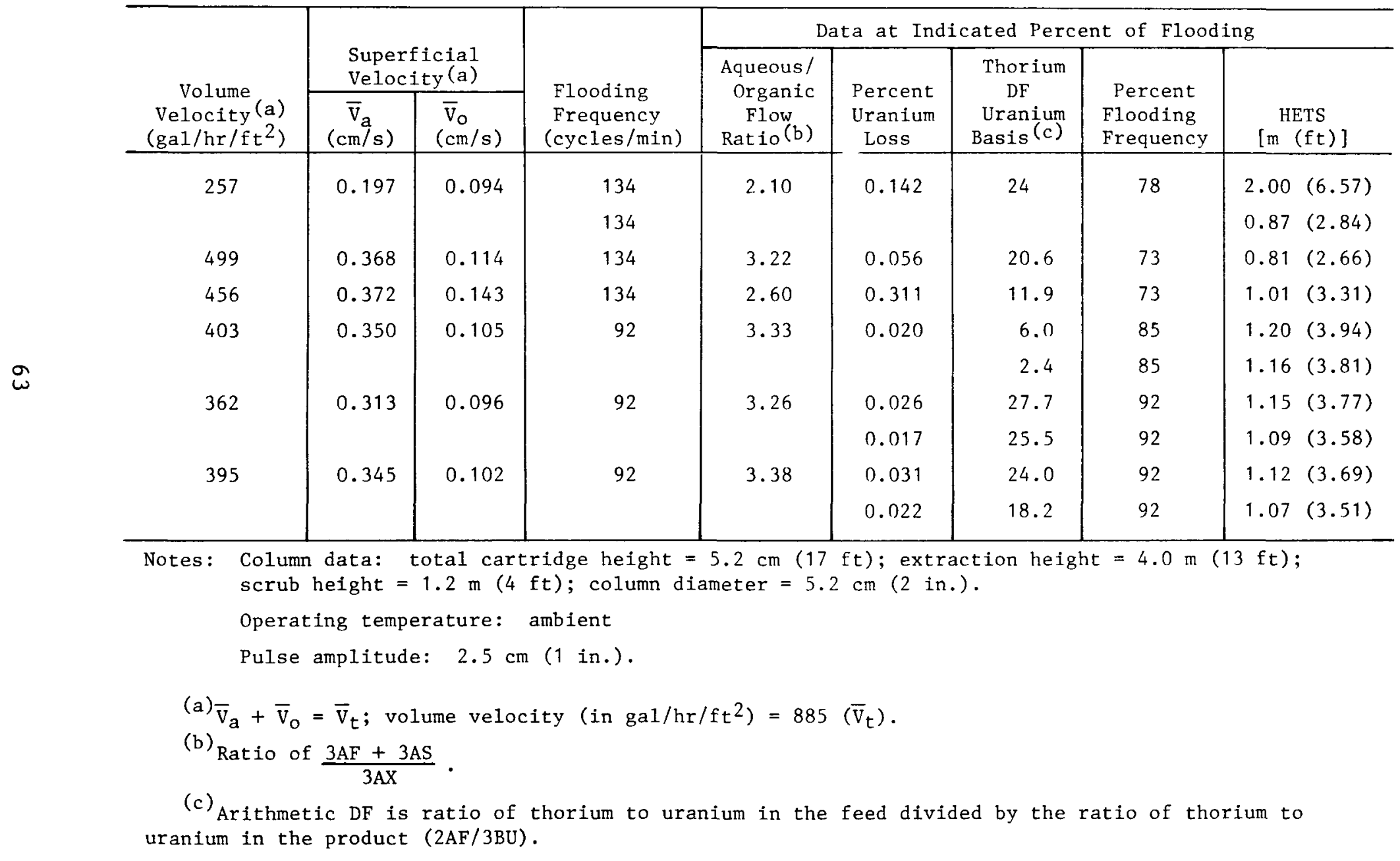


TABLE A-14

HRRF ACID-THOREX PROCESS: OPERATING DATA FOR COLUMN 3B (STRIP) (SEE FIG, 8)

\begin{tabular}{|c|c|c|c|c|c|c|c|c|c|}
\hline \multirow{3}{*}{$\begin{array}{c}\text { Volume } \\
\text { Velocity (a) } \\
\left(\mathrm{gal} / \mathrm{hr} / \mathrm{ft}^{2}\right)\end{array}$} & \multirow{2}{*}{\multicolumn{2}{|c|}{$\begin{array}{l}\text { Superficial } \\
\text { Velocity }(a)\end{array}$}} & \multirow{3}{*}{$\begin{array}{c}\text { Flooding } \\
\text { Frequency } \\
\text { (cycles/min) } \\
\end{array}$} & \multicolumn{6}{|c|}{ Data at Indicated Percent of Flooding } \\
\hline & & & & \multirow{2}{*}{$\begin{array}{l}\text { Aqueous/ } \\
\text { Organic } \\
\text { Flow } \\
\text { Ratio(b) }\end{array}$} & \multirow{2}{*}{$\begin{array}{l}\text { Percent } \\
\text { Uranium } \\
\text { Loss }\end{array}$} & \multirow{2}{*}{$\begin{array}{l}\text { Thorium } \\
\text { DF } \\
\text { Uranium } \\
\text { Basis (c) }\end{array}$} & \multirow{2}{*}{$\begin{array}{l}\text { Percent } \\
\quad \text { of } \\
\text { Flooding } \\
\text { Frequency }\end{array}$} & \multirow[b]{2}{*}{$\begin{array}{c}\text { HETS } \\
{[\mathrm{m}(\mathrm{ft})]}\end{array}$} & \multirow[b]{2}{*}{$\begin{array}{l}\text { Temp. } \\
\left({ }^{\circ} \mathrm{C}\right)\end{array}$} \\
\hline & $\begin{array}{c}\overline{\mathrm{V}}_{\mathrm{a}} \\
(\mathrm{cm} / \mathrm{s})\end{array}$ & $\begin{array}{c}\overline{\mathrm{V}}_{\mathrm{O}} \\
(\mathrm{cm} / \mathrm{s})\end{array}$ & & & & & & & \\
\hline 145 & 0.070 & 0.093 & 65 & 0.75 & 16.3 & 1.0 & 77 & $1.11(3.64)$ & 50 \\
\hline 170 & 0.077 & 0.114 & 120 & 0.54 & $2.1 \times 10^{-5}$ & & 82 & $0.65(2.13)$ & 50 \\
\hline 195 & 0.078 & 0.143 & 120 & 0.68 & $1.9 \times 10^{-5}$ & 6.4 & 82 & $0.65(2.13)$ & 50 \\
\hline \multirow[t]{2}{*}{248} & 0.099 & 0.105 & 120 & 0.94 & $1.8 \times 10^{-3}$ & & 67 & $0.87 \quad(2.85)$ & 50 \\
\hline & & & & & $1.2 \times 10^{-3}$ & & 67 & $0.87(2.85)$ & 50 \\
\hline \multirow[t]{2}{*}{182} & 0.109 & 0.096 & 120 & 1.14 & $2.8 \times 10^{-3}$ & 2.1 & 67 & $1.07(3.51)$ & 50 \\
\hline & & & & & $9.1 \times 10^{-4}$ & 1.7 & 67 & $1.07(3.51)$ & 50 \\
\hline 185 & 0.107 & 0.102 & 120 & 1.05 & $1.8 \times 10^{-3}$ & 1.1 & 89 & $1.05(3.43)$ & 50 \\
\hline
\end{tabular}

Notes: Column data: total cartridge height $=5.2 \mathrm{~m}(17 \mathrm{ft})$.

Pulse amplitude: $2.5 \mathrm{~cm}$ (1 in.).

(a) $\overline{\mathrm{V}}_{\mathrm{a}}+\overline{\mathrm{V}}_{\mathrm{o}}=\overline{\mathrm{V}}_{\mathrm{t}}$; volume velocity (in gal $\left./ \mathrm{hr} / \mathrm{ft}^{2}\right)=885\left(\overline{\mathrm{V}}_{\mathrm{t}}\right)$.

(b) Ratio of $\frac{3 \mathrm{BX}}{3 \mathrm{AX}}$.

(c) Arithmetic DF is ratio of thorium to uranium in the feed divided by the ratio of thorium to uranium in the product $(3 \mathrm{AF} / 3 \mathrm{BU})$. 
TABLE A-15

HRRF MODIFIED PUREX PROCESS: OPERATING DATA FOR

COLUMN 5A (EXTRACTION-SCRUB) (SEE FIG. 9)

\begin{tabular}{|c|c|c|c|c|c|c|c|}
\hline \multirow{3}{*}{$\begin{array}{c}\text { Volume } \\
\text { Velocity (a) } \\
\left.\text { (gal/hr/ft }{ }^{2}\right)\end{array}$} & \multirow{2}{*}{\multicolumn{2}{|c|}{$\begin{array}{l}\text { Superficial } \\
\text { Velocity }(a)\end{array}$}} & \multirow{3}{*}{$\begin{array}{l}\text { Flooding } \\
\text { Frequency } \\
\text { (cycles/min) }\end{array}$} & \multicolumn{4}{|c|}{ Data at Indicated Percent of Flooding } \\
\hline & & & & \multirow{2}{*}{$\begin{array}{c}\text { Aqueous/ } \\
\text { Organic } \\
\text { Flow } \\
\text { Ratio(b) }\end{array}$} & \multirow{2}{*}{$\begin{array}{l}\text { Percent } \\
\quad \text { of } \\
\text { Flooding } \\
\text { Frequency }\end{array}$} & \multirow{2}{*}{$\begin{array}{l}\text { Percent } \\
\text { Uranium } \\
\text { Loss }\end{array}$} & \multirow{2}{*}{$\begin{array}{l}5 \mathrm{AW} \\
\mathrm{HNO}_{3} \\
(\mathrm{M})\end{array}$} \\
\hline & $\begin{array}{c}\bar{v}_{a} \\
(\mathrm{~cm} / \mathrm{s})\end{array}$ & $\begin{array}{c}\overline{\mathrm{V}}_{\mathrm{O}} \\
(\mathrm{cm} / \mathrm{s})\end{array}$ & & & & & \\
\hline 992 & 0.70 & 0.42 & 131 & 1.675 & 67 & 0.02 & 2.13 \\
\hline 998 & 0.74 & 0.38 & 131 & 1.929 & 61 & 0.01 & 1.79 \\
\hline 995 & 0.76 & 0.37 & 131 & 2.047 & 61 & 0.01 & 1.81 \\
\hline 974 & 0.72 & 0.38 & 131 & 1.870 & 67 & 0.02 & 1.84 \\
\hline
\end{tabular}

Notes: Operating temperature: ambient.

Column data $=$ total cartridge height $=6.7 \mathrm{~m}(22 \mathrm{ft})$; extraction height

$=4.0 \mathrm{~m}(13 \mathrm{ft}) ; \operatorname{scrub}$ height $=2.8 \mathrm{~m}(9 \mathrm{ft}) ;$ column diameter $=5.1 \mathrm{~cm}$ (2 in.).

Pulse amplitude: $2.5 \mathrm{~cm}$ (1 in.).

(a) $\overline{\mathrm{V}}_{\mathrm{a}}+\overline{\mathrm{V}}_{\mathrm{O}}=\overline{\mathrm{V}}_{\mathrm{t}}$; volume velocity (in gal/hr/ft${ }^{2}$ ) $=885\left(\overline{\mathrm{V}}_{\mathrm{t}}\right)$.

(b) Ratio of $\frac{5 \mathrm{AS}+5 \mathrm{AF}}{5 \mathrm{AX}}$. 
TABLE A-16

HRRF MODIFIED PUREX PROCESS: OPERATING DATA FOR COLUMN 5B (STRIP) (SEE FIG. 9)

\begin{tabular}{|c|c|c|c|c|c|c|c|c|c|}
\hline \multirow{3}{*}{$\begin{array}{l}\text { Total } \\
\text { Cartridge } \\
\text { Height (a) } \\
{[\mathrm{m}(\mathrm{ft})]}\end{array}$} & \multirow{3}{*}{$\begin{array}{c}\text { Volume } \\
\text { Velocity (b) } \\
\left(\mathrm{gal} / \mathrm{hr} / \mathrm{ft}^{2}\right)\end{array}$} & \multirow{2}{*}{\multicolumn{2}{|c|}{$\begin{array}{l}\text { Superficial } \\
\text { Velocity (b) }\end{array}$}} & \multirow[b]{3}{*}{$\begin{array}{c}\text { Frequency } \\
\text { (cycles/min) }\end{array}$} & \multicolumn{5}{|c|}{ Data at Indicated Percent of Flooding } \\
\hline & & & & & \multirow{2}{*}{$\begin{array}{c}\text { Aqueous/ } \\
\text { Organic } \\
\text { Flow } \\
\text { Ratio (c) }\end{array}$} & \multirow{2}{*}{$\begin{array}{l}\text { Percent } \\
\quad \text { of } \\
\text { Flooding } \\
\text { Frequency }\end{array}$} & \multirow[b]{2}{*}{$\begin{array}{l}\text { HETS } \\
{[\mathrm{m}(\mathrm{ft})]}\end{array}$} & \multirow{2}{*}{$\begin{array}{l}\text { Percent } \\
\text { Uranium } \\
\text { Loss }\end{array}$} & \multirow[b]{2}{*}{$\begin{array}{l}\text { Temp. } \\
\left({ }^{\circ} \mathrm{C}\right)\end{array}$} \\
\hline & & $\begin{array}{c}\overline{\mathrm{V}}_{\mathrm{a}} \\
(\mathrm{cm} / \mathrm{s})\end{array}$ & $\begin{array}{c}\overline{\mathrm{V}}_{\mathrm{O}} \\
(\mathrm{cm} / \mathrm{s}) \\
\end{array}$ & & & & & & \\
\hline $4.6(15)$ & 316 & 0.198 & 0.159 & $73(d)$ & 1.24 & & & & 50 \\
\hline $4.6(15)$ & 258 & 0.116 & 0.176 & $73(d)$ & 0.66 & & & & 50 \\
\hline $4.6(15)$ & 302 & 0.132 & 0.209 & $73(d)$ & 0.63 & & & & 50 \\
\hline $4.6(15)$ & 283 & 0.151 & 0.170 & $70(\mathrm{~d})$ & 0.89 & & & & 51 \\
\hline $4.6(15)(e)$ & 280 & 0.135 & 0.181 & $70^{(d)}$ & 0.74 & & & & 52 \\
\hline $4.6(15)(e)$ & 324 & 0.184 & 0.182 & $70(d)$ & 1.01 & & & 0.01 & 52 \\
\hline $4.6(15)$ & 292 & 0.144 & 0.186 & $119(f)$ & 0.77 & 72 & & 0.04 & 49 \\
\hline $4.6(15)$ & 272 & 0.138 & 0.170 & $119(f)$ & 0.81 & 84 & & 0.04 & 50 \\
\hline $4.6(15)$ & 261 & 0.131 & 0.164 & $120^{(f)}$ & 0.80 & 83 & $1.26(4.13)$ & 0.002 & 50 \\
\hline $4.6(15)(e, g)$ & 748 & 0.464 & 0.383 & $119(f)$ & 1.21 & 72 & $1.63(5.36)$ & 1.05 & 50 \\
\hline
\end{tabular}

(a) Column diameter $=7.6 \mathrm{~cm}(3.0 \mathrm{in.})$.

(b) $\vec{V}_{a}+\vec{V}_{o}=\vec{V}_{t}$; volume velocity (in gal/hr/ft $\left.{ }^{2}\right)=885\left(\bar{V}_{t}\right)$.

(c) Ratio of $\frac{5 \mathrm{BX}}{5 \mathrm{AX}}$.

(d) Operating pulse frequency.

(e) DBP added to $1 \mathrm{~A}$ extraction unit during pilot plant run.

(f) Flooding frequency.

(g) Column diameter $=5.1 \mathrm{~cm}(2.0 \mathrm{in.})$ this run only. 
TABLE $\mathrm{A}-17$

HRRF MODIFIED PUREX PROCESS: OPERATING DATA FOR COLUMN 6A (EXTRACTION-SCRUB) (SEE FIG. 9)

\begin{tabular}{|c|c|c|c|c|c|c|c|}
\hline \multirow{3}{*}{$\begin{array}{c}\text { Volume } \\
\text { Velocity (a) } \\
\text { (gal/hr/ft }{ }^{2} \text { ) }\end{array}$} & \multirow{2}{*}{\multicolumn{2}{|c|}{$\begin{array}{l}\text { Superficial } \\
\text { Velocity (a) }\end{array}$}} & \multirow[b]{3}{*}{$\begin{array}{c}\begin{array}{c}\text { Frequency } \\
\text { (cycles/min) }\end{array} \\
\end{array}$} & \multicolumn{4}{|c|}{ Data at Indicated Percent of Flooding } \\
\hline & & & & \multirow{2}{*}{$\begin{array}{c}\text { Aqueous/ } \\
\text { Organic } \\
\text { Flow } \\
\text { Ratio (b) }\end{array}$} & \multirow{2}{*}{$\begin{array}{l}\text { Percent } \\
\text { of } \\
\text { Flooding } \\
\text { Frequency }\end{array}$} & \multirow{2}{*}{$\begin{array}{l}\text { Percent } \\
\text { Uranium } \\
\text { Loss } \\
\end{array}$} & \multirow{2}{*}{$\begin{array}{l}6 \mathrm{AW} \\
\mathrm{HNO} \\
(\mathrm{M}) \\
\end{array}$} \\
\hline & $\begin{array}{c}\overline{\mathrm{v}}_{\mathrm{a}} \\
(\mathrm{cm} / \mathrm{s})\end{array}$ & $\begin{array}{c}\overline{\mathrm{V}}_{\mathrm{o}} \\
(\mathrm{cm} / \mathrm{s})\end{array}$ & & & & & \\
\hline 734 & 0.584 & 0.245 & $80^{(c)}$ & 2.38 & & 0.21 & 1.36 \\
\hline 543 & 0.366 & 0.248 & $80(c)$ & 1.48 & & 0.05 & 0.91 \\
\hline 582 & 0.399 & 0.259 & $80(c)$ & 1.54 & & 0.11 & 0.93 \\
\hline 667 & 0.479 & 0.275 & $80^{(c)}$ & 1.74 & & 0.01 & 1.03 \\
\hline 621 & 0.448 & 0.264 & $80(c)$ & 1.70 & & 0.01 & 1.02 \\
\hline 733 & 0.557 & 0.271 & $80(c)$ & 2.05 & & 0.02 & 1.03 \\
\hline 563 & 0.411 & 0.227 & $103(d)$ & 1.82 & 83 & 1.5 & 1.34 \\
\hline 579 & 0.438 & 0.217 & $103^{(d)}$ & 2.02 & 77 & 0.04 & 1.18 \\
\hline 512 & 0.426 & 0.153 & $104(d)$ & 2.78 & 77 & 0.14 & 1.21 \\
\hline 793 & 0.620 & 0.277 & $103^{(d)}$ & 2.24 & 83 & 0.26 & 0.92 \\
\hline
\end{tabular}

Notes: Operating temperature: ambient.

Column data: total cartridge height $=6.7 \mathrm{~m}(22 \mathrm{ft})$; extraction height

$=4.0 \mathrm{~m}(13 \mathrm{ft})$; scrub height $=2.8 \mathrm{~m}(9 \mathrm{ft})$; column diameter $=5.1 \mathrm{~cm}$ (2 in.).

Pulse amplitude: $2.5 \mathrm{~cm}$ ( 1 in.).

(a) $\bar{V}_{a}+\bar{V}_{\mathrm{O}}=\overline{\mathrm{V}}_{\mathrm{t}}$; volume velocity (in gal/hr/ft $\left.{ }^{2}\right)=885\left(\overline{\mathrm{V}}_{\mathrm{t}}\right)$.

(b) Ratio of $\frac{6 \mathrm{AS}+6 \mathrm{AF}}{6 \mathrm{AX}}$.

(c) Operating pulse frequency.

(d) Flooding frequency. 
TABLE A-18

HRRF MODIFIED PUREX PROCESS: OPERATING DATA FOR COLUMN 6B (STRIP) (SEE FIG. 9)

\begin{tabular}{|c|c|c|c|c|c|c|c|c|}
\hline \multirow{3}{*}{$\begin{array}{l}\text { Total } \\
\text { Cartridge } \\
\text { Height }(\mathrm{a}) \\
{[\mathrm{m}(\mathrm{ft})]}\end{array}$} & \multirow{3}{*}{$\begin{array}{c}\text { Volume } \\
\text { Velocity (b) } \\
\left.\text { (gal/hr/ft }{ }^{2}\right) \\
\end{array}$} & \multirow{2}{*}{\multicolumn{2}{|c|}{$\begin{array}{l}\text { Superficial } \\
\text { Velocity (b) }\end{array}$}} & \multirow[b]{3}{*}{$\begin{array}{c}\text { Frequency } \\
\text { (cycles/min) }\end{array}$} & \multicolumn{4}{|c|}{ Data at Indicated Percent of Flooding } \\
\hline & & & & & \multirow{2}{*}{$\begin{array}{c}\text { Aqueous/ } \\
\text { Organic } \\
\text { Flow } \\
\text { Ratio }(\mathrm{c})\end{array}$} & \multirow{2}{*}{$\begin{array}{l}\text { Percent } \\
\quad \text { of } \\
\text { Flooding } \\
\text { Frequency }\end{array}$} & \multirow{2}{*}{$\begin{array}{l}\text { Percent } \\
\text { Uranium } \\
\text { Loss }\end{array}$} & \multirow[b]{2}{*}{$\begin{array}{l}\text { Temp. } \\
\left({ }^{\circ} \mathrm{C}\right)\end{array}$} \\
\hline & & $\begin{array}{c}\overline{\mathrm{V}}_{\mathrm{a}} \\
(\mathrm{cm} / \mathrm{s})\end{array}$ & $\begin{array}{c}\overline{\mathrm{V}}_{\mathrm{O}} \\
(\mathrm{cm} / \mathrm{s})\end{array}$ & & & & & \\
\hline $5.2(17)$ & 479 & 0.295 & 0.246 & $73(d)$ & 1.20 & & & 45 \\
\hline $5.2(17)$ & 494 & 0.311 & 0.247 & $73(d)$ & 1.26 & & & 45 \\
\hline $5.2(17)$ & 485 & 0.290 & 0.258 & $73(d)$ & 1.12 & & & 45 \\
\hline $5.2(17)$ & 446 & 0.229 & 0.275 & $68(d)$ & 0.83 & & & 45 \\
\hline $5.2(17)(e)$ & 434 & 0.231 & 0.259 & $68(d)$ & 0.83 & & & 45 \\
\hline $5.2(17)(\mathrm{e})$ & 448 & 0.236 & 0.270 & $68^{(d)}$ & 0.87 & & & 45 \\
\hline $5.2(17)$ & 403 & 0.230 & 0.226 & $77(f)$ & 1.02 & 94 & 0.01 & 38 \\
\hline $5.2(17)$ & 382 & 0.215 & 0.217 & $77(f)$ & 0.99 & 88 & 0.01 & 38 \\
\hline $5.2(17)$ & 332 & 0.223 & 0.153 & $79(\mathrm{f})$ & 1.45 & 86 & 0.01 & 38 \\
\hline $5.2(17)(\mathrm{e})$ & 465 & 0.249 & 0.277 & $77^{(f)}$ & 0.90 & 94 & 0.01 & 50 \\
\hline $5.2(17)(e)$ & 465 & 0.249 & 0.277 & $77(f)$ & 0.90 & 94 & 0.02 & 50 \\
\hline
\end{tabular}

(a) Column diameter $=5.1 \mathrm{~cm}$ (2 in.).

(b) $\overline{\mathrm{V}}_{\mathrm{a}}+\overline{\mathrm{V}}_{\mathrm{o}}=\overline{\mathrm{V}}_{\mathrm{t}}$; volume velocity (in gal $/ \mathrm{hr} / \mathrm{ft}^{2}$ ) $=885\left(\overline{\mathrm{V}}_{\mathrm{t}}\right)$.

(c) Ratio of $\frac{6 \mathrm{BX}}{6 \mathrm{AX}}$.

(d) Operating pulse frequency.

(e) $\mathrm{DBP}$ added to $1 \mathrm{~A}$ extraction unit during pilot plant run.

(f) Flooding frequency. 
TABLE A-19

HRRF ACID-THOREX PROCESS: OPERATING DATA FOR COLUMN 1PUX (EXTRACTION) (SEE FIG. 10)

\begin{tabular}{|c|c|c|c|c|c|}
\hline \multirow{2}{*}{$\begin{array}{c}\text { Volume } \\
\text { Velocity (a) } \\
\left.\text { (gal/hr/ft }{ }^{2}\right)\end{array}$} & \multicolumn{2}{|c|}{$\begin{array}{l}\text { Superficial } \\
\text { Velocity }(a)\end{array}$} & \multirow{2}{*}{$\begin{array}{c}\text { Flooding } \\
\text { Frequency } \\
\text { (cycles/min) }\end{array}$} & \multirow{2}{*}{$\begin{array}{l}\text { Aqueous / } \\
\text { Organic } \\
\text { Flow } \\
\text { Ratio(b) }\end{array}$} & \multirow{2}{*}{$\begin{array}{l}\text { Percent } \\
\text { Flooding } \\
\text { Frequency }\end{array}$} \\
\hline & $\begin{array}{c}\overline{\mathrm{V}}_{\mathrm{a}} \\
(\mathrm{cm} / \mathrm{s})\end{array}$ & $\begin{array}{c}\overline{\mathrm{V}}_{\mathrm{O}} \\
(\mathrm{cm} / \mathrm{s})\end{array}$ & & & \\
\hline 461 & 0.049 & 0.47 & 93 & 0.105 & 80 \\
\hline 447 & 0.055 & 0.45 & 93 & 0.122 & 80 \\
\hline 429 & 0.042 & 0.44 & 95 & 0.096 & 63 \\
\hline 492 & 0.047 & 0.51 & 90 & 0.092 & 76 \\
\hline 494 & 0.054 & 0.50 & 90 & 0.107 & 76 \\
\hline 446 & 0.051 & 0.50 & 93 & 0.995 & 75 \\
\hline 474 & 0.051 & 0.48 & 93 & 0.106 & 75 \\
\hline
\end{tabular}

Notes: Operating temperature: ambient.

Column data: total cartridge height $=5.8 \mathrm{~m}(19 \mathrm{ft})$; column diameter $=7.6 \mathrm{~cm}$ ( 3.0 in.).

Pulse amplitude $=2.5 \mathrm{~cm}$ ( 1 in.).

(a) $\bar{V}_{a}+\bar{V}_{O}=\bar{V}_{t}$; volume velocity (in gal $\left./ \mathrm{hr} / \mathrm{ft}^{2}\right)=885\left(\overline{\mathrm{V}}_{\mathrm{t}}\right)$. (b) Ratio of $\frac{1 \mathrm{PU}(\mathrm{X})}{1 \mathrm{PUS}+1 \mathrm{AX}}$. 
TABLE A-20

HRRF ACID-THOREX PROCESS: OPERATING DATA FOR COLUMN 1 PUS (SCRUB) (SEE FIG. 10)

\begin{tabular}{|c|c|c|c|c|c|c|c|}
\hline \multirow{2}{*}{$\begin{array}{c}\text { Volume } \\
\text { Velocity (a) } \\
\left(\mathrm{gal} / \mathrm{hr} / \mathrm{ft}^{2}\right)\end{array}$} & \multicolumn{2}{|c|}{$\begin{array}{l}\text { Superficial } \\
\text { Velocity(a) }\end{array}$} & \multirow{2}{*}{$\begin{array}{c}\text { Flooding } \\
\text { Frequency } \\
\text { (cycles/min) }\end{array}$} & \multirow{2}{*}{$\begin{array}{l}\text { Aqueous/ } \\
\text { Organic } \\
\text { Flow } \\
\text { Ratio(b) }\end{array}$} & \multirow{2}{*}{$\begin{array}{l}\text { Percent } \\
\text { Thorium } \\
\text { Loss }\end{array}$} & \multirow{2}{*}{$\begin{array}{l}\text { Percent } \\
\text { Flooding } \\
\text { Frequency }\end{array}$} & \multirow[b]{2}{*}{$\begin{array}{l}\text { Temp. } \\
\left({ }^{\circ} \mathrm{C}\right)\end{array}$} \\
\hline & $\begin{array}{c}\overline{\mathrm{V}}_{\mathrm{a}} \\
(\mathrm{cm} / \mathrm{s})\end{array}$ & $\begin{array}{c}\overline{\mathrm{V}}_{\mathrm{O}} \\
(\mathrm{cm} / \mathrm{s})\end{array}$ & & & & & \\
\hline 165 & 0.118 & 0.068 & 103 & 1.74 & 7.83 & 75 & 46 \\
\hline 176 & 0.141 & 0.072 & 103 & 1.95 & 8.78 & 75 & 46 \\
\hline 175 & 0.110 & 0.088 & 100 & 1.25 & 2.3 & 76 & 42 \\
\hline 191 & 0.110 & 0.096 & 97 & 1.25 & 6.8 & 78 & 42 \\
\hline 231 & 0.138 & 0.123 & 90 & 1.12 & 9.6 & 84 & 42 \\
\hline 180 & 0.102 & 0.101 & 97 & 1.02 & 1.79 & 77 & 47 \\
\hline 190 & 0.115 & 0.100 & 97 & 1.15 & 1.44 & 77 & 47 \\
\hline
\end{tabular}

Notes: Column data: total cartridge height $=5.2 \mathrm{~m}(17 \mathrm{ft})$; column diameter $=5.2 \mathrm{~cm}$ (2 in.).

Pulse amplitude $=2.5 \mathrm{~cm}$ (1 in.).

(a) $\bar{V}_{a}+\bar{V}_{o}=\bar{V}_{t}$; volume velocity (in gal $/ \mathrm{hr} / \mathrm{ft}^{2}$ ) $=885\left(\overline{\mathrm{V}}_{\mathrm{t}}\right)$.

(b) Ratio of 1PU(X) + 1PUA 
TABLE A-21

HRRF MODIFIED PUREX PROCESS: OPERATING DATA FOR CENTRIFUGAL CONTACTOR 5A (EXTRACTION)

\begin{tabular}{c|c|c}
\hline $\begin{array}{c}\text { Aqueous/ } \\
\text { Organic } \\
\text { Flow } \\
\text { Ratio }\end{array}$ & $\begin{array}{c}\text { Percent } \\
\text { Uranium } \\
\text { Loss }\end{array}$ & $\begin{array}{c}\text { Operating } \\
\text { Speed } \\
\text { (rpm) }\end{array}$ \\
\hline 1.98 & $<10^{-2}$ & 1200 \\
1.87 & $<10^{-2}$ & 1200 \\
1.54 & $<10^{-2}$ & 1200 \\
1.95 & $10^{-2}$ & 1200 \\
1.81 & $10^{-2}$ & 1200 \\
1.90 & $10^{-2}$ & 1200 \\
\hline
\end{tabular}

Notes: Flooding speed of contactor

$<500 \mathrm{rpm}$; number of contactor stages $=8$.

Operating temperature: ambient.

(a) Ratio of $\frac{5 \mathrm{AF}+5 \mathrm{AS}}{5 \mathrm{AX}}$. 
TABLE A-22

CENTRIFUGAL CONTACTOR EFFICIENCY STUDY: STREAM AND SAMPLE DATA FOR THORIUM-30\% TBP SYSTEM

\begin{tabular}{|c|c|c|c|c|c|c|c|}
\hline \multicolumn{3}{|c|}{$1 \mathrm{AF}($ Stream 1)(a) } & \multirow{2}{*}{$\begin{array}{c}\text { 1AX (Stream 2) } \\
\begin{array}{c}\text { Flow (30\% TBP) } \\
(\mathrm{ml} / \mathrm{min})\end{array}\end{array}$} & \multirow{2}{*}{$\frac{\text { 1AA (Stream 3) }}{\text { Flow }(13 \underline{\mathrm{M}} \text { HNO) }}$} & \multirow{2}{*}{ 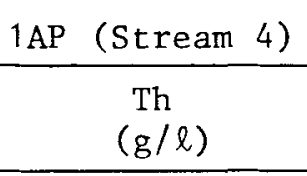 } & \multicolumn{2}{|c|}{ 1AW (Stream 5) } \\
\hline $\begin{array}{c}\text { Flow } \\
(\mathrm{ml} / \mathrm{min})\end{array}$ & $\begin{array}{l}\text { Th } \\
(\mathrm{g} / \ell)\end{array}$ & $\begin{array}{r}\mathrm{HNO}_{3} \\
(\mathrm{M})\end{array}$ & & & & $\begin{array}{l}\text { Th } \\
(g / \ell)\end{array}$ & $\begin{array}{r}\mathrm{HNO}_{3} \\
(\underline{M})\end{array}$ \\
\hline 331 & 78.39 & 1.34 & 878 & 31 & 9.84 & 0.093 & 1.71 \\
\hline 502 & 78.39 & 1.34 & 1143 & 30 & 14.8 & 0.066 & 1.34 \\
\hline 502 & 78.39 & 1.34 & 955 & 25 & 20.4 & 0.038 & 1.34 \\
\hline 321 & 78.39 & 1.34 & 528 & 25 & 36.8 & 5.45 & 1.78 \\
\hline 319 & 78.39 & 1.34 & 689 & 25 & 30.4 & 0.066 & 1.42 \\
\hline 271 & 166.71 & 1.35 & 830 & 21 & 38.4 & 0.027 & 1.70 \\
\hline 249 & 166.71 & 1.35 & 574 & 30 & 16.58 & 31.81 & 2.61 \\
\hline 285 & 166.71 & 1.35 & 710 & 26 & 120.6 & 0.482 & 2.28 \\
\hline 267 & 166.71 & 1.35 & 603 & 24 & 29.8 & 2.92 & 2.37 \\
\hline 317 & 166.71 & 1.35 & 618 & 23 & 36.8 & 20.60 & 2.20 \\
\hline
\end{tabular}

(a) See Fig. 14; 1AF stream enters stage 1; 1AA stream enters stage 6; 1AX stream enters stage 8 . 
TABLE A-23

CENTRIFUGAL CONTACTOR EFFICIENCY STUDY: STREAM AND SAMPLE DATA FOR URANIUM-30\% TBP SYSTEM

\begin{tabular}{|c|c|c|c|c|c|c|c|}
\hline \multirow{2}{*}{$\begin{array}{r}1 \mathrm{AF} \\
\begin{array}{c}\text { Flow } \\
(\mathrm{ml} / \mathrm{min})\end{array} \\
\end{array}$} & \multicolumn{2}{|c|}{$(\text { Stream } 1)^{(a)}$} & \multirow{2}{*}{$\begin{array}{c}\text { 1AX (Stream 2) } \\
\begin{array}{c}\text { F1ow }(30 \% \mathrm{TBP}) \\
(\mathrm{m} \ell / \mathrm{min})\end{array}\end{array}$} & \multicolumn{2}{|c|}{ 1AP (Stream 3) } & \multicolumn{2}{|c|}{ 1AW (Stream 4) } \\
\hline & $\begin{array}{c}U \\
(g / \ell)\end{array}$ & $\begin{array}{r}\mathrm{HNO}_{3} \\
(\underline{\mathrm{M}})\end{array}$ & & $\begin{array}{c}U \\
(\mathrm{~g} / \ell)\end{array}$ & $\begin{array}{r}\mathrm{HNO}_{3} \\
(\underline{\mathrm{M})}\end{array}$ & $\begin{array}{c}U \\
(\mathrm{~g} / \mathrm{l})\end{array}$ & $\begin{array}{r}\mathrm{HNO}_{3} \\
(\underline{M})\end{array}$ \\
\hline 372 & 10.81 & 1.71 & 328 & 11.25 & 0.231 & $<10^{-3}$ & 1.46 \\
\hline 327 & & & 314 & 10.07 & 0.36 & $<10^{-3}$ & 1.35 \\
\hline 320 & & & 273 & 12.04 & 0.36 & $<10^{-3}$ & 1.42 \\
\hline 422 & & & 282 & 14.26 & 0.23 & $<10^{-3}$ & 1.48 \\
\hline 386 & & & 207 & 20.04 & 0.27 & $<10^{-3}$ & 1.59 \\
\hline 376 & & & 153 & 28.12 & 0.20 & $<10^{-3}$ & 1.60 \\
\hline 433 & & & 87 & 37.45 & 0.20 & $<10^{-3}$ & 1.63 \\
\hline 466 & & & 99 & 46.10 & 0.16 & $<10^{-3}$ & 1.66 \\
\hline 397 & 85.39 & 2.2 & 366 & 81.76 & 0.13 & $<10^{-3}$ & 1.953 \\
\hline 518 & 85.39 & 2.2 & 401 & 96.73 & 0.13 & $<10^{-3}$ & 2.134 \\
\hline 549 & 85.39 & 2.2 & 488 & 108.25 & 0.13 & $<10^{-3}$ & 2.152 \\
\hline 604 & 85.39 & 2.2 & 384 & 104.12 & 0.11 & 13.3 & 2.152 \\
\hline 495 & 180.71 & 2.1 & 933 & 90.26 & 0.11 & $<10^{-3}$ & 1.85 \\
\hline 496 & 180.71 & 2.1 & 732 & 109.45 & 0.09 & $<10^{-3}$ & 1.65 \\
\hline 473 & 180.71 & 2.1 & 706 & 108.89 & 0.05 & $<10^{-3}$ & 2.19 \\
\hline 485 & 180.71 & 2.1 & 419 & 131.70 & 0.09 & 59.22 & 2.10 \\
\hline 504 & 180.71 & 2.1 & 732 & 115.68 & 0.07 & 8.67 & 2.08 \\
\hline$\sim 504$ & 180.71 & 2.1 & 785 & -- & -- & 2.89 & 2.01 \\
\hline
\end{tabular}

(a) See Fig. 15; 1AF stream enters stage 1; 1AA stream enters stage 6; 1 AX stream enters stage 8 . 
TABLE A-24

CENTRIFUGAL CONTACTOR EFFICIENCY STUDY:

CALCULATED THORIUM LOSS AND FLOW RATE DATA FOR 30\% TBP/NPH SYSTEM(a)

\begin{tabular}{c|c|c|c|c}
\hline $\begin{array}{c}\text { Total } \\
\text { F1ow } \\
(\ell / \mathrm{min})\end{array}$ & $\begin{array}{c}\text { Contactor } \\
\text { Operating } \\
\text { Rate (rpm) }\end{array}$ & $\begin{array}{c}\text { Aqueous to } \\
\text { Organic } \\
\text { Ratio }\end{array}$ & $\begin{array}{c}\text { Percent } \\
\text { Thorium } \\
\text { Loss }\end{array}$ & $\begin{array}{c}\text { Temp. (b) } \\
\left({ }^{\circ} \mathrm{C}\right)\end{array}$ \\
\hline 1.240 & 1200 & 0.412 & 0.12 & 24.7 \\
1.675 & 1200 & 0.465 & 0.08 & 25.6 \\
1.482 & 2000 & 0.552 & 0.05 & 26.0 \\
0.874 & 1200 & 0.655 & 6.95 & 26.7 \\
1.033 & 1200 & 0.499 & 0.08 & 26.7 \\
1.122 & 1200 & 0.352 & 0.02 & 25.0 \\
0.853 & 1200 & 0.486 & 19.08 & 25.6 \\
1.021 & 1200 & 0.438 & 0.29 & 26.0 \\
0.894 & 1200 & 0.483 & 1.75 & 27.2 \\
0.958 & 2000 & 0.550 & 12.36 & 29.4 \\
\hline
\end{tabular}

(a) Contactor used for initial extraction.

(b) Average of $1 \mathrm{AW}$ and $1 \mathrm{AP}$ temperatures. 
TABLE A-25

CENTRIFUGAL CONTACTOR EFFICIENCY STUDY:

CALCULATED URANIUM LOSS AND FLOW RATE

DATA FOR 30\% TBP/NPH SYSTEM(a)

\begin{tabular}{|c|c|c|c|}
\hline $\begin{array}{l}\text { Total } \\
\text { Flow } \\
(\ell / \text { min })\end{array}$ & $\begin{array}{c}\text { Aqueous to } \\
\text { Organic } \\
\text { Ratio }\end{array}$ & $\begin{array}{l}\text { Percent } \\
\text { Uranium } \\
\text { Loss }\end{array}$ & $\begin{array}{c}\text { Temp. (b) } \\
\left({ }^{\circ} \mathrm{C}\right)\end{array}$ \\
\hline 0.700 & 1.134 & $<10^{-2}$ & 26 \\
\hline 0.641 & 1.041 & $<10^{-2}$ & 27 \\
\hline 0.593 & 1.172 & $<10^{-2}$ & 28 \\
\hline 0.704 & 1.496 & $<10^{-2}$ & 29 \\
\hline 0.593 & 1.865 & $<10^{-2}$ & 29 \\
\hline 0.529 & 2.458 & $<10^{-2}$ & 29 \\
\hline 0.520 & 4.977 & $<10^{-2}$ & 29 \\
\hline 0.565 & 4.707 & $<10^{-2}$ & 29 \\
\hline 0.763 & 1.085 & $<10^{-2}$ & 22 \\
\hline 0.919 & 1.292 & $<10^{-2}$ & 24 \\
\hline 1.037 & 1.125 & $<10^{-2}$ & 24 \\
\hline 0.988 & 1.573 & 15.6 & 24 \\
\hline 1.428 & 0.531 & $<10^{-2}$ & 25 \\
\hline 1.228 & 0.678 & $<10^{-2}$ & 26 \\
\hline 1.179 & 0.670 & $<10^{-2}$ & 26 \\
\hline 0.904 & 1.158 & 32.7 & 26 \\
\hline 1.236 & 0.689 & 4.80 & 27 \\
\hline 1.289 & 0.642 & 1.60 & 27 \\
\hline
\end{tabular}

(a) Contactor used for initial extraction; contactor operating $\mathrm{rpm}=1200$, flooding frequency $=<500 \mathrm{rpm}$.

(b) Average of $1 \mathrm{AW}$ and $1 \mathrm{AP}$ temperatures. 
TABLE A-26

CENTRIFUGAL CONTACTOR EFFICIENCY STUDY: DATA COMPARISON FOR THORIUM-30\% TBP SYSTEM

\begin{tabular}{|c|c|c|c|c|c|c|}
\hline & \multirow{2}{*}{$\begin{array}{l}\text { Corresponding } \\
\text { Input Flow } \\
\text { Rate (a) } \\
(\mathrm{ml} / \mathrm{min})\end{array}$} & \multirow[b]{2}{*}{$\begin{array}{l}\text { Output } \\
\text { Stream }\end{array}$} & \multicolumn{2}{|c|}{ Pilot Plant Results } & \multicolumn{2}{|c|}{$\begin{array}{c}\text { SEPHIS Eight-Stage } \\
\text { Calculation }\end{array}$} \\
\hline & & & $\begin{array}{c}\text { Th } \\
(\mathrm{g} / \ell)\end{array}$ & $\begin{array}{r}\mathrm{HNO}_{3} \\
(\mathrm{M})\end{array}$ & $\begin{array}{c}\mathrm{Th} \\
(\mathrm{g} / \ell)\end{array}$ & $\begin{array}{r}\mathrm{HNO}_{3} \\
(\underline{\mathrm{M}})\end{array}$ \\
\hline \multirow[t]{2}{*}{1.} & $878(1 \mathrm{AX})$ & $1 \mathrm{AP}$ & 9.84 & -- & 29.52 & 0.26 \\
\hline & $362(1 \mathrm{AF}+1 \mathrm{AA})$ & $1 \mathrm{AW}$ & 0.093 & 1.71 & 0.01 & 1.72 \\
\hline \multirow[t]{2}{*}{2 . } & 1143 & $1 \mathrm{AP}$ & 14.8 & -- & 34.43 & 0.22 \\
\hline & 532 & $1 \mathrm{AW}$ & 0.066 & 1.34 & 0.01 & 1.52 \\
\hline \multirow[t]{2}{*}{3.} & 955 & $1 \mathrm{AP}$ & 20.4 & -- & 40.93 & 0.19 \\
\hline & 527 & $1 \mathrm{AW}$ & 0.038 & 1.34 & 0.12 & 1.56 \\
\hline \multirow[t]{2}{*}{4.} & 528 & $1 \mathrm{AP}$ & 36.8 & -- & 43.67 & 0.18 \\
\hline & 346 & $1 \mathrm{AW}$ & 5.45 & 1.78 & 5.39 & 1.92 \\
\hline \multirow[t]{2}{*}{5.} & 689 & $1 \mathrm{AP}$ & 30.4 & -- & 36.26 & 0.21 \\
\hline & 344 & $1 \mathrm{AW}$ & 0.066 & 1.42 & 0.01 & 1.76 \\
\hline \multirow[t]{2}{*}{6.} & 830 & $1 \mathrm{AP}$ & 38.4 & -- & 54.44 & 0.21 \\
\hline & 292 & $1 \mathrm{AW}$ & 0.027 & 1.70 & 0.01 & 1.60 \\
\hline \multirow[t]{2}{*}{7.} & 574 & $1 \mathrm{AP}$ & 16.58 & -- & 68.55 & 0.12 \\
\hline & 279 & $1 \mathrm{AW}$ & 31.81 & 2.61 & 6.26 & 2.36 \\
\hline \multirow[t]{2}{*}{8.} & 710 & $1 \mathrm{AP}$ & 120.6 & -- & 66.57 & 0.14 \\
\hline & 311 & $1 \mathrm{AW}$ & 0.482 & 2.28 & 0.03 & 2.01 \\
\hline \multirow[t]{2}{*}{9.} & 603 & $1 \mathrm{AP}$ & 29.8 & -- & 68.56 & 0.12 \\
\hline & 291 & $1 \mathrm{AW}$ & 2.92 & 2.37 & 9.21 & 2.07 \\
\hline \multirow[t]{2}{*}{10.} & 618 & $1 \mathrm{AP}$ & 36.8 & -- & 68.76 & 0.12 \\
\hline & 340 & $1 \mathrm{AW}$ & 20.60 & 2.20 & 30.32 & 1.92 \\
\hline
\end{tabular}

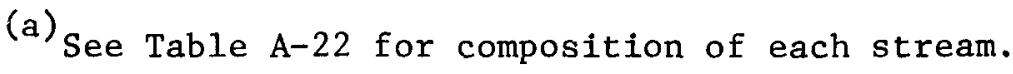


TABLE A-27

CENTRIFUGAL CONTACTOR EFFICIENCY STUDY: DATA COMPARISON FOR URANIUM-30\% TBP SYSTEM

\begin{tabular}{|c|c|c|c|c|c|}
\hline \multirow{2}{*}{$\begin{array}{l}\text { Corresponding } \\
\text { Input Stream } \\
\text { F1ow Rate (a) } \\
(\mathrm{m} \ell / \mathrm{min})\end{array}$} & \multirow[b]{2}{*}{$\begin{array}{l}\text { Output } \\
\text { Stream }\end{array}$} & \multicolumn{2}{|c|}{ Pilot Plant Results } & \multicolumn{2}{|c|}{$\begin{array}{c}\text { SEPHIS Eight-Stage } \\
\text { Calculation }\end{array}$} \\
\hline & & $\begin{array}{c}U \\
(g / \ell)\end{array}$ & $\begin{array}{r}\mathrm{HNO}_{3} \\
(\underline{\mathrm{M}})\end{array}$ & $\begin{array}{c}U \\
(g / \ell)\end{array}$ & $\begin{array}{r}\mathrm{HNO}_{3} \\
(\underline{\mathrm{M}})\end{array}$ \\
\hline 1. $401(1 \mathrm{AX})$ & $1 \mathrm{AP}$ & 96.7 & 0.13 & 105.8 & 0.09 \\
\hline $518(1 \mathrm{AF})$ & $1 \mathrm{AW}$ & $<10^{-3}$ & 2.13 & $<10^{-3}$ & 2.18 \\
\hline 488 & $1 \mathrm{AP}$ & 108.3 & 0.13 & 92.4 & 0.16 \\
\hline 549 & $1 \mathrm{AW}$ & $<10^{-3}$ & 2.15 & $<10^{-3}$ & 2.11 \\
\hline 3. 384 & $1 \mathrm{AP}$ & 104.1 & 0.11 & 107.3 & 0.08 \\
\hline 604 & $1 \mathrm{AW}$ & 13.3 & 2.15 & 14.6 & 2.19 \\
\hline 4. 933 & $1 \mathrm{AP}$ & 90.3 & 0.11 & 92.2 & 0.19 \\
\hline 495 & $1 \mathrm{AW}$ & $<10^{-3}$ & 1.85 & $<10^{-3}$ & 1.84 \\
\hline 732 & $1 \mathrm{AP}$ & 109.5 & 0.09 & 115.1 & 0.05 \\
\hline 496 & $1 \mathrm{AW}$ & $<10^{-3}$ & 1.65 & 1.90 & 2.14 \\
\hline 6. 706 & $1 \mathrm{AP}$ & 108.9 & 0.05 & 114.9 & 0.05 \\
\hline 473 & $1 \mathrm{AW}$ & $<10^{-3}$ & 2.19 & $<10^{-3}$ & 2.14 \\
\hline 7. 419 & $1 \mathrm{AP}$ & 131.7 & 0.09 & 115.1 & 0.05 \\
\hline 485 & $1 \mathrm{AW}$ & 59.2 & 2.10 & 79.3 & 2.12 \\
\hline 8. 732 & $1 \mathrm{AP}$ & 115.2 & 0.07 & 115.1 & 0.05 \\
\hline 504 & $1 \mathrm{AW}$ & 8.67 & 2.08 & 4.9 & 2.14 \\
\hline
\end{tabular}

(a) See Table A-23 for concentration of uranium and nitric acid in each input stream. 
1. Reddick, G. W., "Solvent Extraction in HTGR Reprocessing. Interim Development Report," ERDA Report GA-13835, General Atomic Company, February 1976.

2. Rainey, R. H., and J. G. Moore, "Laboratory Development of Acid Thorex Process for Recovery of Thorium Reactor Fuels," Nucl. Sci Eng. 10, 367-371 (1961).

3. "Hanford Atomic Products Operation, Purex Technical Manual," USAEC Report HW3150, Hanford Works, March 25, 1955.

4. Heath, C. A., and M. E. Spaeth, "Reprocessing Development for HTGR Fuels," ERDA Report GA-A13279, General Atomic Company, February 16, 1975.

5. Richardson, G. L., "The Effect of High Solvent Radiation Exposures on TBP Processing of Spent LMFBR Fuels," USAEC Report HEDL-TME-73-51, Hanford Engineering Development Laboratory, June 1973.

6. Benedict, G. E., "Light Water Reactor Fuel Reprocessing Program, Quarterly Progress Report for the Period Ending March 31, 1977," ERDA Report GA-A14391, General Atomic Company, Apri1 1977.

7. Wilbourn, R. G. "Safety Aspects of Solvent Nitration in HTGR Fuel Reprocessing," ERDA Report GA-A14372, General Atomic Company, June 1977.

8. "HTGR Fuel Reprocessing Facility, System Design Description for Solvent Extraction Reprocessing System," ERDA Report SDD 1.2A, Idaho National Engineering Laboratory, March 1975.

9. "Preconceptual Design and Estimate Summary for HTGR Recycle Demonstration Facility (HRDF)," Volume 1, July 1975, General Atomic Company unpublished data.

10. "Thorium Utilization Program, Quarterly Progress Report for the Period Ending February 29, 1976," ERDA Report GA-A13833, General Atomic Company, March 31, 1976.

11. "Thorium Utilization Program, Quarterly Progress Report for the Period Ending May 31, 1976," ERDA Report GA-A13949, Genera1 Atomic Company, June $30,1976$. 
12. "Thorium Utilization Program, Quarterly Progress Report for the Period Ending August 31, 1976," ERDA Report GA-A14085, General Atomic Company, September 30, 1976.

13. "Thorium Utilization Program, Quarterly Progress Report for the Period Ending November 30, 1976," ERDA Report GA-A14214, General Atomic Company, December 1976.

14. "Thorium Utilization Program, Quarter1y Progress Report for the Period Ending February 28, 1977," ERDA Report GA-A14304, Genera1 Atomic Company, March 1977.

15. "Thorium Utilization Program, Quarterly Progress Report for the Period Ending May 31, 1977," ERDA Report GA-A14441, General Atomic Company, June 1977.

16. "HTGR Fuel Recycle Program, Quarterly Progress Report for the Period Ending August 31, 1977," ERDA Report GA-A14583, General Atomic Company, September 1977.

17. "HTGR Fuel Recycle Program, Quarterly Progress Report for the Period Ending February 28, 1978," ERDA Report GA-A14878, General Atomic Company, March 1978.

18. Rainey, R. H., et al., Oak Ridge National Laboratory, "Modifications of the SEPHIS Computer Program for Calculating the Acid-Thorex Solvent Extraction System," paper presented at American Nuclear Society Meeting, San Francisco, California, November 16-21, 1975.

19. "Interim II Specification for U-233 Uranyl Nitrate Feed Solution to the Resin-Loading Process," ERDA Report ORNL-S100, Oak Ridge Nationa1 Laboratory, June 1976.

20. Abraham, L., et al., "Flowsheet Review for Production Reprocessing and Production Refabrication Requirements," November 10, 1975, General Atomic Company unpublished data. 